\section{Alll02 4835?}

NATL INST OF STANDARDS \& TECH R.I.C.

A11102483571

IU.S. access to Japanese technlcal liter
QC100.U57 NO.710 V1986 C.2 NBS-PUB-C 19
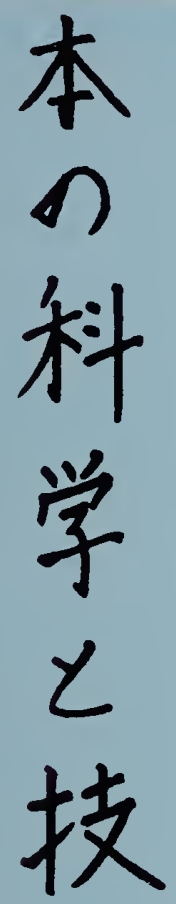

術
NBS Special Publication 710

\section{U.S. Access}

to Japanese

Technical

Literature:

Electronics

and Electrical

Engineering

Proceedings of a

Seminar Held at the

National Bureau of Standards

Gaithersburg, Maryland

June 24-25, 1985
U.S. Department of Commerce

National Bureau of Standards

$-Q C$

100

.457

No. 710

1986

C. 2 
he National Bureau of Standards ${ }^{1}$ was established by an act of Congress on March 3, 1901. The Bureau's overall goal is to strengthen and advance the nation's science and technology and facilitate their effective application for public benefit. To this end, the Bureau conducts research and provides: (1) a basis for the nation's physical measurement system, (2) scientific and technological services for industry and government, (3) a technical basis for equity in trade, and (4) technical services to promote public safety. The Bureau's technical work is performed by the National Measurement Laboratory, the National Engineering Laboratory, the Institute for Computer Sciences and Technology, and the Institute for Materials Science and Engineering.

\section{The National Measurement Laboratory}

Provides the national system of physical and chemical measurement; coordinates the system with measurement systems of other nations and furnishes essential services leading to accurate and uniform physical and chemical measurement throughout the Nation's scientific community, industry, and commerce; provides advisory and research services to other Government agencies; conducts physical and chemical research; develops, produces, and distributes Standard Reference Materials; and provides calibration services. The Laboratory consists of the following centers:
- Basic Standards ${ }^{2}$

- Radiation Research

- Chemical Physics

- Analytical Chemistry

\section{The National Engineering Laboratory}

Provides technology and technical services to the public and private sectors to address national needs and to solve national problems; conducts research in engineering and applied science in support of these efforts; builds and maintains competence in the necessary disciplines required to carry out this research and technical service; develops engineering data and measurement capabilities; provides engineering measurement traceability services; develops test methods and proposes engineering standards and code changes; develops and proposes new engineering practices; and develops and improves mechanisms to transfer results of its research to the ultimate user. The Laboratory consists of the following centers:
- Applied Mathematics

- Electronics and Electrical Engineering ${ }^{2}$

- Manufacturing Engineering

- Building Technology

- Fire Research

- Chemical Engineering ${ }^{2}$

\section{The Institute for Computer Sciences and Technology}

Condusts research and provides scientific and technical services to aid Federal agencies in the selection, acquisition, application, and use of computer technology to improve effectiveness and economy in Government operations in accordance with Public Law 89-306 (40 U.S.C. 759), relevant Executive Orders, and other directives; carries out this mission by managing the Federal Information Processing Standards Program, developing Federal ADP standards guidelines, and managing Federal participation in ADP voluntary standardization activities; provides scientific and technological advisory services and assistance to Federal agencies; and provides the technical foundation for computer-related policies of the Federal Government. The Institute consists of the following centers:
- Programming Science and Technology

- Computer Systems Engineering

\section{The Institute for Materials Science and Engineering}

Conducts research and provides measurements, data, standards, reference materials, quantitative understanding and other technical information fundamental to the processing, structure, properties and performance of materials; addresses the scientific basis for new advanced materials technologies; plans research around cross-country scientific themes such as nondestructive evaluation and phase diagram development; oversees Bureau-wide technical programs in nuclear reactor radiation research and nondestructive evaluation; and broadly disseminates generic technical information resulting from its programs. The Institute consists of the following Divisions:
- Ceramics

- Fracture and Deformation ${ }^{3}$

- Polymers

- Metallurgy

- Reactor Radiation

\footnotetext{
'Headquarters and Laboratories at Gaithersburg, MD, unless otherwise noted; mailing address Gaithersburg, MD 20899.

${ }^{2}$ Some divisions within the center are located at Boulder, CO 80303.

${ }^{3}$ Located at Boulder, CO, with some elements at Gaithersburg, MD.
} 


\section{U.S. Access}

to Japanese

Technical

ก

Literature:

科

Electronics

and Electrical

Engineering

Edited by: Edward L. Brady

Associate Director for

International Affairs

National Bureau of Standards

Gaithersburg, MD 20899

Selected Presentations Volume I

Issued January 1986

U.S. DEPARTMENT OF COMMERCE, Malcolm Baldrige, Secretary 
Library of Congress Catalog Card Number: 85-600637

National Bureau of Standards Special Publication 710

Natl. Bur. Stand. (U.S.), Spec. Publ. 710, 155 pages (Jan. 1986)

CODEN: XNBSAV

\section{U.S. Government Printing Office}

Washington: 1986

For sale by the Superintendent of Documents, U.S. Government Printing Office, Washington, DC 20402 
TABLE OF CONTENTS

Volume I

PAGE

I. FOREWORD . . . . . . . . . . . . . . . . 1

Dr. Edward L. Brady

Associate Director for

International Affairs

National Bureau of Standards

II. CHARGE TO THE SEMINAR . . . . . . . . . . . . . . 5

Dr. Ernest Ambler

Director

National Bureau of Standards

III. CONGRESSIONAL CONCERNS . . . . . . . . . . . . . 9

Honorable Doug Walgren

Chairman, Subcomittee on Science

Research and Technology

U.S. House of Representatives

IV. ROUND TABLE DISCUSSION - LIST OF PARTICIPANTS . . . . . 15

1. Ms. Maryanne Bach . . . . . . . . . . . 17 Republican Technical Consultant

House Committee on Science and Technology

2. Professor Sam Coleman .. . . . . . . . . 19

Associate Director for Research

and Program Development

North Carolina Japan Center

North Carolina University

3. Dr. Harlow Freitag . . . . . . . . . . . 21

Chaiman, Technical Activities Board, IEEE

IBM Corporation

4. Mr. Kaname Ikeda . . . . . . . . . . . . 23

Counselor for Scientific Affairs

Embassy of Japan

5. Mr. Herbert Landau . . . . . . . . . . . 25

President

Engineering Information Inc. 
6. Dr. Join P. Riganati . . . . . . . . . . . 27 Director of Systems Research Institute for Defense Analyses Supercomputing Research Center

7. Professor Richard Samuels . . . . . . . . . 31 Associate Professor Massachusetts Institute of Technology

8. Mr. Pat windham ............ . . 33 Professional Staff Member Subcomittee on Science, Technology and Space Committee on Commerce, Science \& Transportation House of Representatives

V. SUMMARY CONCLUUSIONS AND RECOMMENDATIONS . . . . . . . 35 Mr. Justin L. Bloom President Technology International, Inc.

VI. APPENDIX I - SEMINAR PROGRAM . . . . . . . . . . 47

VII. APPENDIX II - LIST OF SPEAKERS . . . . . . . . . . 51

VIII. APPENDIX III - LIST OF ATTENDEES . . . . . . . . . . 55

IX. APPENDIX IV - AN OPEN LETTER TO ATTENDEES . . . . . . 61

Volume II

VISUALS

X. TABLE OF CONTENTS 65 
FOREWORD

In his opening charge to the NBS-IEFE Seminar on U.S. Access to Japanese Technical Information, NBS Director Ermest Ambler points out how ubiquitous the products of Japanese technology have become in American society. For some types of products, Japanese technology has become the best in the world. Unless American scientists and engineers can create a mechanism for maintaining a current awareness about the new technology being developed in Japan, they will be forced into a catch-up position. Almost all Japanese scientists and engineers can, and do, read the English-language literature; few Americans can read the Japanese-language literature. The realization that this unbalanced situation must be corrected has become widespread in Government and in private sector technical communities.

In order to examine the needs of electrical and electronics engineers in some detail and to explore possible approaches to satisfy. those needs, the National Bureau of Standards and the Institute of Electrical and Electronics Engineers joined resources to hold this seminar. The participants were representatives of government, industry, and the educational commity who are aware of the importance of maintaining current knowledge of technical progress in Japan but who find themselves frustrated by language problems. Although the great majority of Japanese technical literature is written in the Japanese language, some 20 percent is published in English. How important is this 20 percent, and do Americans pay adequate attention to it? Few Americans can read Japanese; but how essential is an awareness of the content of Japanese-language literature? What practical steps can those persons who want to keep up with developments in electrical and electronics engineering take to share the effort of preparing translations, analyzing, and summarizing their technical content in order to improve access for interested Americans? How can the Federal Government, the electronics industry, and the educational community share responsibility, effort, and costs?

Following Dr. Ambler's charge to the seminar, the program featured a keynote address by Congressman Doug Walgren (D. Pennsylvania), Chaiman of the Subcommittee on Science, Research and Development, of the House of Representatives committee on Science and Technology, which has held two series of hearings on Japanese translations and American efforts to maintain awareness of Japanese developments. This talk was followed by statements by representatives of IEEE and of the American Electronics Association, presenting their viewpoints on important issues. Speakers representing the individual engineer and the educational community then discussed the needs of their communities. This was followed by a survey of the current activities of various organizations to make Japanese infomation more accessible in the United States. Then, a round table discussion, with opportunity for participation by all attendees, addressed the issues and presented recommendations for action by both the public and private sector. Finally, a summary commentary and interpretation 
was presented by Dr. Justin Bloom, former Science Counsellor at the American Embassy in Tokyo.

The Program Comnittee for this seminar consisted of Dr. Justin Bloom (formerly Science Counsellor at the American Embassy in Tokyo, now an independent consultant), Dr. Harlow Freitag (IBM Corporation, Chairman, Technical Activities Board, IEEE), Dr. John Riganati (who was at that time Chief of the Systems Components Division at NBS and is now Director of Systems Research, Institute for Defense Analyses), and the undersigned. All members of the committee contributed their broad knowledge of people and relevant activities to the development of the program. Comments of the participants indicated that the seminar achieved most of what it could have realistically been expected to accomplish. It succeeded in raising the level of awareness among the participants of the nature of the problems of Japanese literature access and translation, and introduced the complexity of these problems to at least a few people who had not previously given much thought to it. It provided an opportunity for people who are actually trying to do something practical to exchange experiences with each other and to tell a new audience about the existence of their own services. Also the meeting gave several Congressional staff members an opportunity for informal discussions with people who are deeply immersed in the situation and seek the assistance and encouragement of Congress.

In the original planning of this seminar, the decision was made not to attempt to publish a complete record of all presentations, but instead to prepare a brief volume to record the most significant statements and the final summation of Dr. Bloom. Volume 1 is the result of that decision. Volume 2 is a compilation of the visual aids used by all speakers (who used such aids). This material was assembled and prepared for reproduction through the generous volunteer assistance of Dr. Stephen Juhasz of the Southwest Research Institute in San Antonio, Texas, to whom the conference organizers and participants are deeply grateful. The conference organizers considered this to be such an important contribution to the record that we requested, and received, permission from the President of Southwest Research Institute, Dr. Martin Goland, to display the logo of SwRI on the cover.

The appendices consist of the program of the seminar, a list of speakers, a list of all attendees, and an "Open Letter to the Seminar," prepared by a group of NBS staff members, who attended the meeting and were struck by the number of statements about the difficulty of the Japanese language and how hard it is to learn. These people, on their own initiative, had organized a Japanese language training program for themselves, enlisting the participation of Japanese guest scientists and Japanese-speaking staff members. This letter points out that well-motivated technical people can, with modest effort and expenditure, learn enough technical Japanese to determine whether a Japanese-language paper is of interest to them. Then, if desirable, they can have the paper translated. We decided to include this letter as a message of optimism and encouragenent 
to people who might feel that the task of learning a useful amount of Japanese is impossibly difficult.

Edward L. Brady

Associate Director for

International Affairs

National Bureau of Standards 

CHARGE TO THE SEMINAR

\author{
Ernest Ambler \\ Director \\ National Bureau of Standards
}

It is my pleasure to open this seminar and tell you a little bit about how we decided to sponsor this along with the IEFE. I suppose those of you here really don't need to know much about the background. We all are very much aware of the success of Japanese technology in the marketplace. We only have to look at the parking lots, or the electronics stores, or the stores where they sell photographic equipment to realize that. I am sure you all follow the MITI Five-Year Plan, which lays out their determination to develop the Fifth Generation Computer, ceramic automobile engines, biotechnological processes, and so on. In addition, we read in the last Five-Year Plan of the determination of the Japanese to become more creative. That's in their own words, and what they mean is to do more basic and original research. Certainly, those of us in the Commerce Department are painfully aware of the trade imbalance between this country and Japan. We have no doubt that Japanese technology and manufacturing capability pose a very stern challenge to us. We have to admire the Japanese who are beating us at our own game, and we need to do something about it.

Well, I don't want to over-simplify this; I certainly don't want to appear alarmist because I'm not. In fact, I'm quite the opposite. Especially over the last two or three years, I've become much more confident that this country is moving in its own way, using its own political institutions, to mount an effective response. There are other aspects to the challenge, of course. It's not just the technology that has been embodied in Japanese products. Again, as a member of the Commerce Department, I'm very much aware of the attention that Secretary Baldridge and others are giving to ensure fair access to Japanese markets. This does seem to be a problem.

I don't need to mention the fine personal characteristics of the Japanese people, their intelligence, their industriousness, and above all, their educational system that trains twice as many engineers per capita as we do. There have been a lot of studies, hundreds on this particular matter, and I think we understand it pretty well. Those are aspects that we are not going to address at all today. We are going to focus on one small, but important aspect of all of this-the technical literature published by Japanese scientists and engineers. And in particular, how do we gain access to this literature. Also in particular, the question of translation and how we convert their literature to English is an extremely important aspect of this discussion.

We have decided to take a strongly focused approach in this seminar. It seems to me that for the general problem, a total global approach 
is indigestible and difficult to grasp--for example, all foreign literature, or an evaluated engineering data base. Taking a crack at the global problem by tackling a part of it is the practical way to proceed. We will start by discussing what I consider to be the most important part. So the topic today and tomorrow will be electrical and electronics engineering. I began to think about holding this seminar about a year ago, focusing it in the way I just described, so I contacted Harlow Freitag of IEFE. He agreed to join forces and cosponsor this conference to develop recommendations on practical steps that might be taken to improve U.S. access to Japanese technical literature in the fields that I mentioned.

What do we hope to accomplish in the next two days? First of all, I think we need to define the magnitude of the problem. A survey has shown that approximately 20 percent of technical literature of Japanese origin is written in English. In electrical and electronics engineering, is this 20 percent important, or the most important, or if not, what is its relative importance? I'm told that in basic physics, access to an English-language version of important research is excellent. If so, physicists' problems seem to be small. Alternatively, maybe we can assert that physicists have learned to do what perhaps electrical engineers have not. If that's true, and I'm not asserting that it is true, we need to discuss it. Why is it so? Bill Koch of the American Institute of Physics will be with us, and he will tell us about this situation as physicists see it.

Most people are really convinced that the English language availability of Japanese technical information is quite inadequate. Among those is the Honorable Doug Walgren of Pennsylvania; he is Chairman of the Subcommittee on Science, Research and Development in the House of Representatives. His subcommittee has oversight of the National Bureau of Standards, among other responsibilities, and we are fortunate in having him with us today. He will be speaking next and will give us the perception from the Hill on this subject. An official of the American Electronics Association, a major trade association in the area, will then present for us a comparative analysis of the electronics industries in the United States and Japan, particularly the different information acquisition practices in the two countries.

Next, we have on the program a spokesman for IEEE, followed by persons representing the individual professional engineer, a major research and development laboratory, and the engineering education community. All of these people will report on the issues and the problems as they see them from their own particular vantage point. And then we will have a series of reports on current activities of various organizations, govermment agencies, professional societies, and private-sector organizations. So, we have a lot of different points of view represented, and the thing that we are aiming at is to see what kind of consensus we'll build. I said earlier, in my opening remarks, that I am not an alarmist about this issue, that I did see this country mobilizing and moving on matters such as this challenge from the Japanese. 
As Director of the Bureau of Standards, I deal with a lot of different institutions. The characteristic of the United States that I am most impressed with is that ours is a very pluralistic society. I'm sure Mr. Walgren is only too painfully aware on the Hill of all the people he has to see representing different points of view. Sometimes the country appears to be made up of several million local PTA's. On the other hand, it's a very great strength because it means we are fast on our feet and people can rapidly become intimately aware of the particular problem. We have great opportunities to maneuver, but we also have a lot of checks and balances built into the system. I see this system, which could lead to total paralysis, gradually moving and building consensus in many different areas. The education area, including the cooperation between industry and universities, is one such area. So, there are a lot of points of view to be presented these next two days.

Then in our final session, we provide an opportunity for any person here to speak. Anybody who has observations or recommendations or conclusions, they are not only welcome, but they are requested to present their points of view. Again let me say, please be suspicious about global solutions; please try to be as specific as you can on this particular subject relating to electronics and electrical engineering.

Finally, to wrap up the discussions, we have asked Justin Bloom to do the wrap-up for the whole program and to present a summary of the submissions, conclusions, and recommendations that have been brought out. We are very pleased to have Justin here. Justin is an old friend of mine; I had the privilege of working with him while he was Science Counselor in Tokyo, and he is a fine person. In fact, one of the unfortunate decisions of the State Department was to reassign Justin after his five-year stint in Tokyo; they should have left him there. But of course, rotation of assignments is normal practice in the state Department.

I am looking forward to all of the presentations, and I trust that we will have a lot of discussion and that we will reach some conclusions, and that then there will be some action. I must say that I have an ulterior motive in all of this; as a physicist, I am reminded of the time of Sputnik, which some of you may be too young to remember. That's when we thought, "The Russians are coming," and there was a question of access to Russian technical literature. We mobilized very well to cover Russian physics literature, and I think Bill Koch will say something about that. Well, it was physics then and it's electrical engineering now. So, my ulterior motive is to, shall we say, encourage IEEE to tackle Japanese literature. IEFE is the greatest, the biggest, and one of the best professional organizations in the country. If we physicists, who were one tenth the number, can do it, why not the biggest professional organization in the whole United States. So this is my ulterior motive. I look forward to this seminar and I hope you all enjoy it. 
CONGRESSIONAL CONCERNS

\author{
Honorable Doug Walgren \\ Chairman, Subcommittee on Science \\ Research and Technology \\ U.S. House of Representatives
}

I certainly appreciate the opportunity to be here today to express on behalf of the public the interest that we have in the subject that has brought you to the National Bureau of Standards. We look at our institutions in this country, and we try to understand how they can serve us best. The Congress is also an institution that has to be looked at and approached with some understanding of its various roles. For our purposes today, I think it is important to approach the Congress with an appreciation of the limitations of its role in the subject of our meeting. We have deep problems in our country. I am especially aware that people from Pittsburgh have associated some of these problems with the difficulties that we have had in trade with Japan, particularly in steel. There is an immediate instinct to want a doctor to be able to make us well, and we have of ten looked to the Congress for that solution. The Congress is really not that kind of an institution, but it is a forum in which we can work with people like yourselves to develop the necessary consensus that might lead to a policy or to a constructive contribution. My point is that I don't envision the Congress charging into this problem as a knight on a white horse with a magic sword. We have to work together with public opinion and with interested parties in this country in order to develop even the minimal support necessary to take a joint action.

Our interest in this problem on behalf of the public is obvious, if only because our economy is in a precarious position at this point. The onset of deficits in the $\$ 200$ billion range which, according to the WASHINGTON POST this morning, can be anticipated for the foreseeable future regardless of the wishful thinking of many people, puts us in a very, very dicy position. If you start out with an economy operating with a $\$ 200$ billion deficit and something bad happens, you drive the economic imbalances to levels where they have never been before. We don't know what would happen if we had a series of events that increased unemployment by 4 percent. By most people's estimates that would add $\$ 150-200$ billion additional to the deficit, and that would create such a degree of uncertainty in our economy that we really would not know what would happen.

The point of that is that we have to be vigilant on every front to try to moderate the imbalances that we are confronted with and to make the most of any available strength in our economic prospects. Certainly the higher technological areas of our economy have to be pursued, and that leads us right to the contribution that the exchange of information with a country as advanced as Japan can make to our own development. Japan has excelled particularly in the manufacturing technologies, and we must realize that we can benefit from some very close contact with the society that produced the technique:s that have been so successful in manufacturing technology. Although I think we know how to mates the degree of automation 
in Japanese production, we have not fully integrated such techniques into our economy, and therefore, we are missing those benefits.

It's also true that in the long run, Japan and the United States are expected to be the two major economic players in the world. It is my understanding that already over half of our trade goes to the Asian portion of the globe, and consequently, such trade is a major factor in our economy. Therefore, both for the short-run and the long-run health of this world economy, we in the United States have to take every opportunity to develop our international trade with all geographic areas. I do think that the world economic situation remains explosive; changes are taking place so rapidly that we must develop new ways to adjust to them. When we take the historical view, it is apparent that the real world that we encounter in this generation is largely the result of economic forces. We must learn how to overcome our present inability to resolve the international trade differences that we have and learn how to achieve mutual benefit in such trade.

Certainly in the long run, the United States and Japan have inseparable common interests in developing the new technologies together. The rapidity of change of our present circumstances makes it even more important for Japan and the United States to have an intimate and cooperative relationship, one that would surmount cultural barriers at least in the sense that the United States culture could become sensitized to the Japanese culture, and to the extent that a significant number of Americans would become able to appreciate the Japanese language and be able to operate within the Japanese culture. We need a cultural osmosis between the two societies in both directions. Up to now, we on the political side feel that the osmosis has been generally one way. We know that the Japanese, after World War II, have made an incredible effort to open up their society by importing ideas and technologies from abroad. The numbers of touring groups of Japanese specialists through United States facilities has been overwhelming and continual. That is simply a reflection of their understanding, perhaps driven by their own limitations as an island nation, that they must compete commercially in the international market or else they will not develop to their fullest potential. In this country, we have enjoyed many luxuries that have enabled us, I am afraid, to not make the most out of our potential. We have not had wars fought on our soll; we have had a basically complete resource base so that we were not dependent internationally on others, and generally we have had such a job market in this country that we have not been forced to reach out to other cultures in order to make the most of ourselves economically. That is a luxury that we will obviously not be able to afford in the future. We must work very hard now to try to develop the U.S. capability to reach out to other cultures and markets.

Most industrial societies seem to believe that they are not doing as well as they should, and when we consider the number of imported automobiles in the United States and the loss of the consumer electronics industry and other industries from our manufacturing base, we have an emotional defense reaction. This defense reaction goes something like this--Well, we really remain better than they are, and they have just imitated our 
technologies and worked on them to the degree that they somehow or other are successful with them, but we really still don't have anything to learn from that other society.

A fair view, in my opinion, is that we certainly have much to learn, despite our real strengths. Our society is very strong in original basic research; we are still generating new knowledge and pushing the leading edges of technology as well. At the same time, we certainly should be on guard against any sense of arrogance on our part, any thought that somehow or other we can do these things without regard to what is happening about us. That is dangerous.

When we look at the efforts that have been made, or perhaps I should say the lack of efforts that have been made, in accessing Japanese technical literature, we cannot escape the thought that we are complacent. The behavior of our culture implies that we really needn't look abroad, that no matter what happens over there, somehow or other we'1l ultimately do just fine here. That simply is not the case. We find when we look for American efforts to access Japanese technical literature that our society makes not much of an effort at all.

We don't have much of an information policy in this country; our policy is not to have a policy. With such a policy, we find that although we have had bits and pieces of support for translation services, there has not been a fundamental appreciation of their importance. Therefore, when budget cuts came along, even those small efforts were lost. For example, the National Science Foundation used to have substantial support for translation efforts that led to steady support in the 50's and the 60 's for some of the major scientific areas. Now, after the National Science Foundation has gone through ten years of essentially frozen budgets, we find that that support no longer exists. Let us look at the support for Japanese translation, which I understand was mostly focused by the NSF through a major 1ibrary in Chicago. If you compare the efforts in 1970 and in 1980, you find that while the volume of relevant information exploded during those years, or at least multiplied by four, our actual effort when measured in constant dollars atrophied by a factor of two. The result of it is that ten years later you find yourself essentially making one-eighth the effort that was being made in 1970, and you wonder if that really means that we are headed in the right direction. I think clearly we are not, and somehow or other we have to understand that, we must find a policy that will provide ongoing support for important efforts 1 ike that.

As I say, we don't like policies, and we particularly don't like information policies set by Government, but we have to have some kind of policy because having none will serve us badly. We have to identify the sources to which we want to go. We have to somehow or other put in place the effort to translate those sources, and we have to have some kind of dissemination system that makes sense to us. We can talk about whether the National Technical Information Service (NTIS) document sale system is the method of dissemination that we like or whether we prefer regional libraries where literature is accessible. The point is--we ought to talk 
about it, but our experience on the Congressional level is that there really is not very much talking at all. In fact, when you raise the subject with the private sector, you find that the major firms are by and large relatively satisfied with their access, and those that have made an effort on their own to create a flow of information to themselves, then do not want to share that flow with anybody else. Because of the nature of our private sector, access will probably not be generalized in the national interest. If the major companies have what they consider to be a satisfactory flow of information, that will reduce the drive to broaden the system enough so that the society as a whole can benefit. Even though it may be in the short-run interest of a Westinghouse or a General Electric to have a certain flow of information just to themselves for proprietary purposes, that limited access is not in the national interest. We must develop the exchange further.

In the Congress, we are interested in this, and a year ago, we had a set of hearings somewhat similar to your symposium here. We are having a further hearing this week, which also will be a forum for people who have an interest in this area to make a statement that will be available to others and hopefully will result in building a consensus for activism in this area. Last year the Congress suggested that we put $\$ 750,000$ into a fund that would be used to try to take some initial steps in this area. Well, how far does $\$ 750,000$ go? Not really very far. It couldn't do much more than just cause somebody to think about the area. It's also true that executive agencies of the Government are not doing very much now. The best estimate that we could make was that the Department of Commerce had what amounted to one man in Tokyo with a budget of $\$ 120,000$ a year--one attache in Tokyo who came from Japanese industry, and his job was to access the range of Japanese technical literature for the United States. Now, his salary is about $\$ 60,000$, and I'm sure that you consume the other $\$ 60,000$ just in the process of transferring anything back to this country, let alone disseminating it to interested persons here. So you can see that our effort in the past has been nearly nonexistent.

I hope that out of your conference will come a recognition of the problem and some suggestions as to what we might constructively do about it. It isn't a problem that would be amenable to crash, large-scale, federal financing, but certainly it will require detailed, continuing interest by entities in our society that stand to benefit from development of this area. Out of your seminar and these hearings that we are having on the Hill and other communications systems that we have--magazine articles and the like--we hope there will come a consensus that we ought to be encouraging activity in this area. As we get our feet wet, maybe we'11 appreciate the benefits of it even more. Well, our Science and Technology Committee will have observers here for the two days of your meeting, and they will be coming back to us to encapsulate and transfer those proceedings and those discussions into our institutional memory in the House of Representatives.

We look forward to your trying to push us in the direction that you think we ought to go. The largest unappreciated asset this country has, I 
think, is the built-in response that the Congress has to individuals in this society. One of the greatest threats to our system is that we feel everything is so big that we as individuals don't matter anymore. We in the Congress hope that you do not feel that way. I would like to invite you to know and work with the Congress as an institution capable of responding to you and your sensitivities as an individual. When you go back to the various parts of the country and the various roles that you come from, I hope that you will work with your individual Congressional representative and also with the relevant committee to tell them what you think should be done. I would like to offer myself as present chairman of the Subcommittee on Science, Research and Technology to develop the response that conferences such as this conclude are the directions we ought to be going.

I appreciate very much the opportunity to come here and just to share my general thoughts with you, and I look forward to your guidance in the future. If the past is any prologue, there is no question that our society can respond effectively in a way that is constructive for both Japan and the United States in international trade and in the development of a peaceful world. We must learn how to make the international economy of the future run as well as we have the right to hope that it can run. Thank you very much for listening to me and good luck in your conference. 



\section{ROUND TABLE DISCUSSION}

\section{List of Participants}

1. Ms. Maryanne Bach Republican Technical Consultant House Committee on Science and Technology 2319 Rayburn House Office Building Washington, DC 20515

2. Professor Samuel K. Coleman Associate Director for Research and Program Development North Carolina Japan Center North Carolina University Raleigh, North Carolina 27695

3. Dr. Harlow Freitag

Chairman, Technical Activities Board, IEEE IBM Corporation White Plains, NY 10604

4. Mr. Kaname Ikeda Counselor for Scientific Affairs Embassy of Japan 2520 Massachusetts Avenue Washington, DC 20008

5. Mr. Herbert Landau President, Engineering Information Inc. 345 East 47 th Street New York, NY 10017

6. Dr. John P. Riganati Director of Systems Research Institute for Defense Analyses Supercomputing Research Center 4380 Forbes Boulevard Lanham, MD 20706

7. Professor Richard Samuels Associate Professor Massachusetts Institute of Technology Cambridge, MA 02139

8. Mr. Pat Windham Professional Staff Member Subcommittee on Science, Technology and Space committee on Commerce, Science \& Transportation House of Representatives 2321 Rayburn House Office Building Washington, DC 20515 


\section{Ms. Maryanne Bach}

I would like to proceed in a way that may be most helpful, and that is to explain the most recent action taken by the House committee on Science and Technology in addressing the question of availability of Japanese translations. Coincidentally and very fortuitously, the committee is holding hearings in Washington tomorrow and Thursday during which we will continue the effort of the last four years in assessing what type of information has been available; what will be available; what is the proper role of the Federal Government; how does the Federal Govermment determine what that proper role is; what actions are being taken by the professional societies; what is industry doing to obtain more information; and how is the educational community of the nation responding.

For your information, I can tell you who will be testifying. Several of those people you have heard from over the course of the last two days will appear. We have asked Mrs. Pat Hubbard (American Electronics Association), Dr. Gene Strull (Westinghouse Defense and Electronic Systems Center), Dr. Edward Daub (University of Wisconsin-Madison), Mr. George Rogers (Intelligence Community Staff), Dr. Joseph Caponio (NTIS), Mr. Charles Horner (Department of State), Mr. George Mu (Office of Japan, Department of Conmerce), and Dr. Emest Ambler (NBS). As I said, this is a continuing effort that we have addressed through the form of a congressional hearing, but I would also like to remind the audience that this is not the only way for congress to gain its information. We have discovered and been educated on one subject particularly--that is, industrial firms to some extent have felt uncomfortable in coming forward and speaking about their progress and their means of gaining information. They may have proprietary reasons for such, or the reason may be that upper management in corporations is not as willing as scientists and researchers further down the company structure to converse with Congress on what programs would be appropriate. But I would say very candidly that congress, particularly the House Science and Technology committee, has from a number of different directions become aware that there is a federal role of some kind, which we are struggling to identify, in providing technical information to the scientists, whether they be in the industrial sector or in the research sector.

Some of you may not be familiar with why we would be involved, why we are concerned about it, and what previous knowledge base we would have to help us determine that some progress is needed. I would just name a couple of issues that we have had to address from a national perspective that have led us to discuss specifically Japanese translation and technical information availability. We have been faced in the nation with a question of the capacity and preparedness of our educational system. How well are we preparing our students at pre-college, at college, and at graduate levels to meet the needs of our technological society and the industrial future for which this educated manpower base will be needed? We have, as far back as the mid-1970's and up through the $80^{\prime} \mathrm{s}$, been comparing the educational system of the United States with those of our strongest competitors. 
We have found that through the years, we are not as proficient in the technical and scientific areas, as well as in foreign languages. We are still providing courses in the Romance languages, but we are not providing instruction in those specific languages that are used by our strongest competitors. So our educational preparedness is a topic of major concern.

Because of the Congressional role in overseeing the major governmental technical agencies and because of congress' responsibility for reflecting the concerms and interest of their constituents, congress must deal with questions of national security, of scientific freedom, of competitive position, and of technology transfer.

There is a national concern about the results of American-financed research, whether it be througin the Federal laboratories or through Federal agencies that support competitive grants programs in our universities. We are concerned that there is a gap between the transfer of $R \& D$ information into American companies and the eventual progress in the use of that information for commercialization. In some instances, that may be working well with larger companies, but certainly there is concern that middle-size companies and small businesses and the general health and well-being of our American companies are not getting maximum benefit from the resources we are putting into basic science.

The question has also arisen of the imbalance in our graduate programs between American students and foreign students, and why it is that fewer American students seem to be attracted into technical fields. What can we do to attract American students into those areas, those programs, that seem to be most promising in terms of employment? congress also has an interest in computer and information security, and in the previous Congress, our comittee was instrumental in the R\&D antitrust legislation that now allows American corporations to come together and collaborate for the purposes of R\&D. That purpose, in and of itself, was not to be considered a violation of antitrust law. We are looking into the reason for doing that, and hesitancy on the part of the judicial system to tamper with antitrust laws brought about the fact that in many instances and in many industries, we are forced at this point to collectively share our resources. I don't want to take up any more time but I could go on as to the interests of congress. I would also point out to the audience that we do need encouragement as to why we should pursue the proper Federal role, and in some instances, there are voids in that type of encouragement. 


\section{Professor Sam Coleman}

As someone from a university, I would like to give my own personal overview of the goings on of the last couple of days. I won't need. to sumarize too much, but one thing I will note is that perhaps one of the concrete accomplishments of this meeting will be to have given a final definition to the value of English-language materials on Japanese science and technology from a number of perspectives. If I were to summarize that, I think I would summarize it using one of Woody Allen's older jokes. Two elderly ladies are at a Catskills resort, and they are complaining about the food. One of them said, "This food is terrible." The other one said, "Yes, and there's not enough of it."

We've seen some very good efforts, but I think we all agree that they are piecemeal, and they are uncoordinated. Now, Ernest Ambler said in charging the participants here that we should be suspicious of global solutions. If he means by that large-scale, star-studded, quick fixes, I would agree. But, I think we should also be suspicious of part answers--half-baked, part solutions, magic bullets, fast promises. It takes long-term planning. As soon as we get into the whole issue of increasing the number of Americans in scientific and technical specialties who possess Japanese language knowledge and knowledge of how Japan ticks, we are talking about a long-term proposition. We have repeatedly talked about this issue in terms of America's competitive stance, about our need to think in terms of biting the bullet and making investments with a long-term view. We know things aren't going to happen overnight, but I think that bears repeating. Occasionally, people will talk about market forces taking care of this. I am very skeptical of that approach. We deal at our school with students in the sciences and engineering, and we also teach Japanese to people in places like IBM and Northern Telecom. And the people in industry who are the most concermed about Japan are the ones who have the least time to learn the language. I find it hard to believe that any 25- or 30-year old IBM engineer first exposed to all that is going on in Japan, or anyone at any other electronics-related firm, is going to say, "I should have learned the language; I'm going to drop out now and catch up." I just don't think it will happen on the kind of scale that we need.

Another thing, too, is that when I say investment, I mean investment in dollars. If we take a look at the various activities that have gone on, the various attempts that have been described in this meeting, the ones that have made it, and that are going to make it, are those that have solid backing. Clark Johnson discussed the beautiful efforts of the Magnetics Association; they were backed by good financing-- $\$ 300,000$, I believe. The American Institute of Physics Russian translation system that eventually got on its feet had 10 years of NSF support before it was self-sufficient. Or we could look at the problems of a system when it depends on immediate market backing, like the experiences of Engineering Information Incorporated. 
We may be feeling frustrated after these repeated discussions about scientific and technical information needs. As a next step, we should, as a self-conscious group, line up our constituencies. Who are the people that really stand to gain the most from a concerted, long-term, sophisticated, comprehensive effort? And to do that, perhaps we can set up two continua, if you will. (I'm a social scientist; we always love to categorize and set up continua.).

One continuum joins basic sciences and the applications areas of the technologies. On one end, in the basic sciences, we work with the ideal of free and open sharing of information. Thus we have a synergistic effect; we get more bang for the buck. We aren't reinventing the wheel. Of course, on the other end of the continuum, we have competition. We have people who are putting in their own money and aren't obligated to tell anybody else about what they are doing, and they would be fools if they did. Those constituencies are different, and I think, for Japanese scientific and technical information, we are going to be offering them different things. And we must. Thus we will also have a short-run, long-run continuum. Perhaps with an analysis like that we can start to get a grasp of who our fellow supporters will be on what's going to be a long and difficult road ahead.

Since I came from a university, at times I may be accused of getting into what the Japanese call "selling your own product (temae miso)." Nevertheless I think there are some important virtues there. We have a lot of expertise; we have a lot of interest in and knowledge of what's going on in Japan. The issue of scanning capacity has come up before. The term was coined by MIT's Eleanor Westney in the Congressional hearings last year, and it meant "knowing what to pick out to translate." There's a lot of expertise in the university that can help tell people just what is worth translating and what isn't. These same university people, if they are rewarded by a system of good technical translation, will get more professional development and will be better consultants to industry. They will in turn encourage their students to study the Japanese language. As you can see, these are mutually reinforcing arrows. Once you get a comprehensive system going, you've got these mutually reinforcing arrows, and if you do it right, it's going to look like Custer's last stand.

For that kind of system, though, concerted support is necessary, and I believe that support will have to come from the Federal Government. 


\section{Dr. Harlow Freitag}

While this is billed as an NBS/IEEE Seminar, I really must take the privilege of the floor to thant: Dr. Brady, because he really put this whole program together. I think it is an outstanding program, and I think we all should thank him for getting everybody who participated here to come.

Let me say that I wish that the interest in translating Japanese technical literature into English was a fraction as great outside this room as it is inside this room. We wouldn't have a problem; we wouldn't all be here. I'm really struck by the indifference in the technical community regarding Japanese translation and the access to Japanese literature in general. It's hard for me to understand it, but it's there and I think we all have to be proselytisers and carry back our feelings. We must explain to people that this is a serious problem, and that people are going to eat our lunch if we are not careful. I think the need for translation was confirmed at this seminar. The number of engineers in Japan equals that of the United States, and they are putting out just as much technical information. If we don't have access to it, we certainly are the losers.

I think that a second and much more pernicious problem is the question of how much of the literature is, shall we say, deliberately withheld, or deliberately published at a later time scale in English than it is published in Japanese. Although we have no quantitative information on this point, as a technologist, I hate to see loaded dice, and I think that this is really a question of loading the dice in an unfair way.

The problem of reading the Japanese literature is just the same in some ways as reading English literature. Reading English literature is the subset of our problem in reading Japanese literature, that is English literature is voluminous and you can't read it all; you can't read a small fraction of it. So, we have the problem compounded, because now we have this voluminous Japanese literature. How do we read that? How do we even get it into English so that we can read it? So, one problem is that there is a lot of stuff that will be translated that we will have access to that we are just not interested in. But we can't let that deter us from going ahead and making this information available. Costs are high; translators are not available. The translators must be technically competent. You cannot have just any old person that understands Japanese do the translation. That is going to be a serious problem, and here is, I think, the first place that the Government can help--they can help establish centers of excellence in Japanese translation, but especially in Japanese technical information.

You people that are interested in establishing translation programs, I'd like you all to succeed. But I'm afraid if there are too many of you, it will spread the available interest and the available money around, and we'll all flounder. I'd rather see just one venture 
dominate, so that it can be financially successful. But, that's not our business to control.

The professional societies, I think, are willing; the IEEE, for example, is willing to do a lot more in this area. The problem with professional societies is that they can't deal with the start-up costs. The start-up costs are much too high. They can deal with the incremental costs of publishing information on a page-by-page basis, but they can't handle the costs in getting started. So, that is something that maybe the Govermment can help in.

I would love to see Clark Johnson's publication be wildly successful, but he still is just publishing his first copy and we don't know just exactly how many people are to take that. I would lilse to point out that the IEEE pubiishes something we call an all-transactions package, which is all of IEEE's periodical publications, numbering somewhere near 50, and something slightly over a thousand libraries take that package. They get it at a discount over what it would cost if they bought them all individually. That's a thousand libraries all over the world. Now, Johnson's journal is a translation of Japanese magnetic information; how many, what fraction of that thousand libraries is going to be interested. The only real market for such a volume would seem to be in a library. I just don't know that it is going to make it financially.

My last point is that maybe this is finally the time to get computers in the act in a big way. If we had a central repository of translations, including issues of Japanese literature, and machinery to perform, there are all kinds of exquisite searches that can now be performed on data bases of this type. You can do any kind of logical connective request; you can scan every word in the document and 1ook for two words that appear in the same document, and get all that information out. This may be the way to somehow hamess the flood of information, and at the same time, amortize the cost of providing it over a very large number of users so that they pay a very modest amount of money for each access. 


\section{Mr. Kaname Ikeda}

I have been asked to say something provocative to the audience. I understand the topic of the seminar, and I could recognize the needs for improvement. It is needed to have good access to Japanese literature. As for myself, I have been long engaged in the Govermment in the field of research and development. I'm originally from the Science and Technology Agency. My personal experience is in this agency. I did find some difficulty in the past, on our side, in approaching the U.S. technological information in the field of nuclear and space technology, sometimes due to some needs for security or propriety. So, I think my personal experience was that we also have some difficulty in getting access to U.S. literature.

I think when we talk about access to Japanese literature, or to scientific or technological information, this issue should be categorized into two areas. One is finding or locating appropriate material. Another one is the processing of the material or information. I think in the latter one, the Japanese language might be a bit difficult, I agree. But, I would like to elaborate to the first one. I have to say that Japanese society is called sometimes information heaven. This means too easy access to any kind of information. We don't have any legislative control of information, like you have in the United States. So we do have really a kind of heaven in this sense. Nowadays, as far as high-tech--so-called high-technology is concerned--my personal opinion is that information is flowing, really flowing, but not all of it in the form of literature. This is quite different from the situation you have here in the United States. Of course, I should say there should be some difference in culture and society. This is largely due to our differences in society and social structure. People in industries have an in-house network for flow of information, so this flow is not so well documented. That is why you could observe a voluminous flow of information, but you will find it will be difficult to have access to the flow. Maybe I'm a little bit exaggerating to some extent.

In Japan, information is not always priced, but is almost always free. That's why Govermment is very encouraging to industries to share the information and to reach consensus. Especially to say, we need to have better cooperation. I could mention here the Japanese project for the so-called Fifth Generation Computer. This is the kind of project that we really solicit the people in industry to share the information to avoid duplication and to have correct image in those areas.

Sometimes through meetings, conferences, or direct involvement in joint projects, people in industries share information so many times there is no need for documentation or preparation for literature. So, I do believe there should be incentives for the people concerned in preparing the document or literature. When they need to cooperate, for instance, between the United States and Japan, they usually do work to have literature or a document. Also I think there should be 
some effort on the side of the users--in this case, the people in the United States--to visit or to have occasion to share exchange of opinions.

This is my feeling and to this point I should direct attention to the comment made by Mr. Konishi this morning. There was a comment that a governmental report is political. This sometimes may be but I think government reports might be useful as evidence of consensus and they could give you a clue of some interest to various information behind an authorized report. And I should say additionally government offices are open to inquiry. As I mentioned before, we do not have any legislative restrictions on infomation. Only people in industries do have some proprietary difficulty. And if you people in the United States do have some proficiency in Japanese you could feel free-quite free-in visiting almost any offices in the govermment or in the industries. There would be no discrimination between Japanese and the people from the United States. 


\section{Mr. Herbert Landau}

Well, when Ed asked me to serve on the panel, he implied that it would be good to be a bit of an agent provocateur, and I won't let him down. I think back to some of the basic training I received as a systems analyst. I was taught that before you can solve your problems you have to define what they are. I find that after the first day and a half I'm even more confused than I was after the past three years in defining what the problem is regarding this issue of getting access to Japanese technical literature, or even the broader issue of getting access to Japanese technical information. I think everybody here would say, yes, there is a problem, but I'm not sure everybody would agree on what it is. Based on many of the solutions or approaches posed, there seems to be a variety of problems, or perhaps different facets of the same problem. I think this is one of the basic reasons why the United States hasn't made significant progress in this area. We aren't sure what the problem is and why we want the information and what we would do with it. I think there are economic problems regarding U.S-Japanese relations as evidenced by the fact that one has to but look outside and see how many of our automobiles or television sets or cameras are Japanese. Economically, Japan is beating the pants off of us in many areas that were originally U.S. turf. So I don't think the problem is very well perceived or very well defined. My own organization is equally at fault here.

Current efforts, as a result, are not correctly addressing the problem, whether it is an issue of translation or access to the literature or access to an individual. Current efforts are piecemeal, uncoordinated, somewhat duplicative, parochial, ill funded in general, and I think definitely not very cost effective. Perhaps a good place to start would be to define exactly what the problems are before we develop alternate solutions and analyze them on a cost benefit basis. One way would be to have some blue ribbon group of objective, representative experts in technology, information, and international relations look at the real needs, define what these needs are, and then define current efforts to address these needs. They would have to examine the full spectrum of government, academe, industry, not-for-profit, and professional societies' efforts; identify what gaps exist that should be filled; and assess what resources we have, as a nation, to fill them. It is a very large task, but I think it's going to cost us a lot more if we continue on a piecemeal effort in terms of dollars, and in terms of, eventually, our national economic pride.

Being positive rather than negative, I think the United States has the resources to gain access to Japanese technical information, or, for that matter, the technical information of any other country if we put our mind to it. But, I think these resources need to be channeled. We need seed money to get them going, because there will be some false starts, and indeed, a lot of these efforts will have very low payoff, or very long-range payoff. It will not be commercially viable, to begin with at least. I think there is a role for everyone, 
and indeed the commercial sector, as they have shown today, will jump in where they think they can make a profit, because that is their purpose. However, I think there are a lot of areas, a lot of basic foundation efforts, that are not profitable and will never be. They will require some effort on behalf of Government, which agency I am not sure, but perhaps the National Science Foundation would be a good place to start.

What we are seeing here is a tip of an iceberg, of a broad, growing, and a continuing national need to recognize the fact that other countries are going to do significant scientific and engineering work that the United States must be made aware of. Since it is a broad national problem, it does require a comprehensive plan of action at the national level. While I don't have any ready solutions, I think that together we must find what the problem really is, look at the alternate solutions, and then pick the best ones for the United States as a whole. 


\section{Dr. John P. Riganati}

I would like to comment in three areas briefly. First is background: my particular interest and association with this field; the second is structure; and the third is some considerations on how to proceed.

My involvement in this kind of activity goes back to January of 1982 when Dick Samuels, seated at my left, and Eugene Skolnikoff of the MIT Japan program organized a conference similar to this one on Japanese scientific and technical information in these United States. The thrust of that conference was to discuss the kind of information we had or did not have. I had recently been a panelist at the first Fifth Generation Conference in Tokyo in the fall of 1981, and presumably I had some timely information to share of the kind that wasn't yet available in the United States except through the news media (whose coverage is generally inadequate in detail and of a different emphasis than technical people would typically like) .

At the conference, I found surprising emphasis on the fact that there is very little organized structure in the United States to put technical information at the hands of scientists and engineers, who would like to have it when it is not available in English. Some things that have come out of that conference were discussed today. Unfortunately, none of them, from my perspective, have built any considerable momentum at the present time. One was a study financed and supported by NBS, MCC, and AFIPS which we referred to under the National Academy of Sciences program. Second was an effort that Bill Finan at the Department of Commerce put together which has led to the program that Tony Amstrong of SAIC described, and third, very indirectly, was a set of Congressional hearings motivated as much by the Congressional staff as by outside influences. My current question as I look at the field in this conference today is, "Over the last three and a half years, has any momentum built or not?" We still have a small group of people on the inside who perceive a need in a number of the areas that Herb Landau just mentioned, but at the same time we don't have a process in the United States that has been able to put together, following the "rules of the game," a set of procedures that solve the many problems that exist. The "rules of the game" concern items such as return on investment, which involve different organizational responses in the United States than in Japan, as you are all well aware, or they involve same kind of a plebiscite where the would-be users of information make their views known. One example of the latter is our Congressional process. Both of those appear to be absent right now, and yet a number of us, those in the room in particular, have the feeling that there really is something that ought to be done.

By way of structure, two points of view come to mind. First is the notion of the top-down structure, which one immediately thinks of, especially in the Washington area. That was my initial input into the system in the spring of 1982. I called several offices in the National Science Foundation, reasoning that a technical problem of 
this kind should be of interest to NSF. I found that NSF was certainly interested in the technology of Japan, but really didn't have a structure at that time to deal with availability of information. Things have changed to some extent, but certainly not in a large enough way to make a sionificant difference; NSF does not have a structure to support foreign language information, per se. I called the Department of Education and found they were interested in the Japanese as a culture, as a language--typically filed in many of our universities as you know in the fine arts department, but they were not interested particularly in the technology component. So here we have an overlap of the interests of two key agencies, and in the overlap, instead of the concentrated resources of those two agencies, we find that each avoids the area. The top-down solution fram the federal agencies themselves has not worked over this period of time to any significant extent.

Industry has taken some role; Pat Hubbard has told us about the efforts of the American Electronics Association. Professional societies have taken some roles; university short courses have been developed. But none of them have gotten to the point where anyone in this room can see that the problem is solved or is on a good path for a total solution.

The top-down approach must be continued, in my opinion, but we haven't seen any evidence in the last three and a half years that the rules of the game will allow anything different to happen in the next few years other than what we have seen in the past.

If we look at a bottom-up path, I was surprised to learn earlier this year that here at NBS we have a Japanese language course going on at lunch time. This course was organized by a number of scientists and engineers who felt the need for access to this kind of information. One enterprising person simply put a notice on one of our bulletin boards saying, "Wanted: an instructor and students for a course." We have many Japanese-speaking technical staff at NBS. One of them volunteered to teach the course; others volunteered to be participants, and they're off and running. What organizations could do is encourage that kind of entrepreneurial effort within agencies, within corporations, by giving the motivated scientists and engineers flexibility to express their interests and perhaps some equipment in the way of word processors or Kanji processing equipment that they can experiment with. My view is that this is more along the lines of what has worked in other places in the United States. In the long-term, a good solution might be a broad, overall treatment that uses both the top-down and the bottom-up view.

Briefly, on considerations on how to proceed, we are talking about access to information--information that obviously involves the translation of all types of material. It involves access to closely held information of the kind that's available in principle. For example, if the proceedings of this workshop were typed and made avai.lable, they could be widely circulated. They won't be. They will be circulated on a very small scale. That's closely held information, 
but in principle, open information. There is an enormous amount of that extremely important information available in Japan, as the JTECH process discovered in its recently completed panels (I participated in the panels on computer technology). More importantly, perhaps though, is language knowledge sufficient to allow joint research by colleagues in Japan and the United States working together, particularly on in-country scientific experiments. NBS and NTT have a joint agreement to pursue programs of mutual interest, and a few of those are under way right now. Hopefully, those will increase and a number of other organizations will do the same.

The challenge as I see it is to use the top-down structure, certainly spearheaded by Congress, to tabulate the appropriate actions. But we should resist the urge to prioritize them and basically let many wild flowers grow, as they can only grow in the United States, and to encourage the entrepreneurial activity that is key to the way we proceed here. It's necessary to recognize that the rules of the game in the United States are stacked against an area like this developing rapidly, because it has neither the demand from the would-be users who don't appreciate the kind of information that is available, nor the obvious return on investment that would enable the venture capital approach to work in a successful way. We have a number of experiments going on now as you have heard. University Microfilms and perhaps others may experiment in a different end of the spectrum. I am hopeful. On the other hand, the evidence of the last few years doesn't allow me as a user to expect that I will see great change in the next few years. I think it is incumbent upon those of us in the room here and the small circle that we can influence to realize the nature of the problem, to be evangelists for the field, and to constantly keep information problems in the minds of our colleagues, both our peers and certainly those in the organizational structure here in washington, whom we reach. 


\section{Professor Richard Samuels}

It is not an accident that I agree with almost everybody on this panel in large measure, because we are what John has just described-evangelists. I think self-consciously we see ourselves as such. one thing I won't do, though I agree with Sam Coleman, I won't dare quote Woody Allen for you.

Let us start by just stepping back a touch from specific solutions and try to put the problem in the perspective of public policy. We Americans have reached a sort of collective recognition that the Japanese have very effectively harvested for an extended period of time American science and technology. I think that yesterday someone said that there were about a thousand Japanese researchers in American universities. I think that number is off by about an order of magnitude, although I don't have the figures.

The question in policy terms is; so what, what do you want to do about that? What I want to suggest is that there are two possible things one might do about that--one disturbing and the other a much more positive response. The more disturbing one is the solution Mr. Ikeda referred to earlier, which is to make it more difficult for Japanese to have access to American science and technology, shutting down and confirming Japan's worst fears that the United States will retaliate to the commercial challenge of Japan by making it difficult or impossible for Japanese to have access, the information blockade, etc. And we have seen stirrings of that. We've seen it in the defense areas, and we've seen it in professional meetings. I think that that is enormously disturbing, counter productive, and wrong.

Instead I think what we can do is to take initiatives of the kinds we have been dancing around for the last two days to try to make what has been historically a one-way flow of assimilation into a two-way flow of communication between Japan and the United States. That is a long-term solution, because it involves substantial investment in the most key resource of all that we have been discussing--that is people, individuals, a generation or more of American scientists and engineers who have a knowledge about and research experience in Japan. At MIT, as at N. C. State, we have been active in doing exactly that. We have been sending 8 to 10 MJT trained engineers and scientists per year to work in Japanese government and university laboratories, and to the central research labs of industry. We have found Japan is open; there are more offers to take our students than we have students ready to go. We require two years of language training and that is why the numbers are so limited. This kind of approach, while not an immediate answer, is I think the only answer that you can really wrap your arms around.

Now to follow up on something that John said, and to really underline it, there is very much a sense of deja vu that one must have in coming to this meeting. This is really the third iteration of the same meeting. There are 20 or 30 persons of this audience, who I think have 
participated in at least one of the other, and in some cases, both of the other gatherings--the Endicott House meeting that John referred to in January of 1982 that was funded by NTIS and by the State Department and the Wilson Center Meeting that Ron Morse and I organized in February of this year. We have been talking to ourselves, we have been evangelizing, but I also observe a very positive note, that there is a collective coming of age in all of this. There is a much broader representation of people who are actively doing things in this area. There is a broad consensus on what needs to be done. In listening to Herb Landau, and to John and to Jack Schwartz yesterday. I could hear Marvin Denikoff, who at the MIT meeting three years ago identified precisely the same set of things that needs to be done, the needs assessment, the need for information centers, more training, copyright issues, blue ribbon panels, the role of NSF. There is a sense that we are continuing to talk about the same thing and that we are agreeing on what needs to be done, but that we're not necessarily, as John points out, making rapid progress.

However, there is also an emerging list of what has been done, and that is what I wanted to say was most encouraging. That private firms-for example, Motorola and MCC who came here three years ago and were table thumping--are now coming to meetings like this, sharing their experiences and saying, "Yeah, you know we need to do more in this area." The AFA programs, their publications, their fellowship program in Japan, sending students to work in labs, university programs like the one at NYU, at the Japan Center North Carolina State, Ed Daub's and Bob Bird's program at Wisconsin, and the textbook project--these are all new things. our program recently received half a million dollars from the Star Foundation in New York to send students to Japan, and all of that is very encouraging.

We still have problems. First of all I have already identified the major problem. We are talking to ourselves. In some sense we might as well be a professional association, and we oughtn't be. Congressional hearings are being held, now running through a second round. I don't think that necessarily means progress; it means hearings are being held. It's simply not clear where the locus of initiative lies now, or even agreement on where it should lie between public and private sector.

I would end by just suggesting one step for Congress to consider--to require that Fulbright programs, which historically have been only aimed at arts and humanities, and social science, should support science and engineering research abroad. The Department of Education, which has historically done that as well, should support programs in applied Japanese studies. We need more support for programs in applied Japanese studies. We don't need more clones of ourselves. That is not the business we ought to be in. We need to create new kinds of expertjse and I think this is not a Japanese problem. It is distinctly an American problem. I think we are all convinced that we need to find a solution to it. 
8. Mr. Pat Windham

I have just jotted down a note on the Fulbright idea.

I thought I would take just a couple of minutes and tell you first there is interest in what you are doing. And there is interest in the issue that you have spent so much time on. I might briefly focus on a recent Senate bill, based on some earlier House work from last year, that is now before our committee, recently introduced by Mr. Baucus of Montana and Mr. Rockefeller of West Virginia. The bill would have the Secretary of Commerce spend some more money--one of our ways of trying to deal with things--to try to improve the availability of at least the govermment-collected information and, perhaps, do more to augment what the Government is now doing. We are the first to admit that this is an early step; both the House and the Senate are trying to grapple with what for us is a relatively new, but we agree an important, issue.

I might mention the motives behind some of this; it won't surprise you. The amount of frustration, concern, anxiety that is now present in at least the United States Senate is incredible. We are facing a trade deficit that is scaring us more each day. For a while it looked like it was just our basic industries that were in trouble. Now, if we read BUSINESS WEEK the last couple of months talking about the high-tech crisis, we are watching the semiconductor industry, one of our great flagship high-tech industries, in real trouble. We all know there are several reasons behind it. There is a high American dollar which is at least in large part the result of our own Congressional budget deficit, and there is an enormous amount of work going on in that. We'll see whether it leads to anything.

There is genuine frustration with what is at least perceived to be some barriers, either legal or cultural, to American business entering Japan. But by the same token, there is an incredible feeling about getting our own house in order. That is Senator Baucus's term, who, as I say, is the prime sponsor of this bill. We know that we as a Government and as a country, have to get our own act together to deal with markets that are different than our own. And also, we have to realize that we are not the only actors around. We benefit from learning from Japan which is now the third highest spending country in the world I think, on R\&D, a real leader. We need to break out of our own cultural shell and begin to learn from others as they have quite legitimately learned from us. Our bill is only a start; as I say, it was based on the hearings that Mr. Walgren held last year that Maryanne was so involved with. We are going to try and pursue it some in the senate this year. There is real interest in this kind of thing.

By the same token, we need to hear from you all, and not just on details about the programs of work, but also about whether there is indeed a need for more Federal action in this area and what kind. 
I would really echo Maryanne's point, which is that while you may criticize, and John made a good point about this, the fact is that congress runs on a sort of plebescite basis where we have to listen to other people; that is in fact the way we do business.

It is very hard, in this day and age particularly, for anybody in Congress to say, hey, this is something that is needed, unless there is business support out there, some specific ideas from the business community, from the technical community, and from the acadenic community about what would be the best direction to go.

So, what I wanted to say in summary is, we are hearing you. We share a lot of your concerns; these bills are starting to get more attention in Congress, but we need to hear from you about what you think is the most valuable way to go. We also need you to get your friends and neighbors to write in and begin to build a little more political support for what you think are the best ways to go. 


\title{
SUMMARY COITCIUSIONS AND RECOMMENDATIONS
}

\author{
Justin I. Bloom \\ President \\ Tecinnology International, Inc.
}

The three previous conferences or seminars that have been held on this subject--the MIT Conference, the Wilson Center conference, and in fact, the 1984 Congressional hearings--were for audiences that were more limited than this one. That is, they did not include people who might become novitiates in this business, people who did not have a long exposure to or interest in Japanese technical information, the problems of accessing it, and the resources available for doing so. Therefore, my own personal feeling is that this conference is the first opportunity to address a larger body. We have been partially successful in accomplishing this in that perhaps half of the audience consists of people that we wouldn't have icientified in the past as being part of this "old-boy network" that has been referred to a number of times.

Dr. Ambler's original concept for this seminar included limiting the scope to electrical engineering and electronics engineering. This was a logical view, and it was immediately accepted by the program cormittee, but I thinj it has now become clear that the system, if I can identify it as such, for making Japanese scientific and technical information available does not structure itself well along narrow technical disciplines, and it has proven to be difficult for us to pick out electrical engineering and electronics engineering from the general science and technology arena for the purposes of this seminar. In essence, there are a few trees in the forest, because science and technology is such a big field. Therefore, as a consequence of this, we have lost some opportunities that are generally applicable, and at the same time, we have covered some generalities that are indeed applicable to aspects of science and technology other than the ones that were identified by Dr. Ambler.

The seminar must be identified as one that has offered a sampler of what is going on in Japanese science and technology and how to access it. It could not be comprehensive and authoritative in covering the entirety of the field because there isn't enough time, and I doubt if any audience could maintain an interest long enough to hear all there is to be said. Furthermore, we have had to select, by some stochastic process, those people who spoke. We could not have representatives of the entire electronics industry in the United States speak here, nor could we ask every purveyor of technical information to give his ideas of what is being done and what should be done. So, for these reasons, please recognize that there is a limitation to the amount of information that has been transferred to you.

Let me give you a couple of examples of this. There are a very large number of Japanese firms that offer technical information services to foreigners--let me say Americans to restrict it--for a fee, and 
there are very large numbers of English-language publications covering various aspects of Japanese science and technology which we have not discussed at all during this seminar. To mention only one of these, one that I read every week trying to keep up with what is happening in Japan, is the JAPAN ECONOMIC JOURNAL. I expect that most Japanologists look at this since it is published in English and is supposed to be a digest of the daily NIHON KEIZAT SHINBUN, the Japan economic newspaper equivalent to the WALI STREET JOURNAL. This English-language weekly provides relatively good coverage of what is happening in science and technology in Japan, as well as, more broadly, economics and business. So as a part of a general attempt to be literate in this area, people should read documents like this to keep up with what is happening, because, if anything, Japan is a very dynamic country. Great changes are occurring all the time, and it is necessary to follow Japan on a current basis as best as one can. The American literature, such as the American news magazines, in my opinion, do a very poor job of this, and they cannot be depended upon to be good sources of information on daily occurrences in Japan.

Another example of an information source that wasn't mentioned is a publication of the Office of Naval Research that appears quarterly and is prepared by the Tokyo ONR. It is called the ONR SCIENTIFIC BULUETIN, and although it is not exclusively devoted to Japan, most of the articles in it are concerned with Japanese science and technology, and it is a pretty good journal. It is unrefereed and cannot be cited in the scientific literature, but it is still a good source of information on relatively recent technical events in Japan. It has about a sixmonth lag time between the writing of the articles and their appearance in published form. I want to use these examples to demonstrate that you have to be careful in searching out all the sources of literature that are of interest to you, and I fully support Don Brown's point made in the question-and-answer period concerning how you find out about all these sources. This in itself is a major task that several people have struggled with. I repeat what was said in the last round table that General Motors has spent a great deal of effort to prepare such a compendium. It is already out of date. I understand it is being updated, but it is the kind of thing that will require updating just as the National Diet Library Compendium is out of date. It only comes out once every five years, as I recall; you need more current listings of information sources.

By the way, the ONR BULJETIN is sent free of charge to a subscription list of about 8,000 American scientists and engineers, contrary to the policies followed by some of the other DOD agencies. I trust that the Congress will not look unkindly on the free distribution of this report. It serves a useful purpose and, in my frame of reference, should be distributed free of charge for the benefit of the American scientific public.

This brings me to my first conclusion and recommendation and that is that as far as I know there is no complete compilation of all such sources of information published in English. I was pleased to hear 
that Mitsubishi Research may have something along this line. This grows out of the relationship that Mitsubishi Research has with JETRO, the Japan External Trade Organization which is part of the Ministry of International Trade and Industry. This will be a service, as I understand it, that will be offered for a fee by JETRO. This service is known as TECHNOMART, and it is new. I know very little about it. Mr. Yamaguchi from JETRO was here yesterday; I don't see him this afternoon. I was hoping that he would explain more about that new development in the context of all the other new developments that we have heard about in the past two days.

A mechanism for trying to get at this business of knowing what is available in the literature and how to get it has stymied us for a number of years. At that first seminar at MIT's Endicott House, I proposed that we form a new professional society in the United States based on the strong interest of some people in Japanese scientific and technical information. One of the functions of such a society could be to maintain the compilation or to act as a clearinghouse for translations and to do a number of the other activities that have been proposed here. Nothing ever came of that, I think mostly because Japanese scientific and technical information is not really a discipline in itself and, therefore, doesn't form a good basis for a professional society. I think I could get an argument going on that, partly based on what was said in the later hours of today, but for the moment, I haven't seen anybody, including myself, step up to volunteer to form a professional society based on a common interest in Japanese technical information.

One concern that remains with me in this regard is that scientific and technical information is not just one kind of information, such as refereed articles in the national and international serial periodicals and technical reports disseminated by NTIS. There are many other kinds of information that bear on this subject that are important, including science and technology policy trends in Japan or books published in Japan which try to forecast technical innovation. We have said nothing about this kind of material during this seminar. Then there are market research reports that are limited in distribution to the clients who have financed them and many other categories of information. Managers and executives need one kind of information; scientists and engineers, another. In this respect, I find that Herman Baron's Japanese Technical Information Service proposal to be a refreshing and an encouraging one, since it will try to cover the interface between science and technology and the rest of the world, the business and econamic world. Presumably it will have some inputs from the Japanese culture as well, since all of these things bear on the progress of science and technology. There seems to be essentially a unanimity of opinion among the experts that many more Americans than at present should be studying the Japanese language, particularly for the purpose of facilitating the transfer of information. However, this applies equally well to other fields again, such as economics, management, and politics. When I was in Japan two weeks ago, I heard a startling statistic given in a formal, public presentation at the Tsukuba Science 
Expo being held there now. I know it is wrong, but it shows you how nisinformation can spread around in this regard. This presentation stated that there were one million Americans studying Japanese at this time. Intuitively I know that this can't be true, and quantitatively I know that it is not true after hearing Dr. Thompson's presentation this morning. So, we have to make sure we understand how many Americans are studying Japanese and what their motivations are.

At the Wilson Center Conference, we learned that only about 400 Americans who are scientists or engineers are studying Japanese in the United States. Even that number sounded large to me, since I have great difficulty in identifying native Americans who are truly competent in scientific and technical Japanese. In the past, I have had the chance of pointing out, and I take this opportunity to repeat my own opinion, that the serious professional study of Japanese is not for everyone. I don't think we should mislead ourselves on that point. It should be undertaken only by those who are committed essentially to a lifelong interest in Japan, and in fact, the Japanese people and the Japanese culture. I can't imagine putting effort into language training of the type required without being dedicated to essentially a lifelong commitment to studying Japan and perhaps specializing in Japanese science and technology. This is not an easy task, and although a few other people in this audience--Dick Samuels, Sam Coleman, and others-are fluent in Japanese, they have to be considered the small minority of people who are particularly adept at learning the language. As I say, it is not for everyone. Americans historically have not proven to be good students of foreign languages generally speaking.

One point of information that I think I feel supported in by Sam Coleman's remark is that it is not clear that the amount of information that is available in English from Japan is being fully exploited. Certainly, this should be determined before or while efforts are being made to expand translation capabilities. I don't number myself among those who think that the Japanese may backslide into publishing less in English in the future than they have in the past. In fact, I think they will publish more, because it is also the matter of national policy in Japan to increase international understanding of Japan and to increase international cooperation in science and technology. At least one way of doing that is to make more information available in English in the future than has been done in the past. Of course, all this is predicated on the assumption that we are not going to impose restrictions on access by Japanese to the American unclassified scientific and technical literature. This would be particularly bad if Japan were singled out in this regard against all other foreign countries on the basis of its economic successes. My own observations indicate that there is an increasing number of journals and other kinds of publications appearing in English in Japan. In fact, even the publications of the Japanese Govermment are now becoming more available in English, either through quick translations of documents, such as white papers on science and technology--important for those interested in science policy--or even, for example, Dr. Ikeda's home agency's relatively new publication, SCIENCE AND TECHNOLOGY IN JAPAN, which is a quarterly 
publication available in English and obviously intended for foreign dissemination, not for domestic consumption.

I should also note that another indication of a trend is the fact that the monthly progress reports of ICOT, the fifth generation computer project team in Japan, are published in English. That's as timely as one can get, I think, in having the English-language documentation available on $R$ \& $D$ in Japan for one of the most interesting and perhaps controversial projects going on in that country.

Still, I don't want to harangue you on this point, but I want to make sure that people understand that there is an increasing amount of information available from Japan in English. Another indicator of this is a new, very sophisticated, scientific journal, entitled CONTROL THEORY AND ADVANCED TECHNOLOGY. This is published by a private company. I cannot tell you at the moment whether the articles are refereed, but the editorial board consists of international personalities in the field of control theory. The English in this journal is close to being perfect. My guess is that we won't see more than a thousand copies sold worldwide in such a narrow field, so it is obviously not a moneymaker. It is intended, I think, to improve Japan's technical image in the world.

Another rationale for believing that the Japanese will continue to publish in English is that I don't believe that they will throw over the millions of man-years of effort that they have spent in learning English as a second language, just for the purpose of making some point about the internal quality of Japanese research. The English-speaking capability of the Japanese is just now approaching the point of real fluency, and considering that they depend on international trade for survival, I fully believe that they will continue to use and to expand their use of English in the scientific and technical fields.

The other part of this problem is one I can be accused of harping on, but it was alluded to during the course of the past two days, and that is the supply and demand situation that is involved here. I think all of us say that there is a need for the information, but we haven't been able to demonstrate that there is a demand for the information. There is a real difference in the semantics of the two words. We know that the demand for the proposed Engineering Information Service was not there for whatever reason. It remains to be seen whether the demand for Herman Baron's JTIS is there, and we all hope that it's there. In fact, we should all--as somebody said-proselyte for a successful venture in this area, because intuitively we know that the United States should look abroad for developments in science and technology and to use all sources of information that are available. If the supply side of the equation continues to evolve and the demand side does not, then I have serious worries about the recurrence or the perpetuation of the infamous NIH syndrome. Even Dr. Ambler's warnings in this regard might go unheard. This is another point on which we need to fix our attention as we try to proceed with what should be done next. 
What I would like to do now is to quickly run through my notes of the various sessions to see what we learned or did not learn from them.

From Congressman Walgren, who has been, I think, the single most interested Member of Congress on this subject, we heard again of his strong comitment to increasing the flow of Japanese scientific and technical information to the United States. I in no way question his dedication, but I should point out that the $\$ 750,000$ which his subcomittee requested in the Fiscal Year 1985 budget was reduced to zero by the end of the budget process.

From Clark Johnson of the IEEE, we heard that the Magnetics Society will translate and publish all Japanese papers on magnetics, but we have to recognize that this is a small and highly specialized field. He also noted that the IEEE publishes less on Japan than the American Physical Society does, although my recollection is that the IFEE is the largest professional society in the world. Yet it has no real service for translating and publishing information from Japan.

The American Electronics Association, represented by Pat Hill Hubbard, is performing a pioneer task by sponsoring language education through total immersion in the language for a handful of young engineering students from American universities. However, even this is not fully supported by AEA's 2700 member companies, either in principle or in cash. Pat did not mention that the costs of assigning these young scientists to working environments in Japan are borne largely by the Japanese companies. They are not sponsored by American companies. Pat and I have discussed this, and she fully agrees with me on this point and she will emphasize this point in her testimony before Congress. If we can compare this situation with Japan, we would find that Japanese companies fully support financially the assignment of some of their young employees to graduate schools in the United States. One of the reasons for this, in addition to being exposed to high quality science and technology, is to improve their language capabilities. To repeat, their expenses are paid for by Japanese companies, not by American universities or other organizations.

Motorola, represented here by Bob Gonzalez and Mauro Walker, has a large financial investment in facilities and manpower in Japan. We learned that Motorola is just now getting involved with a program for acquiring Japanese scientific and technical information. It does not try to teach. Japanese to its American employees, although it fully recognizes the importance of Japanese scientific and technical information at the strategic corporate level. It relies to a large extent in the United States on English language publications already available.

Jan Vardaman of MCC showed how this new joint venture in R \& D, a really new approach for the United States and still not fully tested, is trying to keep up with Japanese developments. She stressed that language capability was the most important tool of all, but seemed to suspect that the Japanese were withholding information from outsiders. This view was supported by a number of other speakers during the conference. I 
would like to see some evidence, more than just suspicion, presented on this before I make up my own mind as to whether this is the case since I have never experienced it myself in my many years in Japan. What's more, I think we have to separate out the problem of proprietary information from general information, since all private companies withhold proprietary information from other countries and from their domestic competitors. That is not a Japanese trait, that is a universal one. We have to be very careful, I think, if we want to maintain good relations and to have a wholesome way of acquiring information to avoid recriminations of the sort that can't be proven, or at least haven't been proven yet, to my knowledge.

Professor Jack Schwartz of NYU, in representing the academic community, pointed out the failure of computer scientists in the United States to follow the foreign literature in the belief that nothing new could be learned from other countries. He didn't mention, but I think that many of you know, that NYU has embarked on a Japanese language training program, not particularly limited to science and technology, which now has over 60 students enrolled. Susan Goldman is present in the conference, and she is in charge of that program. She is a fluent speaker of Japanese.

Jack suggested that Federal Govermment financial support was needed in this whole process of acquiring information and proposed that the National Bureau of Standards be the vehicle for expanding U.S. acquisition of technical information from Japan. I endorse this and suggest or recommend further that a joint NBS/NTIS relationship be established that would take advantage of the great technical competency that resides at the Bureau of Standards and the competency in information gathering and dissemination that exists at NTIS. They are both in the Department of Commerce, and it just seems logical that this would be an easy kind of venture to arrange. I know I will get some static from people here by suggesting that a proposal for support of such a venture come from the Department of commerce, having worked its way up from the two subordinate groups. From there, the proposal should go to the Administration and then the Congress through the regular budget channel. To be successful, this kind of proposal must have the strong support of the Administration. On the other hand, I don't think that the International Trade Administration of the Department of Commerce is a particularly good place to look for funds for this kind of activity, because I feel it is so heavily involved with current trade issues, and an issue today may not be an issue tomorrow. Funding can dry up very quickly in a situation like that. I am convinced that NBS and NTIS will be around and on a smooth, steady course for a long time to come.

Jack Schwartz also stressed that academic scientists work in a different: time frame than do industrial scientists and engineers, or even management types. I deduce from this that translations or English-language publications from Japan may be particularly useful to the academic sector, as distinguished from the industrial sector, in that the information doesn't have to be quite as timely. That is, scientific information typically has a longer ingestion time than does industrial information. I may be deducing something here that is not warranted. 
Bill Koch of the American Institute of Physics outlined possible future actions by the American Institute of Physics to improve access to Japanese physics information. These actions are mostly general in nature and intended to improve the climate for transferring information rather than being designed as specific devices for increasing the flow.

It is distressing for me to hear from Steve Yau of the American Federation of Information Processing Societies that none of the eleven-member societies are engaged in the translation of Japanese journals. This may be the same syndrome that was described by Jack Schwartz--that the people in the computer or information processing field believe they have nothing to learn from the Japanese.

My friend, Mr. Osada of Mitsubishi Research, who represented the Japan Information Center for Science and Technology (JICST), described efforts that are being made to bring the JICST on-line information system to the United States in English form. I think this service is already being provided in Korea and other countries in East Asia in the Japanese language, so the break has already been made in providing the service outside of Japan. The big problem remaining for JICST will be the conversion of its data base to good English. Pricing information for this service is not yet available. NTIS will act as the agent for JICST in providing the JICST data base to Americans. This will be another test of the true demand for Japanese technical information in the United States.

Dr. Herbert Landau, the president of Engineering Information, gave us a remarkably frank and useful statement concerning the failure of his organization to win financial support from large American corporations for an on-line service designed to abstract one thousand of the best Japanese engineering journals. Each of us will have his or her own ideas about why this occurred and about how to forestall a repetition in the future.

Dave Shonyo, who represented NIIS at this conference, is also a member of that "old-boy networls" that we had been discussing. This time he caused me some heartburn when I learned that NTIS did not have the capability to translate or evaluate reports that it received in the Japanese language. I had hoped that NIIS had already been able to move beyond that point, but I also understand his problem, and I hope you do also. NTIS operates on the basis of revenues received from the sale of its services. It rarely, if ever, receives appropriations from the congress. Therefore, it can't do anything very radical. It can't suddenly increase its services because it has no money available to pay for those services. This chicken-and-egg situation is, I think, a bad one. I hope in some way, perhaps through the Congressional staff people who have been here or through other means, that another look could be taken at this arrangement. For more than ten years, NTIS has survived on the basis of revenues alone. That to me means a very uncertain life for this agency when it might well be--in conjunction with NBS--an important agency in rapidly 
increasing the transfer of Japanese technical information to the United States. It has the contacts in Japan. All the government agencies in Japan know NITS and its representatives. NTIS has a permanent representative in Tokyo as well as Mitsubishi Research Institute. The mechanism or the climate is correct for an expanded NTIS role, except for money.

I noted with interest George Mu's report on the completion of the four technical projects covered under the JTECH program; Tony Armstrong of Science Applications International also described this program in full detail. However, the process involved indicates a problem that has been again alluded to in other ways a number of times. The research in this area was started, as I recall, in October 1983. It was finished a year later, let us say, October 1984; the reports are just appearing now, and by the time they are disseminated to the public, the information they contain is going to be too old. A better, more timely system is needed. Now we have to recognize that this was a pilot program. It involved refereed analysis of the materials that were collected, and many other iterations were involved. But still, I don't think we can look upon this process as the final word in any of the four fields that were studied through the commerce project funded by the International Trade Administration.

Cy Braegelmann, of the Foreign Broadcast Information Service (FBIS), talked about his program of translating articles from the Japanese press and journals. Several of you were interested in why you can't see the material, since it is not releasable to the public under international copyright rules. I share this same concern. The information is not classified in any strategic sense, but is restricted only because it doesn't have copyright release. It is extremely valuable and timely information, and $I$, too, wish that it were available to the general public.

Mr. Greenbaum, from the Anmy's Foreign Science and Technology Center, had an unfortunate problem in having been faced with a reorganization a few days before he appeared here. He told us that information collected by FSTC would now be classified and not available to the public. In the older days, meaning two weeks ago maybe, much of the Army's science and technology information generated in Japan could have been available. Some of this information might not have been of great interest to the civilian world since it dealt with quartermaster supplies and similar topics, but there also was a great deal of hightech information there. I have always hated to see truly unclassified information disappear into the "black hole" of the defense intelligence system, never to appear again. The information is gathered, but the question remains whether it is used and used most effectively. I'm afraid that there is only one conclusion that could be reached....

Dr. Butcher described the NSF office in Tokyo as the basis for most of his presentation. This is a very fine office-small but effective. It has now generated in the past two years something like 80 memorandum reports that have no classification markings of any sort on them, available to anybody who takes the effort to go in to the Japan Desk Officer 
in NSF. His name is Dr. Wallace. I use the reports generated by NSF Tokyo continuously. They contain some of the best and most timely information that's available in English on Japanese science policy, budgets, and technical information generally.

I would like to return for just a moment to language training. Lest you think that all government agencies are a bunch of ninnies when it comes to language training, I need to recall for my own protection and for your benefit that the state Department and the Foreign Service do train officers in the Japanese language on a most intensive basis. Let me just mention what is required in learning Japanese as a generalist, and not as a specialist in a scientific field. Japanese is considered one of the two or three most difficult languages of the dozens of languages taught by the Foreign Service Institute. Japanese language training consists of 44 weeks of beginning Japanese and area studies on a full-time basis at the Foreign Service Institute in Arlington, Virginia. This is followed by a year's total inmersion at the Foreign Service Institute's branch in Yokohama, Japan. If he passes the tests, the officer is then released to the Embassy or to one of the consulates, where he then begins to learn real Japanese by being out on his own in the community, speaking colloquial Japanese with the local population. That's the kind of effort that is required to learn Japanese to the point of fluency. I think most Foreign Service officers would agree with the statement made earlier by more than one person here that about 10 years of practice are needed before one begins to feel like he could reach the point of being an interpreter or translator. Even then, people are afraid to do either. The risks of making mistakes are still high.

Mr. Konishi of IBI spoke about the need for going beyond the searching of the literature to find out what was going on in Japan if organizations--private companies in particular-were on the verge of making major business decisions or investments based on their assessment of Japanese progress in science and technology. I think this is a very important consideration. Several speakers referred to the need for hands-on, direct contact with the Japanese, and point out that this is best done through the Japanese language. I would expand on that to some extent by suggesting that more than the language is required. One must understand the cultural enviromment and be able to progress at the pace that the Japanese set for themselves in discussions of this type, and there is a great deal of what Americans feel to be lost time spent in just getting to know each other. Americans are ready to sit down to negotiate at the drop of a hat. Japanese prefer a longer period of making sure that personal relationships are well established and trustworthy before they like to talk about business details. So, there is an acculturation process required in addition to the learning of the langague.

For the first time now, I have seen a good comparison of the performance of the current generation of machine-assisted translation devices, as presented by Mr. Rogers of the Intelligence Community Staff. Mr. Rogers' presentation was a very interesting one. Unfortunately, it seemed to 
show that state-of-the-art of machine-assisted translation is still something short of commercialization. Maybe another six months to a year will sort out the wheat from the chaff.

Professor Ed Daub of the University of Wisconsin gave us his typical illuminating exposition of how to learn technical Japanese through a unique system developed by him and his colleague Professor Bird. This system assumes that the student has had a year of general language training. It then concentrates on the relatively small number of Chinese characters that one must know to read technical Japanese. The system is being modified to enable beginners in the language to start learning technical Japanese immediately.

Mr. Keplinger of the Patent and Trademark Office gave us a general discussion of the field of copyright policy and copyright law. Unfortunately, it is such a lively field that I think we will have to have a whole seminar some day on sorting out the ramifications of protecting proprietary intellectual property in dealing with Japanese technical information.

Dr. Thormpson of the U.S. Department of Education gave a view of learning the Japanese language that conforms to my own biased feelings. Dr. Thompson is an authority and I am not. One should pay attention to what the experts say in this field. I would hope that the Department of Education could somehow muster up its courage and again intervene in the primary and secondary education system of the United States to try to see that Japanese is taught extensively as a foreign language earlier than at the college level. It is much easier to learn by young people in junior or senior high school.

I haven't tried to cover the panel discussion because I think that is still fresh in your memory. The comments made by the distinguished members of the panel constitute an excellent sumary of the issue we have been addressing. 

APPENDIX I

SFMTNAR PROGRAM

Monday, June 24, 1985

SESSION I:

$9: 15-9: 30$

SESSION II:

$9: 35-9: 55$

$10: 00-10: 20$

$10: 20-10: 40$

SESSION III:

$11: 00-11: 30$

$11: 30-12: 00$

$12: 00-12: 30$

SESSION IV:

$1: 50-2: 10$
CHARGE TO SEMINNAR

Rationale and Objectives

Ernest Ambler,

Director, National Bureau of Standards

KEYNOTES

Congressional Concerns

Honorable Doug Walgren,

Chairman, Subcomittee on Science Research and

Technology, U. S. House of Representatives

Interests and Responsibilities of IEFE

Clark Johnson,

Consultant, Minneapolis, Minnesota

The Electronics Industries of the United States and Japan

Pat Hill Hubbard,

Vice President, American Electronics Association, Palo Alto, California

DIMEISSIONS OF THE PROBLEM

What the Practicing Engineer Needs

Robert Gonzalez, Mauro Walker,

Motorola, Inc., Schaumburg, Illinois

What the Industrial Engineer Needs

Jan Vardaman,

MCC, Austin, Texas

What the Education Cormunity Needs

Jacob Schwartz,

New York University, New YOrk, New York

CURRENT PROGRAMS:

A. Of Professional Societies

American Institute of Physics

H. William Koch,

Director, AIP, New York, New York 
$2: 10-2: 30$

$2: 30-2: 50$

$2: 50-3: 10$

$3: 30-3: 50$

$3: 50-4: 10$

$4: 10-4: 30$

$4: 30-4: 50$

$4: 50-5: 10$

SESSION IV:

(cont.)

$9: 30-9: 50$

American Federation of Information Processing Societies

Stephen Yau,

Northwestern Iniversity, Evanston, Illinois

Japan Information Center for Science and

Technology

Yoshio Osada,

Mitsubishi Research Institute, Inc.

Washington, DC

Providing the U.S. with Access to Japanese

Engineering Literature

Herbert Landau,

President, Engineering Information Inc.

New York, New York

B. Of Government Organizations

National Technical Information Service

David Shonyo,

Director, Office of International Affairs, NTIS, Springfield, Virginia

International Trade Aơministration

George Mu,

Office of Japan, ITA, Washington, DC

Foreign Broadcast Information Service

Cyril Braegelmann,

FBIS, Washington, DC

Foreign Science and Technology Center, U.S. Army Phillip Greenbaum,

FSTC, Charlottesville, Virginia

National Science Foundation

William S. Butcher

Director for Engineering, NSF, Washington, DC

Tuesday, June 25, 1985

CURRENT PROGRAMS:

c. Of Commercial Organizations

Japanese Technical Information Service

Herman Baron, Director, UNI-JTIS, Tomoyuki Satoh, Associate Director, Media Pennsylvania 


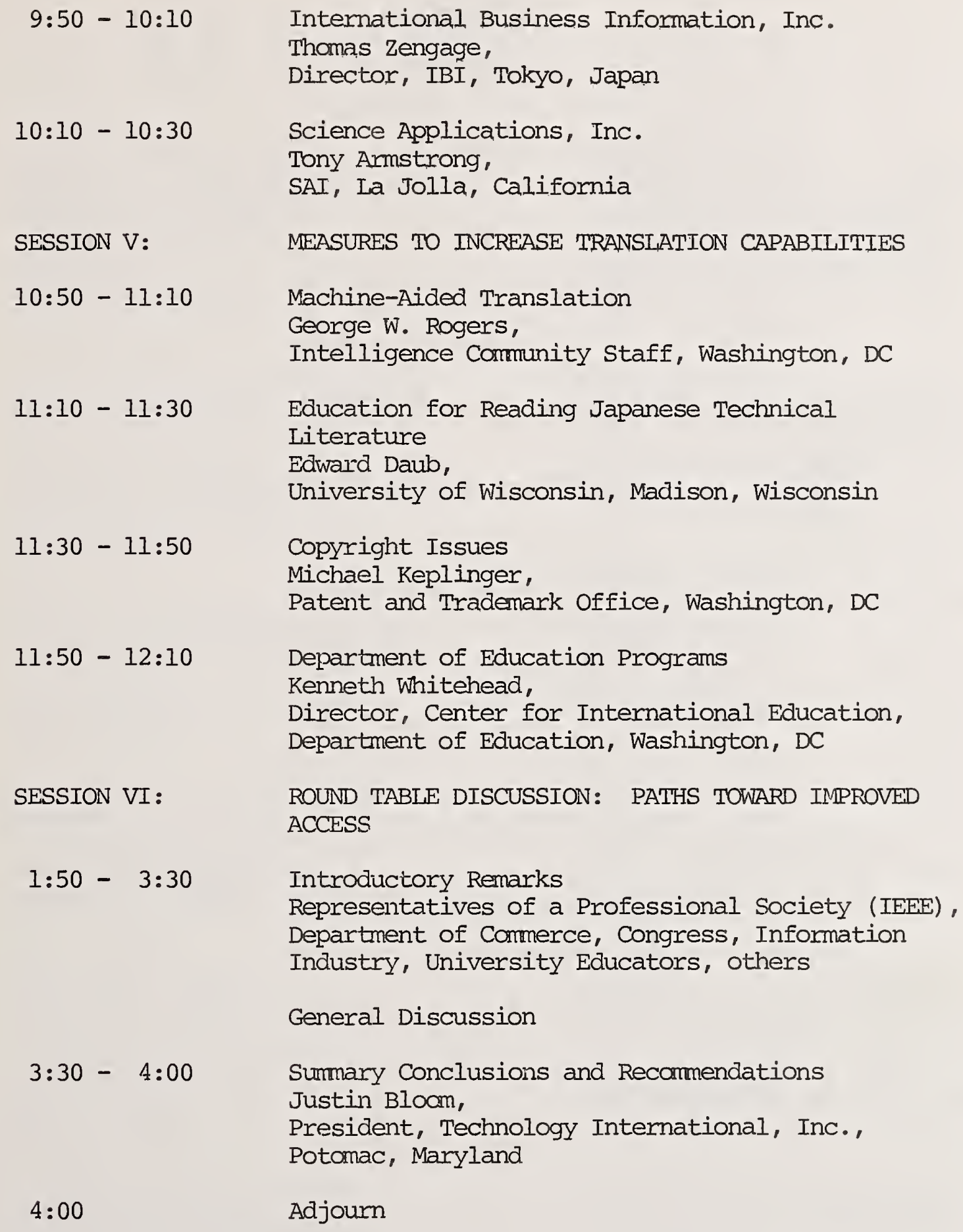


Armstrong, Tony

Director, JTech. Program

Science Applications

International corp.

1200 Prospect

LaJolla, CA 92037

(619) 456-6583

Bach, Maryanne

Republican Technical consultant

House Comittee on Science

and Technology

2319 Rayburn House Office Building

Washington, DC 20515

(202) 225-6371

Baron, Herman

Director, UMI/Japanese Technical Information Service

P.O. Box 976

Media, PA 19063

(215) $565-3190$

Blcom, Justin

President, Technology International, Inc.

11600 Georgetown Court

Potomac, MD 20854

(301) 983-8247

Braegelmann, Cyril

Foreign Broadcast Information Service

P.O. BOX 2604

Washington, DC 20013

(202) 351-2578

Butcher, William

Directorate for Engineering

National Science Foundation

Washington, DC 20550

(202) 357-9834
Coleman, Samuel K.

Associate Director for Research and Program Development

North Carolina Japan Center

North Carolina University

Raleigh, NC 27695

(919) 737-3450

Daub, Edward

Professor, General Engineering

University of Wisconsin-Madison 1527 University Avenue

Madison, WI 53706

(608) 262-0316 x2472

Freitag, Harlow

Chairman, Technical Activities

Board, IEEE

IBM Corporation

White Plains, NY 10604

(914) $696-3450$

Gonzalez, Robert

Motorola, Inc.

Corporate Offices

1303 E. Algonguin Road

Schaumburg, IL 60196

(312) 576-5309

Greenbaum, Phillip

Commander, U.S. Army Foreign

Science and Technology Center

Attn: AIAST-MT-2

220 Seventh Street, NE

Charlottesville, VA 22901-5396

(804) 296-5175 ×433

Hill Hubbard, Pat

Vice President, Educational

Policy \& State Govermment

Operations

American Electronics Association

2670 Hanover Street

P.O. Box 10045

Palo Alto, CA 94303

(415) $857-9300$ 
Ikeda, Kaname

Counselor for Scientific Affairs

Embassy of Japan

2520 Massachusetts Avenue

Washington, DC 20008

(202) 342-9872

Johnson, Clark

Consultant

6400 Barrie Road, Suite 803

Minneapolis, $\mathbb{N} 55434$

(612) 925-0028

Keplinger, Michael

Office of Legislation \&

International Affairs

Patent \& Trademark Office

Box 4

Washington, DC 20231

(202) 557-3065

Koch, William

Director, American Institute of Physics

335 East 45th Street

New York, NY 10017

(516) $349-7800 \times 500$

Konishi, Yasuo

Assistant Washington Representative IBI

2035 Landings Drive

Mountain View, CA 94043

(415) 965-2655

Landau, Herbert

President, Engineering

Information, Inc.

345 East 47th Street

New York, NY 10017

(212) 705-7618

Mu, George

Office of Japan - International

Trade Administration

Room 2318, HCH Building

Department of Commerce

washington, DC 20230

(202) 377-2896
Osada, Yoshio

Chief Representative

Mitsubishi Research Institute,

Inc.

655 15th Street, NW - Suite 880

Washington, DC 20005

(202) 393-2424

Riganati, John

Director of Systems Research

Institute for Defense Analyses

Supercomputing Research Center

4380 Forbes Boulevard

Lanham, MD 20706

(301) 731-8065

Rogers, George

Vice Chairman, Information

Handling Committee

Intelligence Community Staff

Washington, DC 20505

(202) 376-5560

Samuels, Richard

Associate Professor

Massachusetts Institute of

Technology

Cambridge, MA 02139

(617) 253-2449

Satoh, Tomoyruki

Associate Director, UMI/

Japanese Technical Information

Service

P.O. Box 976

Media, PA 19063

(215) $565-3190$

Schwartz, Jacob

Department of Computer Science

Courant Institute of Mathematical

Science

New York University

251 Mercer Street

New York, NY 10012

(212) 460-7267 
Shonyo, David

Director, Office of International Affairs

National Technical Information

Service

U.S. Department of Commerce

5285 Port Royal Road

Springfield, VA 22161

(703) $487-4822$

Thompson, Richard T.

Acting Director, Center for

International Education

U.S. Department of Education

400 Maryland Avenue, SW

Washington, DC 20202

(202) 245-9691

Vardaman, Jan

International Liaison Office

MCC

9430 Research Blvd.

Echelon Building \#1, Suite 200

Austin, TX 78759

(512) 343-0860

Walgren, Doug

Chairman, Subcommittee on Science

Research and Technology

Committee on Science and Technology

House of Representatives

Washington, DC 20515

(202) 225-2135

Walker, Mauro

Motorola, Inc.

Corporate Offices

1303 E. Algonquin Road

Schaumburg, II 60196

(312) 576-5309

Windham, Pat

Professional Staff Member

Subcommittee on Science, Technology and Space

committee on Commerce, Science \&

Transportation

House of Representatives

2321 Rayburn House Office Building

Washington, DC 20515

(202) 224-9361
Yau, Stephen

Department of Electronic

Engineering \& Computer Science Northwestern University

2145 Sheridan Road

Evanston, IL 60201

(312) 491-3641 

1. Paul K. Aoki

Department of Defense

9800 Savage Road

Fort George G. Meade, Md 20755

(301) 688-6149

2. Ronald Aqua

U.S.-Japan Foundation

560 Iexington Avenue

New York, NY 10022

(212) 688-6807

3. Frank Ballance

President, Action for World

Development

2016 15th Street, NW

Washington, DC 20009

(202) 667-0510

4. Yoriko Beach

Department of Defense

(301) 859-6382

5. Don Brown

D. Brown Associates, Inc.

410 Commerce Drive

Fort Washington, PA 19034

(215) 641-9100

6. William T. Brown

Inäustrial Intelligence

Consulting Service

2502 Rocky Branch Road

Vienna, VA 22180

(703) 938-1684

7. Ray Chapman

George Mason University

4400 University Drive

Fairfax, VA 22030

(703) $425-3946$

8. Samuel Coleman

North Carolina Japan Center

Box 8112

North Carolina State University

Raleigh, NC 27695-8112

(919) 737-3185
9. William S. Corak

Advanced Technology Division

Westinghouse Defense and

Electronics Center

P.O. Box 1521 - Mail Stop 3531

Baltimore, MD 21203

(301) 765-7542

10. Diane Devlin

Dept. of Defense

9800 Savage Road

Fort Meade, MD 20755-6000

(301) 688-6953

11. Wendy Ebersberger

Sperry

1901 N. Moore st.

Arlington, VA 22209

(703) 875-0174

12. Harlow Freitag

IBM Corporation (Chairman, Technical Activities Board, IEFE)

Room 2G12

1000 Westchester Avenue

White Plains, NY 10604

(914) 696-5343

13. Susan Goldman

Courant Institute of

Mathematical Sciences

New York University

251 Mercer Street

New York, NY 10012

(212) $460-7270$

14. Hisako K. Halasz

Library of Congress, Science/ Tech Division

Independence \& 2nd Street, S.E. Washington, DC 20540

(202) 287-1210

15. Marie Hall

Dept. of Defense

(301) 859-6382 
16. Frederick Haynes

National Technical Information

Service

5285 Port Royal Road

Springfield, VA 22161

17. Comer M. Heine

National Technical Information Service

5285 Port Royal Road

Springfield, VA 22161

(703) 487-4821

18. Kaname Ikeda

Scientific Counselor

Embassy of Japan

2520 Massachusetts Avenue, N.W. Washington, DC 20008

(202) 234-2266

19. A. Johanson

AT\&T - Bell Laboratories

600 Mountain Avenue

Murray Hill, NJ 07974

(201) $582-6066$

20. Dr. Melvin J. Josephs

National Technical Information Service

5285 Port Royal Road

Springfield, VA 22161

(703) $487-4674$

21. Dr. Stephen Juhasz

Southwest Research Institute

6222 Culebra Road

P. O. Drawer 28510

San Antonio, Texas 78284

(512) 684-5111

22. Keiko Koike

9605 Barkston Court

Potomac, MD 20850

(301) $279-0180$

23. Wayne S. Kiyosaki

Foreign Broadcast Information Service

P. O. Box 2604

Washington, DC 20013

(202) $351-2780$
24. Scott Kostenbauder

IBM Technical Information Retrieval Center

44 S. Broadway

White Plains, NY 10601

(914) $686-3340$

25. Gene Krug

National Science Foundation

1800 G Street, N.W., Room 1229

Washington, DC 20550

(202) 357-7829

26. Bill Kurtz

Nissho Iwai American Corp.

1211 Avenue of the Americas

New York, NY 10036

(212) $704-6526$

27. Choung M. Lee

Dept. of Defense

696-4306

28. Marie D. Low

University Microfilms

International

300 N. Zeeb Road

Ann Arbor, Michigan 48106

(313) $761-4700$

29. Mark Mandelbaum

Association for computing

Machinery

11 West 42nd Street

New York, NY 10036

(212) $869-7440$

30. George L. Marling

Intelligence Community Staff

1724 F Street, NW

Washington, DC 20505

31. Al Marmor

Bethesda, MD

(301) 365-2075

32. Barbara S. McCoy

Consultant

481 Highway 79

Morganville, NJ 08816

(201) 591-0100 
33. Bill McPherson

OES/SCT

Dept. of State

Wasinington, DC 20520

(202) 632-0499

34. Ronald A. Morse

Woodrow Wilson International

Center for Scholars

1000 Jefferson Drive, SW

Washington, DC 20560

(202) $357-1937$

35. Thomas Parry

Wright Patterson Air Force Base

Dayton, Ohio 45433-6508

(513) 257-2247

36. Barbara Payne

National Technical Information

Service

5285 Port Royal Road

Springfield, VA 22015

(703) $487-4612$

37. Paula Randall

DoC Intelligence Liaison Office

38. Frederic N. Ris

IBM Corporation

P. O. BOX 218

Yorktown Heights, NY 10598

(914) 945-1973

39. Bruce Rosenthal

Mita Copystar America, Inc.

777 Terrace Avenue, P. O. Box 813

Hasbrouck Heights, NJ 07604

(201) $288-6900$

40. Thomas Ruddy

International Business

Information, Inc.

2035 Landings Drive

Mountain View, CA 94043

(415) $965-2655$
41. William R. Ryerson

National Technical Information Service

5285 Port Royal Road

Springfield, VA 22161

(703) $487-4778$

42. Richard Samuels

Assoc. Professor

Massachusetts Institute of Technology

Cambridge, MA 02139

(617) $253-2449$

43. Dean Smith

National Technical Information Service

5285 Port Royal Road

Springfield, VA 22161

(703) $487-4802$

44. Philip Stanley

Dept. of Defense

9800 Savage Road

Ft. Meade, MD 20755-6000

(301) 688-9653

45. Philip Thibideau

International Scientific and Technical Activities

NASA Headquarters, NIT-4

Washington, DC 20546

(202) 453-2938

46. Paul Tucci

University Microfilms

International

300 N. Zeeb Road

Ann Arbor, Michigan 48106

(313) $761-4700$

47. Robert Turner

Applied Physics Laboratory

Johns Hopkins University

Johns Hopkins Road

Laurel, MD 20707

(301) 953-6211 
48. Akira Utsumi

Mita Copystar America, Inc.

777 Terrace Avenue, P.O. Box 813 Hasbrouck Heights, NJ 07604

(201) $288-6900$

49. Cecil Uyehara

President, Uyehara International Associates

7614 Arnet Lane

Bethesda, MD 20817

(301) 229-3184

50. Robert S. Walleigh

IEEE

1111 19th Street, NW

Washington, DC 20036

(202) 785-0017

51. Richard Wood

UTII/JTIS

Ann Arbor, Michigan 48106

(313) $761-4700$

52. Kiichiro Yamagishi

Japan Trade Center (JETRO)

1221 Avenue of the Americas

New York, NY 10020

(212) 997-0424

Attendees from National Bureau of

Standards, Gaithersburg, MD 20899

53. Ernest Ambler

Director

(301) 921-2411

54. Edward L. Brady

Associate Director for

International Affairs

(301) 921-3641

55. Esther C. Cassidy

Director, Congressional and

Legislative Affairs

(301) 921-2441
56. Ken Dymond

Computer Scientist

Institute for Computer Sciences and Technology

(301) 921-3274

57. Jean Freedman

Institute for computer Sciences and Technology

(301) 921-3165

58. Judson C. French

Director, Center for Electronics and Electrical Engineering (301) 921-3357

59. George Harmon

Semi Circuits and Devices Division

(301) 921-3621

60. Kurt F. J. Heinrich

Chief, Office of International Relations

(301) 921-2463

61. Lu Jingchun

Assoc. Professor

(301) $921-3520$

62. Thomas N. Pyke

Director, Center for Programming Science and Technology

Institute for Computer Sciences and Technology

(301) 921-3436

63. John P. Riganati

Chief, Systems Components Division

Institute for Computer Sciences and Technology

(301) 921-2705

(Resigned from NBS 7/3/85)

64. Craig VanDegrift

Solid State Physicist

Temperature and Pressure Division

(301) 921-2753 


\section{Congressional Staff}

65. Lauren Ackerman

Office of Technology Assessment 600 Pennsylvania Ave., SE

Washington, DC 20003

66. Georgiana Anderson-Iand

Director, Congressional Caucus for Science and Technology H2-226 House Annex II

Washington, DC 20515

67. Maryanne Bach

Minority Technical Consultant

Subcomittee on Science, Research and Technology

Committee on Science and Technology

2319 Rayburn House Office Bldg. Washington, DC 20515

68. Mary Eccles

Office of Senator John D. Rockefeller, IV

241 Dirksen Senate Office Bldg. Washington, DC 20510

69. Paul T. Feinstein

Comsci Fellow

Office of Congressman Judd Gregg 308 Canon House Office Building Washington, DC 20515

70. Martha Harris

c/o ISC Program

Office of Technology Assessment

Washington, DC 20510

71. Nancy J. Jeffery

Committee on Science and Technology

Subcomittee on Energy Research and Production

Room B-374, Rayburn HOB

Washington, DC 20515
72. Nancy Miller

Library of Congress

Congressional Research Service Room IM-413

Washington, DC 20540

(202) 287-7072

73. Carol Pampliano

Subcommittee on Science, Research and Technology

committee on Science and rechnology

2319 Rayburn House Office Bldg. Washington, DC 20515

74. Todd Stickney

Office of Senator Max Baucus

SH-706 Hart Senate Office Bldg. Washington, DC 20510

75. Jim Turner

Science Consultant

Subcommittee on Science, Research and Technology

committee on Science and

Technology

2321 Rayburn House Office Bldg.

Washington, DC 20515

76. Pat Windham

Professional Staff Member

Subcomittee on Science,

Technology and Space

Cormittee on Cormerce, Science and Transportation

SD-566 Dirksen Senate Office Bldg.

Washington, DC 20510

77. Jcan Winston

Library of Congress

Congressional Research Service

Washington, DC 20540

(202) 287-1437

Press

78. H. Alexander

Byte Magazine

4520 King Street

Alexandria, VA 22302

(703) 820-8304 
79. Joan Amatniek

The Chronicle of Higher Education 1255 23rd Street

Washington, DC 20037

(202) 466-1075

80. Henry Heffernan

GCN

19 Eye St., NW

Washington, DC 20001

(202) 789-1880

81. Janice Johnson

Science Trends

1071 National Press Building

Washington, DC

(202) 393-0031

82. George Leopold

Electronics Week

NY Bureau Editor

McGraw-Hill Info. Systems Co.

1221 Avenue of the Americas

New York, NY 10020

(212) 512-2975

83. Kazuo Nakazato

Kyodo News International, Inc.

50 Rockefeller Plaza, Suite 832

New York, NY 10020

(212) 588-0152

84. Charles Pluckhahn

Investors Daily

809 National Press Building

Washington, DC 20045

(202) 662-7475

85. Stephen J. Shaw

Washington Editor

Mini-Micro Systems

1701 18th St., NW

Washington, DC 20009

(202) 387-8666

86. Doug Wills

Engineering Times

1420 King street

Alexandria, VA 22314

(703) 684-2800 


\section{APPENDIX IV: AN OPEN LETTER TO ATTENDEES}

An open letter to the attendees of the conference on access to technical Japanese literature from the members of the NBS Tuesday noon technical Japanese study group:

Dr. Craig T. Van Degrift, Low Temperature Physicist, Temperature and Pressure Division.

Dr. Ugo Bertocci, Electrochemist, Metallurgy Division.

Dr. Jon T. Hougen, Theoretical Spectroscopist, Nolecular Spectroscopy Division.

Dr. Warren T. Iverson, Microbiologist, Inorganic Chemistry Division.

We wish to present an opinion that scientific and engineering specialists with relatively modest Japanese language training can gain useful access to the Japanese technical literature in their specialities. This contradicts the view repeatedly expressed or implied during the conference that such access must be gained via translations by Japanese language specialists with modest technical training. our opinion is in keeping with the experimental observation that scientists of nonindoeuropean mother tongues have been able, after modest language training, to gain useful access to world technical literatures in their specialities written in English, French, German, Russian, etc.

our Japanese study group has been slowly working through Professor Daub's book on Understanding Technical Japanese, by meeting only one hour a week at noon. We have finished the first 19 of its 25 chapters during the last two years, reading, translating, and mutually criticizing each other, often in the presence of a Japanese guest scientist working at INBS. We concentrate on being able to correctly understand the text, and although we read the text aloud, we do not practice conversation in class. As scientists, we attack the translation questions with an analytic approach, which parallels closely our analytic style of reading technical material in our own language, but which is unlikely to be found in traditional Japanese classes.

We are not recommending that science students or working scientists be required to learn Japanese, since the learning of any language must be motivated by a genuine interest and desire. Instead, we suggest that a suitable atmosphere be provided for the nurturing of existing linguistic curiosity. We feel that probably a substantial number of scientists or engineers has such a latent interest, waiting to be ignited by exposure to the right book, college course, friend, or administrative enviroment.

Even though few in number, such students of scientific Japanese can be very effective in aiding their colleagues to gain access to the Japanese technical literature. Such leverage arises because, to a specialist, 
each scientific article contains only a few crucial nuggets of new information, imbedded in a mass of support and background material. By studying the English abstract (which is often supplied by the Journal), noting equations, figures, references, and various English words included in the Japanese text, a scientist with no Japanese language experience whatever can make a good guess about the existence and location of these nuggets, and can then ask his "bilingual" colleague to translate only that small portion of the text.

In spite of our concentration on reading technical literature, this study has also led to an increase in personal contacts. Our Japanese colleagues seem to appreciate any effort made at understanding their language, and such efforts clearly lead to an increase in informal exchange of technical information beyond that in the published literature.

In summary, we hope that we have made clear the benefits certain to arise by encouraging American scientists to study the Japanese language to an extent commensurate with their interest and available time. In particular, study aids such as Professor Daub's book have proven invaluable to us, for whom the idea of three or four years of "proper" study of the language and literature of Japan is simply impractical. 


$$
\begin{gathered}
\text { 日本の } \\
\text { 科学と技術 }
\end{gathered}
$$

U.S. Access to Japanese Technical Literature:

Electronics and Electrical Engineering

\author{
VISUALS \\ (VOLUME II)
}





\section{CONTENTS}

\section{CHARGE TO SEMINAR}

II. KEYNOTES

Interests and Responsibilities of IEEE

Speaker: Mr. Clark Johnson, Consultant

The Electronics Industries of Japan and the United States

B

Speaker: Mrs. Pat Hill Hubbard, American Electronics Association

\section{DIMENSIONS OF THE PROBLEM}

What the Practicing Engineer Needs

Speaker: Mr. R. Gonzalez, Motorola, Inc.

What the Education Community Needs

D

Speaker: Dr. Jacob Schwartz, New York University

\section{CURRENT PROGRAMS}

\section{A. Professional Societies}

American Institute of Physics

Speaker: Dr. H. William Koch, AIP

American Federation of Information Processing Societies

F

Speaker: Dr. Stephen Yau, Northwestern University

Japan Information Center for Science and Technology

G

Speaker: Mr. Yoshio Osada, Mitsubishi Research Institute

\section{B. Government Organizations}

National Technical Information Service

$\mathrm{H}$

Speaker: Mr. David Shonyo, NTIS

\section{Commercial Organizations}

Japanese Technical Information Service

Speakers: Mr. Herman Baron and Mr. Tomoyuki Satoh, UMI-JTIS

Science Applications, Inc.

Speaker: Dr. Tony Armstrong, SAI

V. MEASURES TO INCREASE TRANSLATION CAPABILITIES

Machine-aided Translation

Speaker: Mr. G.W. Rogers, Jr., Intelligence Community Staff

Education for Reading Japanese TechnicaL Literature Speaker: Dr. Edward Daub, University of Wisconsin 



\section{PREFACE}

U.S. policymakers and private industry at large have recently developed a common interest in the problem of access to Japanese technical literature. Accordingly, the National Bureau of Standards (NBS) and the Institute of Electrical and Electronics Engineers (IEEE) should be commended for jointly organizing and conducting a symposium on this subject in June 1985. Attending this symposium were appropriate representatives from U.S. and Japanese industries, as well as publishers and government officials from both countries.

Following this two-day event, especially in view of our substantial interest in Japanese technological developments, Southwest Research Institute agreed to undertake the task of compiling a printed collection of the viewgraphs and slides used by the speakers at this meeting.

The novel idea for compiling these visuals was advanced by Mr. Justin Bloom during his summarizing remarks at the close of the symposium and subsequently implemented by Dr. Edward L. Brady. Herein presented, this document, entitled VISUALS (Volume II), serves as a companion manual to that compiled by NBS, which contains the keynote speeches and summary.

We gratefully acknowledge the splendid cooperation of the speakers in responding to the request for a copy of their visuals. Additionally, credit is due to Dr. Stephen Juhasz, Editor Emeritus of Applied Mechanics Reviews, now a consultant to SwRI, for his efforts in compiling this material into document form. 
日

本

n

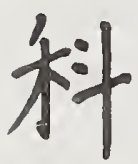

学

乙

技

術
U.S. Access

to Japanese

Technical

Literature:

Electronics

and Electrical

Engineering

Visuals

Volume II 


\section{U.S. Access to Japanese \\ Technical Literature: \\ Electronics and \\ Electrical Engineering}

\section{Visuals}

Name of Session

II. KEYNOTES

Name, Affiliation, and Address of Presenter

Mr. Clark Johnson

Consultant

6400 Barrie Road, Suite 803

Minneapolis, MN 55435

Title of Presentation

Interests and Responsibilities of IEEE

Number of Visuals 4 


\section{IEEE-WHO AND WHAT?}

- Objectives

- Scientific

- Professional

- Societal

- Membership

-Currently Over $1 / 4$ Million

- 200\% Growth in Past 20 Years

-80 Foreign Sections

\section{IEEE ACTIVITIES}

- Conferences-260 Major Meetings Attended by 400,000 People

- Publications -122,000 Pages in Transactions, Journals, and Magazines

- Education-15,700 Participants Accumulated 177,500 Hours in Study Courses and Seminars

- Standards -500 Cumulative

- 20,000 Volunteer Standards Developers 


\section{MAGNETICS SOCIETY}

- One of 33 IEEE Societies

- Membership 2500-Largely Foreign

- Until 1980, Original Japanese Magnetics Published in U.S. Magnetics Society Transactions

- $\quad$ Since 1980, Gradual Increase to Japanese Publications

- Asymmetric Situation-Most Japanese Researchers Read/Write English; Few Americans Read/Write Japanese.

\section{MAGNETICS PUBLICATIONS}

- Decision to Translate and Publish Japanese Magnetics Journals in English

- Copyright Agreement After One Year Negotiations

- Translations by Technical Translators with English Native Language and Fluent in Japanese

- Plan-3000 Pages Translated Yearly for Appearance in Monthly Issues

- Annual Budget $-\$ 250,000$ 



\section{U.S. Access to Japanese \\ Technical Literature: \\ Electronics and \\ Electrical Engineering}

\section{Visuals}

Name of Session

II. KEYNOTES

Name, Affiliation, and Address of Presenter

Mrs.Pat Hill Hubbard

Vice President, Educational Policy and State Government Operations

American Electronics Association

2670 Hanover Street

P.O. Box 10045

Palo Alto, CA 94303

Title of Presentation

The Electronics Industries of the United States and Japan

Number of Visuals $\quad 9$ 


\section{U. S. ELECTRONICS INDUSTRY}

- WORLDWIDE SALES OF \$305 BILLION

- U. S. SALES OF \$225 BILLION

- EMPLOY 2.6 MILLION AMERICANS

- 15\% ANNUAL GROWTH

$\$ 500$ BILLION BY 1990

- FROM 6TH TO 2ND BY YEAR 2000

- EVERY 1 HIGH TECH JOB CREATES 8 SERVICE OR SUPPLIER JOBS 
B-2

\title{
U.S. TRADE WORLDWIDE
}

\author{
1975 \\ 1983 \\ 1984 \\ +\$9 Billion \\ - \$69 Billion \\ - \$123 Billion
}

\section{U.S. ELECTRONICS TRADE WORLDWIDE}

\author{
1980 \\ 1984 \\ + \$6.3 Billion \\ - \$6.8 Billion
}




\section{U.S. - JAPAN ELECTRONICS TRADE}

1980

- \$3.9 Billion - \$15.5 Billion

1984

$$
\text { U.S. - JAPAN TRADE }
$$

June

1984

- \$31 Billion
1985

- \$40 Billion
Dec.

1985 (predicted)

- \$50 Billion 


\section{JAPAN'S TRADE ADVANTAGES}

- 99\% Literate Workforce

- Strong Work Ethic \& Company

Loyalty Productivity

- $50 \%$ U.S. Labor Costs

- Cost of Capital 2 to 3 Times

Less than U.S.

- Ready Availability of Capital

- Government Policies Reinforce

Economic Goals

- Strong Commitment to Engineering Education

- Access to U.S. Technology 


\section{TYPES OF OPERATIONS IN JAPAN}

- 76\% Sales and Service

- 35\% Engineering

- 26\% Manufacturing

- 15\% Regional Headquarters

- $8 \%$ R\&D or Procurement 


\section{U.S. CITIZENS AT JAPAN SITES}

- 6,517 Workers at 34 Companies

- 1 to 2 U.S. Citizens Average Per Company

- 97 Workers Average Per Company 


\section{PROBLEMS IN DEUVERY LANGUAGE TRAINING}

(1) Finding Competent Instructors

(2) Expense

(3) Time Consuming/lmpact on Work Schedules

(4) Convincing Domestic Mgrs. Worth Time/Cost

(5) Inconveniently Scheduled Local Classes 


\section{NEED FOR JAPANESE LANGUAGE}

- 40\% Never a Need

- 47\% Sometimes or Infrequently a Need

- $13 \%$ Often a Need

-1 Will Need in Future 


\section{PERCENT WHO SEE A NEED \\ - $89 \%$ Speaking is Necessary \\ - $63 \%$ Reading is Necessaiy \\ - 58\% Translation is Necessary}




\section{U.S. Access to Japanese \\ Technical Literature: \\ Electronics and \\ Electrical Engineering}

\section{Visuals}

Name of Session

III. DIMENSIONS OF THE PROBLEM

Name, Affiliation, and Address of Presenter

Mr. Robert Gonzalez

Business Associate

Motorola, Inc., Corporate Offices

1303 E. Algonquin Road

Schaumburg, IL 60196

Title of Presentation

What The Practicing Engineer Needs

Number of Visuals 3 


\section{MOTOROLA CURRENT ORGANIZATION}

- Relative Decentralization

- Sectors and Groups

- Responsibilities of Information Groups:

-Identifying

-Acquiring

-Processing

- 3000 Terminals Throughout the Company 
- Enlarging Information Services Center

- Monitoring Global Competition

- Acquiring Relevant Information

- Analyzing Relevant Information

- Dissemination of Results Throughout Corporation 
MOTOROLA \& JAPANESE SCI-TECH LITERATURE

- Beginning of Appreciation of Dimension of Problem

- Eagerness for Establishing On-line Access

- Timeliness

- Comprehensiveness for Motorola Needs

- Abstracts in English

- Text in English

- Journals, Proceedings, Patents, and Technical Bulletins

- Other Sources 


\title{
U.S. Access to Japanese Technical Literature: Electronics and Electrical Engineering
}

\author{
Visuals
}

Name of Session

III. DIMENSIONS OF THE PROBLEM

Name, Affiliation, and Address of Presenter

Dr. Jacob Schwartz

Department of Computer Science

Courant Institute of Mathematical Science

New York University

251 Mercer Street

New York, NY 10012

Title of Presentation

What The Education Community Needs

Number of Visuals 9 


\section{U.S. PREWAR MATHEMATICS}

- High Dependency on European Sources

Germany (Gottingen)

France

- Graduate Studies Abroad

- Mastery of Foreign Language at Graduate Level

- Russian Math Journals Published in English

- USSR Switches in 1950 Totally to Russian in Math Journals

\section{U.S. VS FOREIGN COMPUTER SCIENCE SINCE 1950}

- Computer Literature in '50s Almost Extensively in English

- Foreign Language Requirements Dropped

- Foreign Literature (Not in English) Ignored

- Extensive Competency in English in China Japan USSR 


\section{COMPUTER-RELATED USSR JOURNALS TRANSLATED COVER-TO-COVER}

- Automatic Control and Computer Sciences (Allerton)

- Automatic Documentation and Mathematical Linguistics (Allerton)

- Automatic Monitoring and Measuring (Sci. Inf. Consultants)

- Automation and Remote Control (Plenum)

- Cybernetics (Plenum)

- Differential Equations (Plenum)

- Engineering Cybernetics (Scripta)

- Problems of Information Transmission (Plenum)

- Programming and Computer Software (Plenum)

- Soviet Automatic Control (Scripta)

- Computational Mathematics and Mathematical Physics (Pergamon)

- All Major Mathematics Journals, Numerous Books and Monographs 


\section{IMPORTANT SOURCES ON JAPANESE COMPUTER SCIENCE}

A. ITEMS SELECTIVELY AVAILABLE IN ENGLISH

- JIPDEC Report

- Journal of Information Processing

Selecta from

- JOHO SHORI

- JOHO SHORI GAKKAI RONBUSHI

- Japan Annual Reviews in Electronics, Computers, and Telecommunications

- ICOT Reports

B. OTHER MATERIAL IN JAPANESE

- Trans of the Institute of Electronics and Communications Engineers (IECE)

- JECC Computer Note

- GEKKAN Computer Digest (Current Awareness Clippings)

- JOHO SANGYO SHIMBUN (Industrial Inf. Processing News)

- NIHON JOHO SHIMBUN

- Conf. Proceedings, etc. 
QULITATIVE COMPARISON OF NATIONAL STRENGTHS

\begin{tabular}{|l|c|c|c|}
\hline \multicolumn{1}{|c|}{ AREA } & U.S. & JAPAN & USSR \\
\hline \hline Components & High & High & Weak/Medium \\
\hline $\begin{array}{c}\text { Architectures (Including } \\
\text { Supercomputers) }\end{array}$ & Leading & $\begin{array}{c}\text { Following } \\
\text { Closely }\end{array}$ & Medium \\
\hline Peripherals & High & Leading & Weak \\
\hline Software & $\begin{array}{c}\text { High } \\
\text { Very Broad }\end{array}$ & $\begin{array}{c}\text { Improving } \\
\text { Rapidly }\end{array}$ & Weak/Medium \\
\hline Theory \& Algorithms & High & $\begin{array}{c}\text { Weak } \\
\text { (No Graduate } \\
\text { Training) }\end{array}$ & $\begin{array}{c}\text { Weak } \\
\text { Parallelism }\end{array}$ \\
\hline Manufacturing & High & High & Weak \\
\hline Robotic Applications & Medium & High & Weak \\
\hline
\end{tabular}




\section{D-6}

\section{GENERAL CONCLUSIONS VIS-A-VIS JAPAN}

- Very unwise to remain ignorant of Developments

- Need to Anticipate Trends.

- Intellectual Level of New Technologies Always Rises Long Before Products Eventuate.

- Widespread Literacy Is Essential.

- Must Overcome the U.S. "Not Invented Here" Psychology.

FIELDS OF JAPANESE WORK THAT NEED TRACKING

- Software Systems

- Software Development Tools

- Software Cost and Quality Trends

- New Chip Technologies: HEMT, GaAs, 3-D Technologies, etc.

- Special Purpose Chips

- New Peripherals, Peripheral Cost Trends

- Magnetic Discs

- Laser Discs and Other Storage Products

- Advanced Monitors for CAl and Home Systems

- Robotics

- Developments in Theory 


\section{RECOMMENDATIONS OF IDA PANEL}

\section{(Supercomputers, June 1985)}

- Expanded Awareness of Foreign Technological Developments

- Specific Emphasis on Japan

- Sporadic Efforts Insufficient

- One Stopgap Solution: Minimize Restrictions on Available Information; e.g., Foreign Broadcast Information

- Expansion of NTIS Japan-related Efforts, Including Conference Proceedings

- Encourage Japanese Literacy Programs Organization of University Cooperation

\section{PRIME REQUIREMENTS OF ACADEMIC COMMUNITY}

- Substantial Degree of Literacy

All Significant Languages

All Significant Literature

- Comprehensive Current Holdings

- Comprehensive Translations As Supplement 



\section{U.S. Access to Japanese \\ Technical Literature: \\ Electronics and \\ Electrical Engineering}

\section{Visuals}

Name of Session

IV. CURRENT PROGRAMS

A. Professional Societies

Name, Affiliation, and Address of Presenter

Dr. H. William Koch

Director, American Institute of Physics

335 East 45th Street

New York, NY 10017

Title of Presentation

American Institute of Physics

Number of Visuals 7 
"U.S. ACCESS TO JAPANESE PHYSICS LITERATURE"

1. COUPLING OF ENGINEERING AND PHYSICS LITERATURE (RELEVANT QUOTES FROM SCHMITT AND SCIENCE 85)

2. AIP EXPERIENCES WITH JAPANESE PHYSICISTS, PRIMARY JOURNALS, AND SECONDARY SERVICES

3. POSSIBLE AIP PROGRAMS.

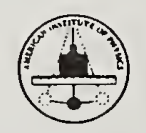

\section{QUOTES FROM ROLAND SCHMITT, NSB CHAIR}

1. "CLOSE LINKAGE BETWEEN GENERATION OF KNOWLEDGE IN UNIVERSITIES AND GENERATION OF NEW TECHNOLOGIES IN INDUSTRY."

2. “ENGINEERING RESEARCH DOESN'T MAKE THE INVENTION ITSELF..."

"IT GENERATES THE KNOWLEDGE THAT CAN BE USED TO MAKE THE INVENTION."

3. PHYSICS "PROVIDES THE FOUNDATION FOR ALL THE REST OF OUR RESEARCH." (IT) "CONCENTRATES MORE ON BASIC RESEARCH AND TEACHING THAN ANY OTHER FIELD."

4. "NARROWING OF THE GAP BETWEEN THE LEADING EDGE OF RESEARCH AND THE CUTTING EDGE OF APPLICATION (IS) SOMETHING PHYSICISTS CAN HELP PROVIDE."

5. "SHORTENING THE TIME LAG" BETWEEN ACQUISITION AND UTILIZATION. 


\section{QUOTE FROM SCIENCE 85 SUPPLEMENT ON NEW NATIONAL GOAL FOR JAPAN}

"CREATIVE RESEARCH - BASIC SCIENCE - IS THE NEW NATIONAL GOAL. HAVING REACHED THE ZENITH OF SCIENTIFIC APPLICATION IN PRODUCTION, THE JAPANESE CONSENSUS SEEMS TO BE IT IS TIME TO MOVE IN A NEW DIRECTION. THE MESSAGE OF THE TSUKUBA SCIENCE EXPO IS CLEAR: THE FUTURE IS CREATIVITY, AND THE FUTURE IS NOW."
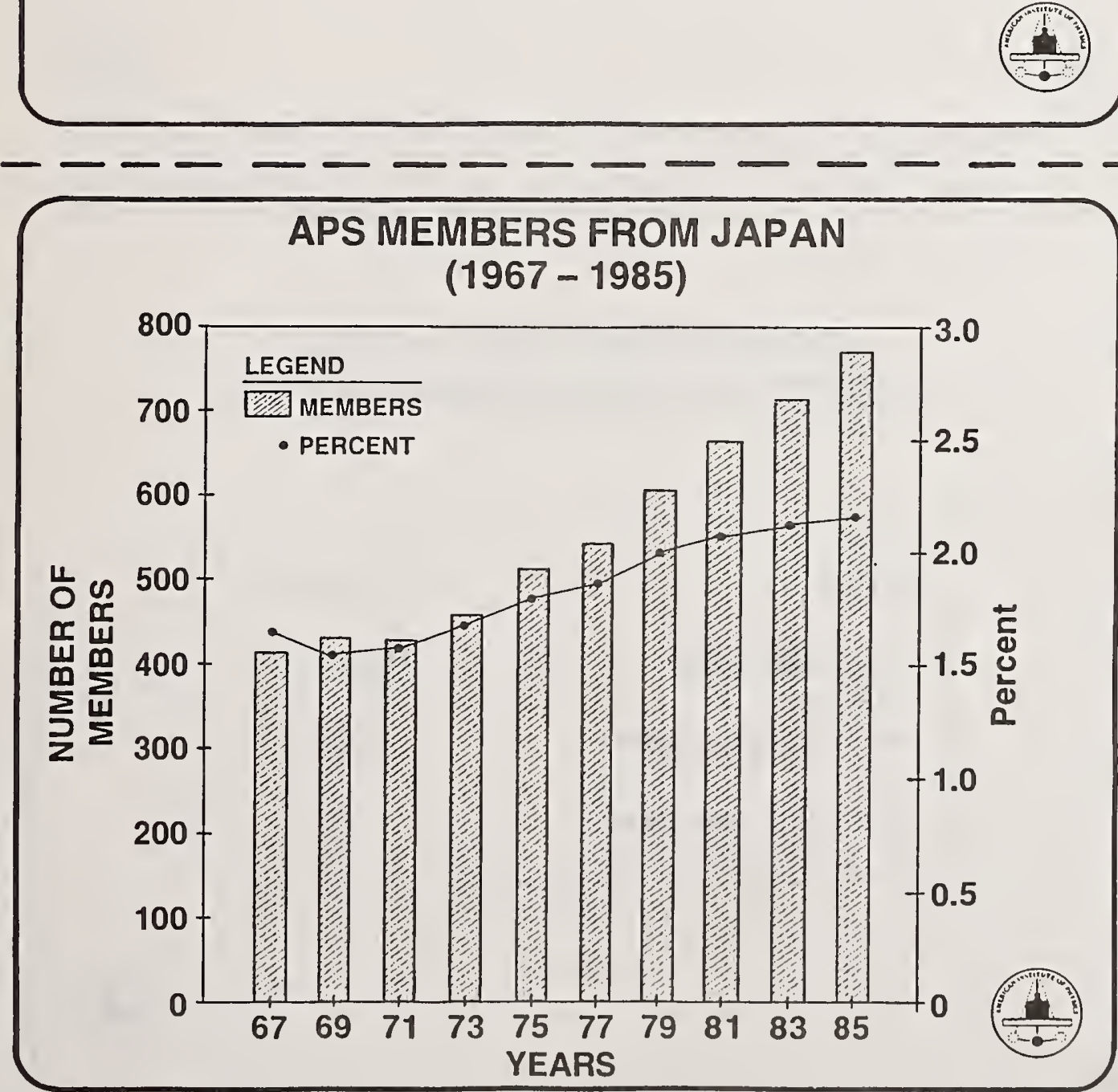

E-4 
PERCENT ARTICLES IN U.S. PRIMARY JOURNALS BY JAPANESE AUTHORS

\begin{tabular}{|lrrrrrr|}
\hline Journals & 1979 & 1980 & 1981 & 1982 & 1983 & 1984 \\
\hline JAP, APL & 11.7 & 12.5 & 12.1 & 12.2 & 13.2 & 14.6 \\
JCP, JMP, others & 5.1 & 5.8 & 6.1 & 5.9 & 5.6 & 5.6 \\
PR, PRL, others & 3.6 & 3.7 & 3.3 & 4.0 & 4.3 & 4.5 \\
\hline
\end{tabular}
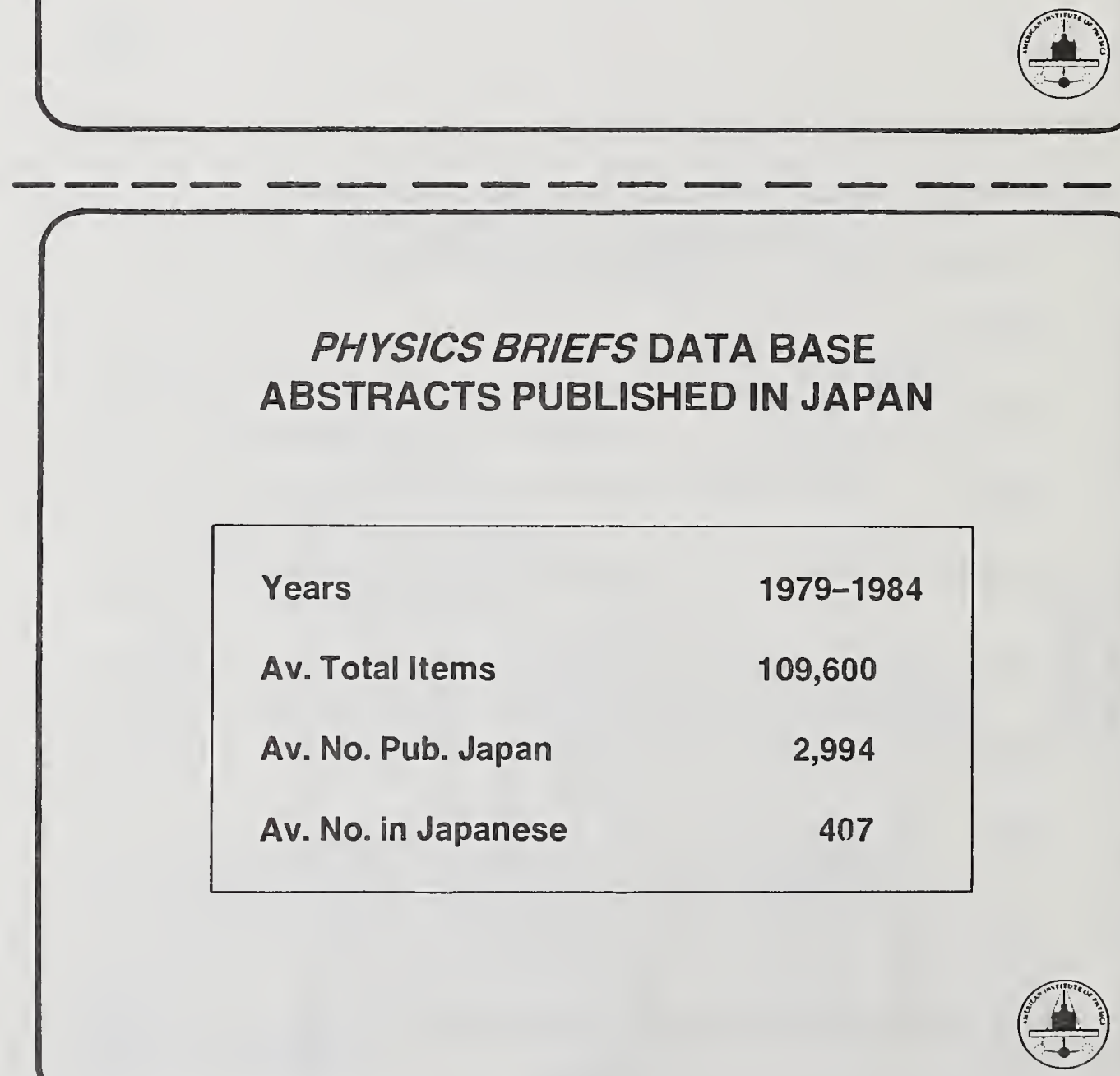


\section{POSSIBLE AIP PROGRAMS}

1. IMPROVE U.S. ACCESSIBILITY TO JAPANESE PRIMARY JOURNALS BY IMPROVED MARKETING AND TRANSLATION PROGRAMS.

2. ENCOURAGE JAPANESE TO MAINTAIN OPEN SCIENTIFIC SOCIETIES.

3. SHORTEN TIME LAG BETWEEN ACQUISITION OF NEW KNOWLEDGE AND ITS UTILIZATION. 



\section{U.S. Access to Japanese}

Technical Literature:

Electronics and

Electrical Engineering

\section{Visuals}

Name of Session

IV. CURRENT PROGRAMS

A. Professional Societies

Name, Affiliation, and Address of Presenter

Dr. Stephen S. Yau

President, American Federation of Information Processing Societies and

Chairman, Department of Electrical Engineering and Computer Science Northwestern University

2145 Sheridan Road

Evanston, IL 60201

Title of Presentation

American Federation of Information Processing Societies

Number of Visuals 2 


\section{AMERICAN FEDERATION OF INFORMATION PROCESSING SOCIETIES}

Constituent Societies

- American Society for Information Science (ASIS)

- American Statistical Association (ASA)

- Association for Computational Linguistics (ACL)

- Association for Computing Machinery (ACM)

- Association for Educational Data Systems (AEDFS)

- Data Processing Management Association (DPMA)

- Institute of Electrical and Electronics Engineers Computer Society (IEEE-CS)

- Instrument Society of America (ISA)

- Society for Computer Simulation (SCS)

- Society for Industrial and Applied Mathematics (SIAM)

- Society for Information Display (SID) 


\section{F-2}

\section{SOME AFIPS JAPANESE-RELATED INFORMATION ACTIVITIES}

- Cosponsor of U.S.-Japan Computer Conferences

- Cosponsor Study Panel on International Development on Microelectronics and Computer Sciences

- Constituent Society IEEE/Computer Society Accesses Some Japanese Technical Literature 



\section{U.S. Access to Japanese \\ Technical Literature: \\ Electronics and \\ Electrical Engineering}

\section{Visuals}

Name of Session

IV. CURRENT PROGRAMS

A. Professional Societies

Name, Affiliation, and Address of Presenter

Mr. Yoshio Osada

Chief Representative

Mitsubishi Research Institute, Inc.

Washington Liaison Office

65515 th Street NW, Suite 880

Washington, DC 20005

Title of Presentation

Current Programs of the Japan Information Center for Science and Technology

Number of Visuals 18 


\section{BRIEF PRESENTATION OF JICST AND JOIS}

\section{FILED NAMES:}

\begin{tabular}{l} 
TITLE: \\
\hline ORIGINAL TITLE:
\end{tabular}

\section{AUTHORS: \\ SOURCE:}

ABSTRACT:
KEYWORDS:

FREE TERMS:

HH

$$
U: k
$$
JICST ON-LINE SERUICE

For Logging in

U: FJOISE 13J-0170, SATO

S: PASSLDRD ?

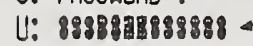

S: SERUICE STARTED 1984.10.16

U: FFILE K5O/ALL

S: JMEOICINEK ( 1981.04 - 1984.11 j 163,284 ( TILL 20:00)

SEARCH STARTEO 17:12:3? SESSION NO.1401

JICST COPYRIGHT

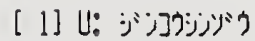

s: 650

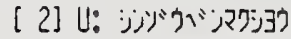

S: 1047

[ 3] U:: $1 * 2$

S: $\quad 25$

[4] U: LN=EN

S: $\quad 3$

[5] U: $\mathrm{PP} \mathrm{A}_{2}$ ]

\#0001 (4826?18)

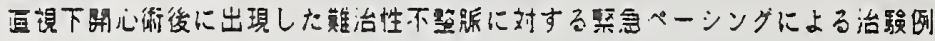

Cardiac a I I hythmlas followlng an open heart surgery of atrial septal defect,

trea $t \in d \quad s u c c e s s f u l$ y wl th temporal

Combring retrieved sets

Enter $¥$ JOIS and Password

Now you are connected to JOIS

Selecting JICST Files

Enter ¥FILE code/coverage

emergency Dacing.

NAKAGAWA A, SAKAMOTO K, MIKAJIMA T, ARAKI

$M$, AKA.GI $M$ ( $K$ umamoto Un।V.)

2764A (0003-9152) 日本外科垔函 VOL. 52, NO. 5 PAGE. 703-709'83

(J) (Al) (EN) (JPN) (写图 3参 6)

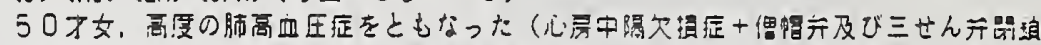

Limiting to a Language

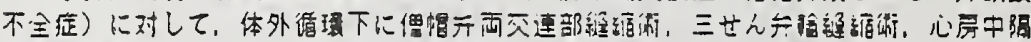

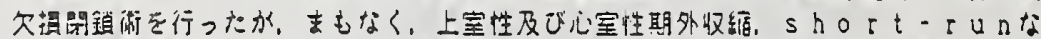

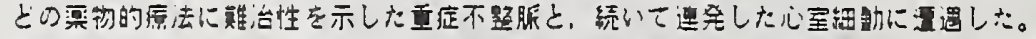

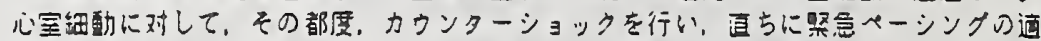

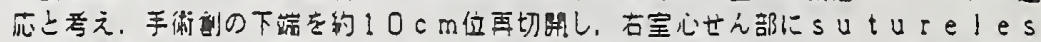

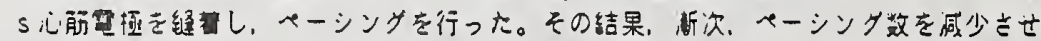

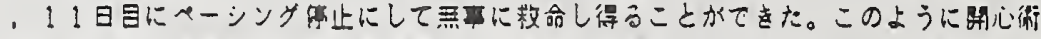

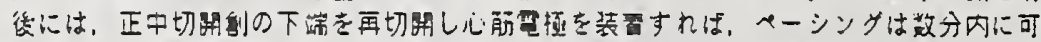

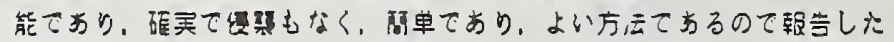
GJ03020Y, GJ05010B $(6 ! 6.12,616.12-08)$

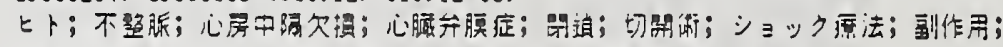

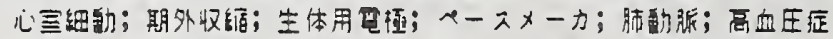

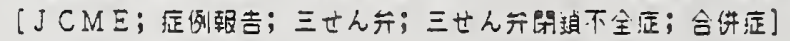

S: OUTPUT FINISHED

[5] U: YEND

*** DATABASE

*** JMEDISINEK

*** TOTAL
FEE TIME FP-FEE YOFF A
$\$ 630$
3

$\$ 630 \quad 3$
JICST COPYRIGHT

YOFF A YOFF F KEEP

MOFF F KEEP
$0(0) \quad 0$

For Printing online

Enter ¥P

A, 1 for the first record with abstract

Offline printing is done by

¥OFF and mailed to a user address 


\section{WHAT IS JICST?}

THE JAPAN INFORMATION CENTER OF SCIENCE AND TECHNOLOGY (JICST) IS THE CENTRAL ORGANIZATION IN JAPAN OF INFORMATION ACTIVITIES FOR THE ADVANCEMENT OF SCIENCE AND TECHNOLOGY. THE CENTER WAS ESTABLISHED AS A SPECIAL NON-PROFIT ORGANIZATION UNDER LEGISLATIVE ACT ON AUGUST 16, 1957. JICST IS UNDER THE EXECUTIVE CONTROL OF THE SCIENCE AND TECHNOLOGY AGENCY.

JICST IS FINANCED BY INCOME FROM TWO SOURCES, NAMELY, GOVERNMENTAL SUPPORT, AND SUBSCRIPTION AND SERVICE FEES, IN PRINCIPLE, THE COST OF COLLECTION AND PROCESSING IS PROVIDED BY THE GOVERNMENT. SERVICE COSTS ARE MET FROM SALES INCOME。 


\section{WHAT DOES JICST DO?}

THE PURPOSE AND ACTIVITIES OF JICST ARE:

1. TO COLLECT SCIENTIFIC AND TECHNOLOGICAL INFORMATION COMPREHENSIVELY ON A WORLD-WIDE SCALE.

2. TO PROCESS THIS INFORMATION SYSTEMATICALLY.

3. TO DISSEMINATE INFORMATION RAPIDLY AND APPROPRIATELY TO ORGANIZATIONS AND INDIVIDUALS, REGULARLY OR UPON REQUEST.

4. TO OFFER ASSISTANCE TO OTHER FAR-REACHING SERVICES TO ENCOURAGE THEIR SCIENTIFIC AND TECHNOLOGICAL INFORMATION WORKS.

TO THESE ENDS, JICST ENGAGES IN THE FOLLOWING SERVICES:

1. PUBLICATION OF ABSTRACTS JOURNALS IN PHYSICAL SCIENCES AND ENGINEERING

2. CUSTOM SEARCH SERVICE

3. LITERATURE SEARCH SERVICE (ON-LINE SERVICE, SDI SERVICE)

4. TRANSLATION SERVICE

5. PHOTODUPLICATION SERVICE. 


\section{COLLECTION OF MATERIALS}

THE WORKING COLLECTION OF JICST NOW AMOUNTS TO ABOUT $1 \emptyset, 86 \emptyset$ JOURNALS, OF WHICH 6,810 ARE FOREIGN. ALSO INCLUDED IN THE COLLECTION ARE TECHNICAL REPORTS (SUCH AS P.B., D.O.E., NASA), CONFERENCE PROCEEINGS AND PATENT SPECIFICATIONS FROM THE UNITED STATES, GREAT BRITAIN AND THE FEDERAL REPUBLIC OF GERMANY.

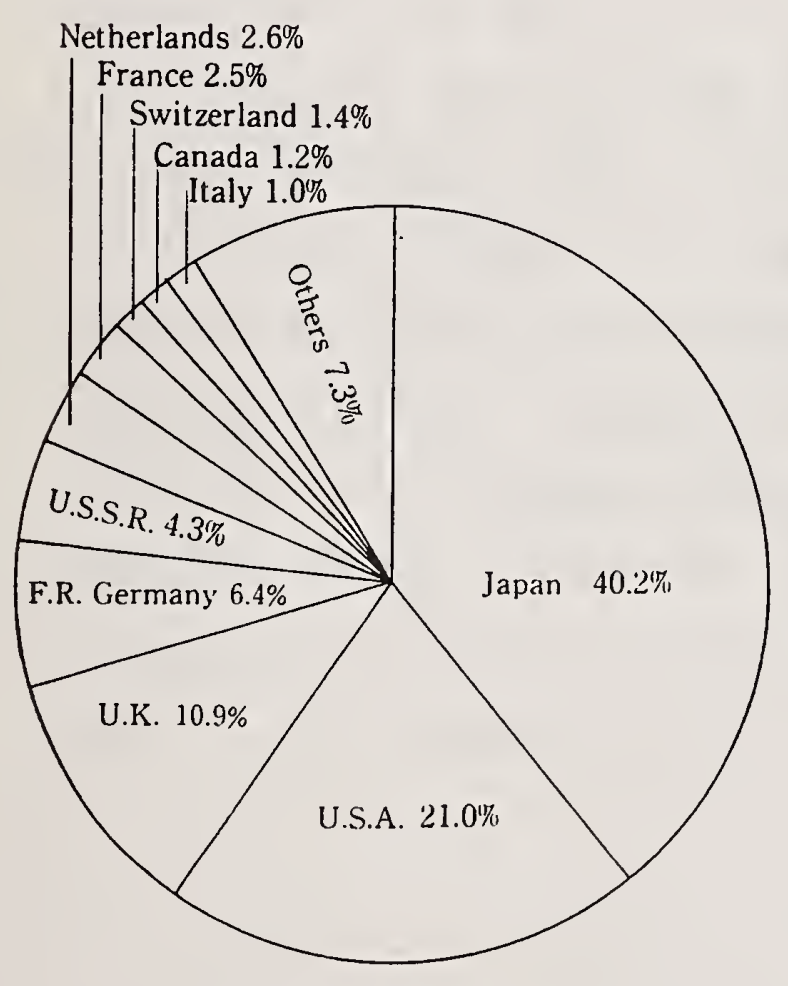

Journal Titles by Country

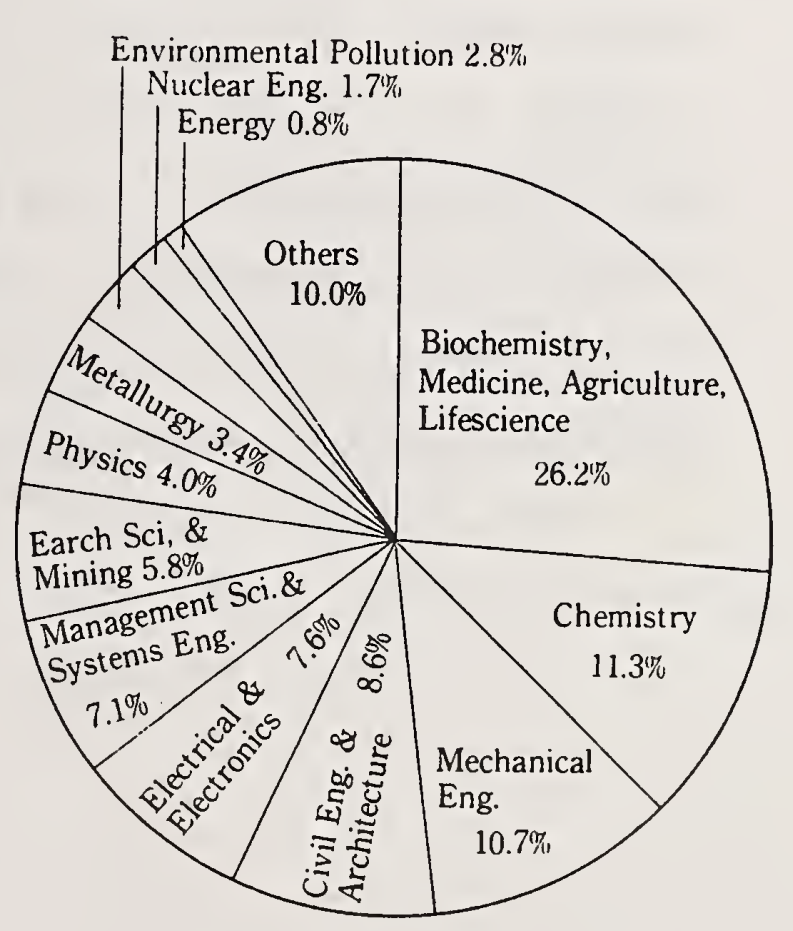

Journal Titles by Subject 
MAJOR ENGL ISH PUBLICATIONS (1)

CURRENT SCIENCE AND TECHNOLOGICAL RESEARCH IN JAPAN( 1985)

THIS BOOK (ENGLISH VERSION AVAILABLE) CONSISTS OF 16,216 CLASSIFIED "RESEARCH THEMES" OF NATIONAL AND PUBLIC EXPERIMENTAL INSTITUTIONS AND INSTITUTES OF UNIVERSITIES. INDEXES ARE DIVIDED INTO SUBJECT INDEX, RESEARCHER INDEX AND RESEARCH ORGANIZATION INDEX AND ARE THUS EASY TO REFER. THOSE NATIONAL AND PUBLIC INSTITUTIONS LISTED IN THIS BOOK ARE ALL LEADING INSTITUTIONS IN JAPAN. THE 1985 EDITION (VOL.3) CONSISTS OF 994 PAGES IN A4 SIZE. 
MANOR ENGLISH PUBLICATIONS (2)

ABSTRACT JOURNALS OF SCIENCE AND TECHNOLOGY IN JAPAN (ENGLISH VERSTON)

\section{(1) ELECTRONICS AND COMMUNICATION (1985)}

THIS ABSTRACT JOURNAL COVERS ALL THE CURRENT INFORMATION OF RESEARCH AND DEVELOPMENT AS WELL AS APPLICATION TECHNOLOGY IN THE FIELD OF ELECTRONICS AND COMMUNICATIONS, IN WHICH JAPAN IS ONE OF THE MOST ADVANCED COUNTRIES. FOUR ISSUES ARE TO BE PUBLISHED ANNUALLY AND FIRST ISSUE WHICH CONTAINS 506 ARTICLES HAS ALREADY BEEN PUBLISHED. THE FIRST ISSUE OF 1985 (VOL. 1, NO.1) CONSISTS OF 83 PAGES IN A4 SIZE. 
MAJOR ENGLISH PUBLICATIONS (3)

ABSTRACT JOURNALS OF SCIENCE AND TECHNOLOGY IN JAPAN (ENGLISH VERSTON)

(2) RENEWABLE ENERGY (1985)

JAPAN HAS REMARKABLY DEVELOPED ADVANCED TECHNOLOGIES FOR EFFECTIVE REUSE OF ENERGY RESOURCES, BECAUSE JAPAN IS POOR IN SUCH RESOURCES. THIS ABSTRACT JOURNAL COVERS ALL THE INFORMATION OF THESE TECHNOLOGIES. THE 1985 EDITION (VOL.5, NO.5) CONSISTS OF 49 PAGES AND CONTAINS 302 ARTICLES. 


\section{JICST ON-LINE INFORMATION SYSTEM(JOIS)}

JICST HAS DEVELOPED "JOIS" (JICST ON-LINE INFORMATION SYSTEM), THROUGH WHICH ON-LINE INFORMATION RETRIEVAL SERVICES OF SCIENTIFIC AND TECHNOLOGICAL DOCUMENTS AND CURRENT RESEARCH THEMES ARE PROVIDED.

JICST STARTED THE EXPERIMENTAL ONLINE INFORMATION RETRIEVAL SERVICE IN APRIL, 1976.

FULL-SCALE OPERATION OF JOIS STARTED FROM JUNE, 1978 BY UTILIZING THE PUBLIC TELECOMMUNICATION LINES.

IN OCTOBER, 1980. THE INTER-CONNECTING NETWORK WAS CONSTRUCTED WITH THE LEASED AND PUBLIC TELECOMMUNICATION LINES IN TEN MAJOR CITIES OF JAPAN, THEREBY ESTABLISHING A REAL PUBLIC TLELCOMMUNICATION LINE NETWORK ELIMINATING REGIONAL DIFFERENCE IN ACCESS AND UTILIZATION CAPABILITY. 
2015-11

A MORE ADVANCED ONLINE SYSTEM, JOIS-11, HAS BEEN IN OPERATION SINCE APRIL. 1981. JOIS-II IS AN INTERNATIONAL COMMERCIAL ONLINE SYSTEM HOLDING 2,600 PASSWORDS AND ACCEPTING 70, SETS OF QUESTIONS PER MONTH AT PRESENT IN JAPAN. IN THE MEANTIME, THE NUMBER OF JOIS SERVICED DATABASES HAS INCRESASED TO 17 IN TOTAL, AND SYSTEM CAPABLITITES HAVE BEEN EXPANDED EVERY YEAR。 


\section{SEARCH CAPABILITY OF JOIS}

THE SYSTEM PERFORMS THE FULLMATCHING AS WELL AS RIGHT AND LEFT HAND TRUNCATION ON THE BASIS OF KEY WORDS WHICH ARE ENTERED BY THE TERMINAL. IT IS ALSO CAPABLE OF LOGICAL SEARCH OF ARTICLES BY USING AND, OR AND NOT FUNCTIONS, AS WELL AS LIMITING THE NUMBER OF SEARCHES BY SUCH MEANS AS LANGUAGE, AUTHOR, PUBLICATION DATE,ETC.

ANOTHER FEATURE OF THE SYSTEM IS THAT IT CAN STORE, IN ADVANCE, ALL SEARCH COMMANDS ON A SPECIFIC SUBJECT, SO THAT THE SYSTEM CAN CONDUCT AN AUTOMATIC SEARCH UPON EVERY MONTHLY UPDATED DATA OF EACH FILE AND DELIVER THE RESULTS TO THE USERS. 


\section{DATABASES AVAILABLE IN JOIS}

(1) JICST FILE ON SCIENCE AND TECHNOLOGY

(2) JICST FILE ON MEDICAL SCIENCE IN JAPAN

(3) JICST FILE ON CURRENT SCIENCE AND TECHNOLOGY RESEARCH IN JAPAN

(4) JICST FILE ON GOVERNMENT REPORTS IN JAPAN

(5) NIKKAN KOGYO FILE ON NEN TECHNOLOGY AND PRODUCTS IN JAPAN

(6) JICST THESAURUS FILE

(7) JICST HOLDING LIST FILE

(8) JICST TRAINING FILE ON SCIENCE AND TECHNOLGY

AT PRESENT, THESE DATABASES ARE WRITTEN IN JAPANESE, BUT ENGLISH VERSION FOR (1) AND (2) IS SCHEDULED TO BECOME AVAILABLE IN APRIL, 1986. 


\section{JICST FILE ON SCIENCE AND TECHNOLOGY}

IT COVERS $9, \emptyset \emptyset \emptyset$ TITLES OF SERIALS, TECHNICAL REPORTS, CONFERENCE PAPERS PUBLISHED IN 50 MAJOR COUNTRIES, WHICH ARE ACQUIRED BY JICST. JICST ANNUALLY PREPARES ABSTRACT AND KEY WORDS OF ABOUT 460,000 (CITATIONS/YEAR) APPEARING IN THE ABOVE LITERATURE AND INCLUDES THEM IN THE DATABASE.

KEY WORDS AND CLASSIFICATION CODES ASSIGNED IN THE FILE ARE BASED ON "JICST THESAURUS ON SCIENTIFIC AND TECHNOLOGICAL TERMS" AND "JICST SCIENCE AND TECHNOLOGY CLASSIFICATION TABLE" RESPECTIVELY.

JICST FILE ON SCIENCE AND TECHNOLOGY IS USED NOT ONLY FOR ON-LINE INFORMATION RETRIEVAL BUT ALSO FOR COMPILATION OF PRINTED VOLUMES, CURRENT BIBLIOGRAPHY ON SCIENCE AND TECHNOLOGY: 12 SERIES. 
JICST FILE ON SCIENCE AND TECHNOLOGY

SUBJECT COVERAGE

SCIENCE \& TECHNOLOGY

CHEMISTRY

BIOLOGICAL SCIENCE

MEDICINE

SYSTEMS/CONTROL ENGINEERING

MANAGEMENT ENGINEERING

NUCLEAR SCIENCE

THERMAL ENGINEERING \&

APPLIED THERMODYNAMICS

CONSTRUCTION ENGINEERING

TRANSPORT \& TRAFFIC ENGINEERING

METAL SCIENCE \& TECHNOLOGY

CHEMICAL TECHNOLOGY
PHYSICS

SPACE/EARTH SCIENCES

AGRICULTURE, FORESTRY \& FISHERIES

ENGINEERING

COMPUTER SCIENCE \& TECHNOLOGY

ENERGY TECHNOLOGY

ELECTRICAL \& ELECTRONIC ENGINEERING

MECHANICAL ENGINEERING

ENVIROMENTAL ENGINEERING

MINING ENGINEERING

CHEMICAL ENGINEERING

MISCELLANEOUS TECHNOLOGY 


\section{JICST FILE ON MEDICAL SCIENCE IN JAPAN}

JICST FILE ON MEDICAL SCIENCE IN JAPAN IS PREPARED IN COOPERATION WITH "IGAKU CHUOU ZASHI KANKOUKAI" AND PROVIDED BY THE JAPAN INFORMATION CENTER OF SCIENCE AND TECHNOLOGY (JICST).

IT COVERS MAJOR DOMESTIC JOURNALS IN THE FIELDS RELATED TO MEDICINE. AS TO MAKING JAPANESE ABSTRACTS AND ASSIGNING KEY WORDS AND CLASSIFICATION CODES TO CITATIONS APPEARING IN THE ABOVE LITERATURE SOURCES, JICST IS RESPONSIBLE FOR BIOSCIENCES AND PHARMACEUTICAL SCIENCE WHILE "IGAKU CHUOU ZASHI KANKOUKAI" IS RESPONSIBLE FOR OTHER FIELDS RELATED TO MEDICINE. IT ADDS ABOUT $60,00 \emptyset$ CITATIONS ANNUALLY.

KEY WORDS AND CLASSIFICATION CODES ASSIGNED IN JICST FILE ON MEDICAL SCIENCE IN JAPAN ARE IN ACCORDANCE WITH "JICST THESAURUS ON SCIENTIFIC AND TECHNOLOGICAL TERMS" AND "JICST SCIENCE AND TECHNOLOGY CLASSIFICATION TABLE", RESPECTIVELY. ABBREVIATION OF AUTHOR AFFILIATIONS AND CORPORATE AUTHORS IS IN ACCORDANCE WITH THE JICST FILE ON SCIENCE AND TECHNOLOGY. JICST FILE ON MEDICAL SCIENCE IN JAPAN IS AVAILABLE ONLY FOR ON-LINE RETRIEVAL. 


\section{JICST FILE ON MEDICAL SCIENCE IN JAPAN}

SUBJECT COVERAGE

BIOLOGICAL SCIENCE

BIOLOGICAL SCIENCE/GENERAL

B IOCHEMISTRY

GENETICS AND EVOLUTION

IMMUNOLOGY

ECOLOGY AND ENVIROMENTAL BIOLOGY

CYTOLOGY

MICROB IOLOGY AND VIROLOGY

ZOOLOGY

RADIOBIOLOGY

BIOENGINEERING

VETERINARY MEDICINE

MEDICINE

MEDICINE/GENERAL

PREVENTIVE AND SOCIAL MEDICINE

CL INICAL MEDICINE/GENERAL

DISEASES (IRRESPECTIVE OF BODY

PART, SYSTEM OR ORGAN)

ONCOLOGY

DERMATOLOGY

CL INICAL MEDICINE/MUSCULOSKELETAL SYSTEM

CLINICAL MEDICINE/DIGESTIVE SYSTEM

CLINICAL MEDICINE/RESPIRATORY SYSTEM

CLINICAL MEDICINE/CARDIOVASCULAR SYSTEM

CLINICAL MEDICINE/BLOOD AND LYMPHATIC SYSTEM

CLINICAL MEDICINE/ENDOCRINE SYSTEM

CLINICAL MEDICINE/UROGENITAL SYSTEM

NEUROLOGY

OPTHALMOLOGY

OTORHINOLARYNGOLOGY

PSYCHIATRY

GYNECOLOGY AND OBSTETRICS

DENTISTRY

PHARAMACEUTICAL SCIENCE/GENERAL

PHARMACODYNAMICS

PHARAMACOLOGY

ANTIBIOTICS AND PHARMACOGNOSTICS

DISPENSING AND MANUFACTURING PHARMACY

TOXICOLOGY 


\section{UTILIZATION OF JOIS IN JAPAN}

THE FOLLOWING SHOWS THE PAST GROWTH OF UTILIZATION OF JOIS IN JAPAN:

$\begin{array}{llll}1977 & 1979 & 1981 & 1984\end{array}$

NO. OF USERS $20 \quad 500 \quad 1100 \quad 2600$ (AS OF SEPT.)

NO. OF HOURS

USED PER MONTH $200 \quad 1200 \quad 24 \varnothing 0 \quad 5900$

THE GROWTH IN RECENT YEARS EXCEEDS $3 \emptyset$ PERCENT PER YEAR. 


\section{FUTURE PROSPECT (1)}

FOR THE FUTURE JICST CONSIDERS IT AS THE MOST IMPORTANT TASK TO BECOME A KEY MEANS OF DISSEMINATING THE LATEST INFORMATION ON JAPAN'S SCIENCE AND TECHNOLOGY TO THE WHOLE WORLD IN ENGLISH. FOR THE TIME BEING JOIS WILL HAVE TO PROVIDE INFORMATION IN THE JAPANESE LANGUAGE, AND THIS REQUIRES THE USE OF AN ENGLISH/KANA TYPE OR A "KANJI" (CHINESE CHARACTER SETS) TERMINAL. HOWEVER, COMMENCING FROM APRIL, 1986, JICST WILL START A SERVICE IN WHICH SEARCHING CAN BE MADE BY ORDINARY ASCII TERMINALS, AS THE TITLES AND KEY WORDS FOR THE JICST FILES OF JAPANESE DOCUMENTS WILL BE TRANSLATED INTO ENGLISH BY THEN. 


\section{FUTURE PROSPECT (2)}

IN ADDITION, JICST IS PLANNING TO ESTABLISH ADEQUATE INFRASTRUCTURES TO ENABLE LARGE-SCALE TRANSLATION AND COPYING SERVICES OF THE JAPANESE DOCUMENTS IN RESPONSE TO THE REQUESTS FROM OVERSEAS. ALSO, ALONG WITH THE DOCUMENT SEARCH, THE JOIS SERVICE WILL BE EXPANDED TO INCLUDE A FACTUAL DATA BASE ON CHEMICAL COMPOUNDS. 


\section{U.S. Access to Japanese \\ Technical Literature: \\ Electronics and \\ Electrical Engineering}

\section{Visuals}

Name of Session

IV. CURRENT PROGRAMS

B. Government Organizations

Name, Affiliation, and Address of Presenter

Mr. David Shonyo

Director, Office of International Affairs National Technical Information Service 5282 Port Royal Road

Springfield, Virginia 22161

Title of Presentation

National Technical Information Service

Number of Visuals

16 


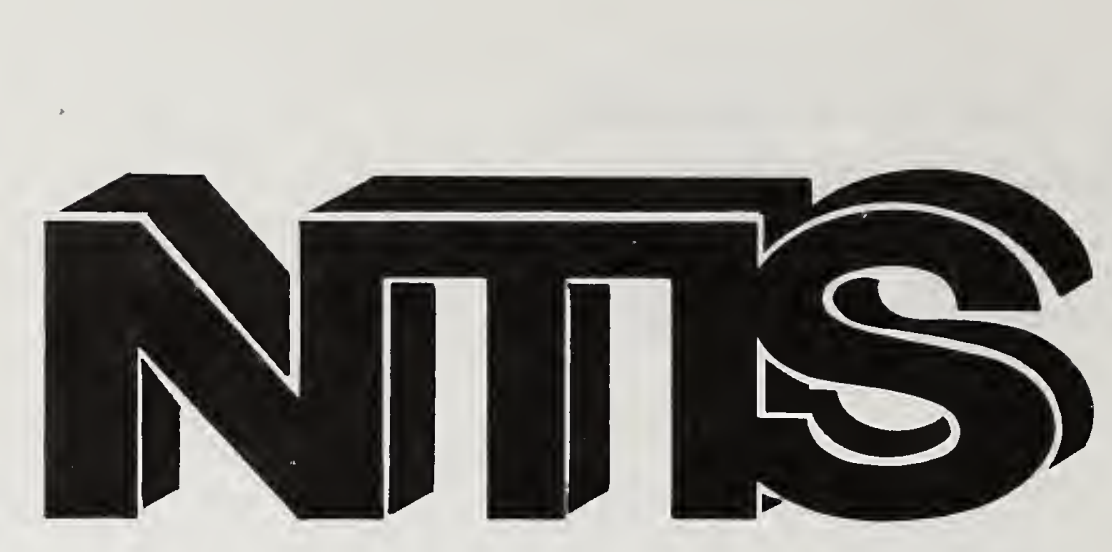

\section{$\mathrm{H}-1$}

\section{HISTORY OF NTIS}

1945 Publication Board

1946 Office of Technical Services

1964 Clearinghouse for Federal Scientific \& Technical Information

1970 National Technical Information Service 


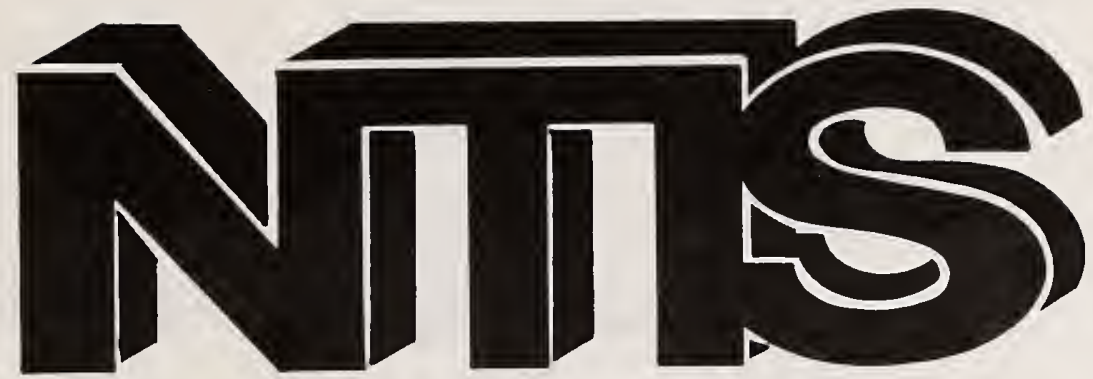

\section{FOREIGN TECHNOLOGY PROGRAM}

\section{PROJECT PLAN}

- Identify Needs

- Identify Sources

- Acquire Information

- Translate

- Disseminate Information 


\section{ACQUISITION APPROACHES}

- U.S. Government Agencies

- Government-to-Government Agreements

- NTIS Cooperating Agencies

- In-country Acquisition Representatives

\section{NTIS COOPERATING AGENCIES}

$\begin{array}{ll}\text { England } & \text { Italy } \\ \text { Finland } & \text { Japan } \\ \text { France } & \text { South Africa } \\ \text { Israel } & \text { Sweden }\end{array}$

And Over 35 Developing Countries 


\section{PROGRAM HIGHLIGHTS}

- 400,000 Documents in the NTIS Collection

- 21,000 New Foreign Documents Acquired in FY 1984

- 91 Acquisition Agreements with Foreign Organizations; 18 with Japanese Organizations

\section{NTIS INPUT 1984}

(U.S. VS FOREIGN)

Total Input $=75,000$ Documents

\begin{tabular}{cr} 
Foreign & $24 \%$ \\
Domestic & $76 \%$ \\
\hline Total & $100 \%$
\end{tabular}




\section{BEST SELLERS FROM FOREIGN SOURCES}

Japan

- Research \& Development in Japan Awarded the Okochi Memorial Prize

- Study of Accidents Involving Industrial Robots

- Research on the Applications of and Material Resources for Fine Ceramics

- Personal Computers in Japan

South Africa

- Fire and Plastic in Buildings

\section{FOREIGN TECHNOLOGY INFORMATION ACCESSIBILITY}

- Full Text in Paper Copy and Microfiche

- Abstracts in the NTIS Bibliographic Data File on Line Through:

- Bibliographic Retreival Services, Inc.

- Dialog Information Services

- Mead Data Central

- SDC Search Service

- Abstracts Bimonthly in Government Reports Announcements and Index

- Weekly Abstracts for Industry in Foreign Technology Abstract Newsletter 


\section{FOREIGN TECHNOLOGY - AN ABSTRACT NEWSLETTER}

\section{Current Coverage}

- Biomedical Technology

- Civil, Construction, Structural, \& Building Engineering

- Communications

- Computer Technology

- Electro \& Optical Technology

- Energy

- Manufacturing \& Industrial Engineering

- Materials Sciences

- Physical Sciences (Applied)

- Transportation Technology

Coming Addition...

- $\quad$ Mining \& Minerals Technology 


\section{DEMAND RATIOS}

Orders/Japanese Documents

- Energy

0.9

- Physical Sciences

1.3

- Civil, etc., Engineering

1.7

- Manufacturing

1.9

- Biomedical Technology

- Transportation

- Communications

3.9

- Materials Sciences

4.2

- Computer Technology

5.1

- Electro \& Optical Technology

5.5 


\section{Abstracts of Science and Technology in Japan \\ ELECTRONICS AND COMMUNICATIONS}

English-Language Abstracts of Japanese-Language Publications

JOIS

JICST Online Information System

JOIS

- File on Science and Technology

- File on Medical Science in Japan

- File on Current Science and Technology Research In Japan

- File on Government Reports in Japan

- Nikkon Kogyo File on New Technology and Products in Japan 



\section{U.S. Access to Japanese \\ Technical Literature: \\ Electronics and \\ Electrical Engineering}

\section{Visuals}

Name of Session

IV. CURRENT PROGRAMS

C. Commercial Organizations

Name, Affiliation, and Address of Presenter

Mr. Herman Baron

Director, UMI-JTIS and

Mr. Tomoyuki Satoh

Associate Director UMI-JTIS

101 Chesley Drive

Media, PA 19063

Title of Presentation

Japanese Technical Information Service of UMI-JTIS

Number of Visuals

9 
Japanese Scientific and Technical Periodicals Indexed and Not Indexed by Western Sources

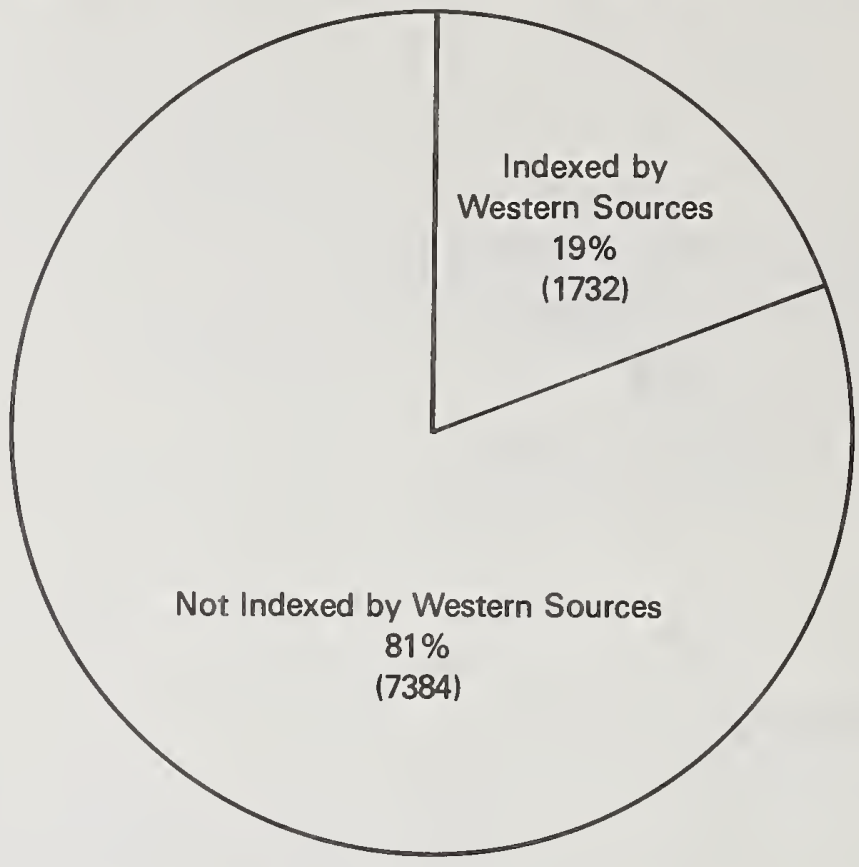

Japanese Scientific and Technical Periodicals Not Indexed by Western Sources (by Subject)
Japanese Scientific and Technical Periodicals Not Indexed by Western Sources (by Language)
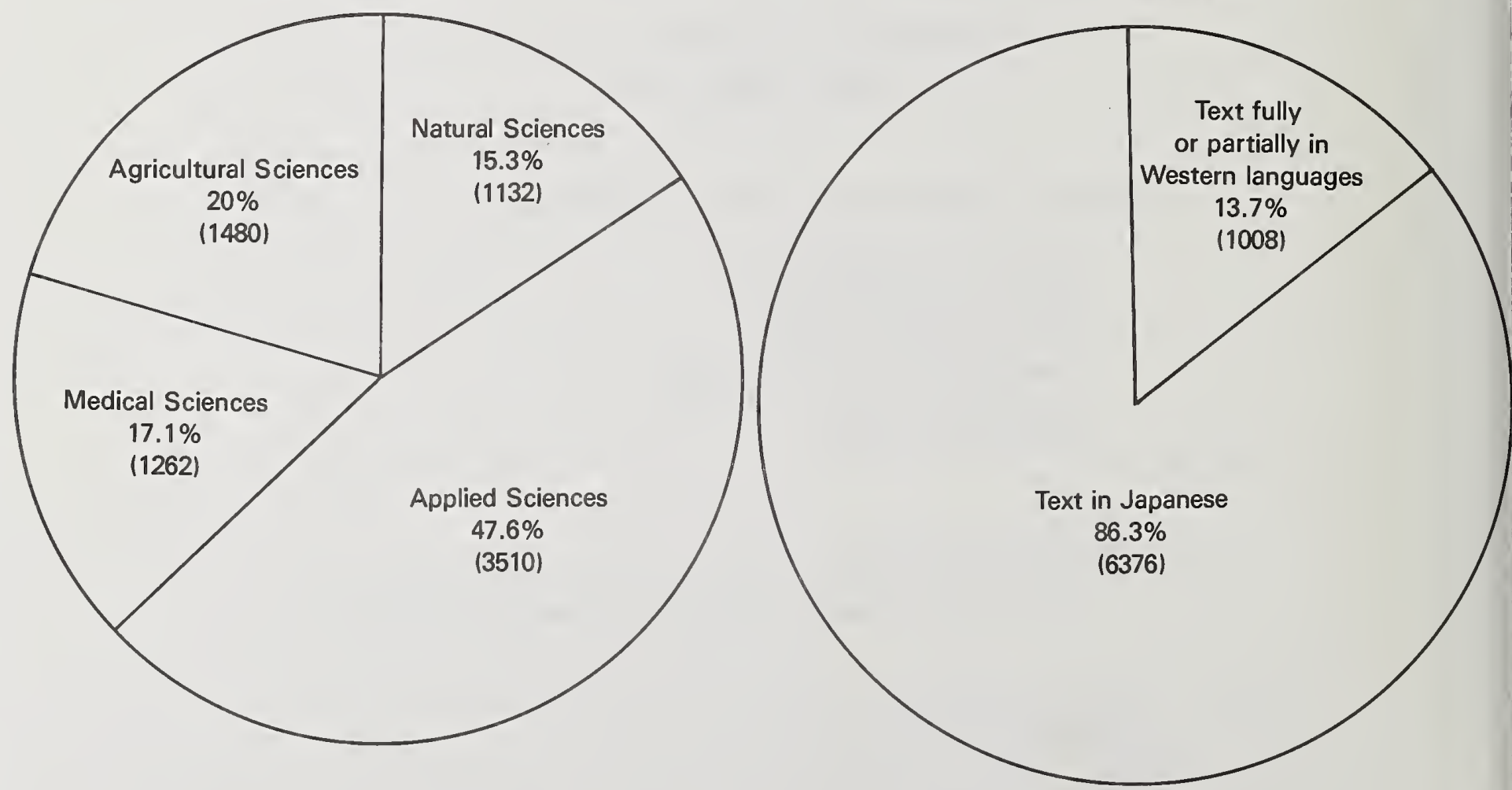

Source: Gibson and Kunkel: Japanese Scientific and Technical Literature: A Subject Guide. Westport, Ct: Greenwood Press, 1981. 


\section{Japanese Scientific and Technical Periodicals \\ Not Indexed by Western Sources \\ (by Subject and Language)}

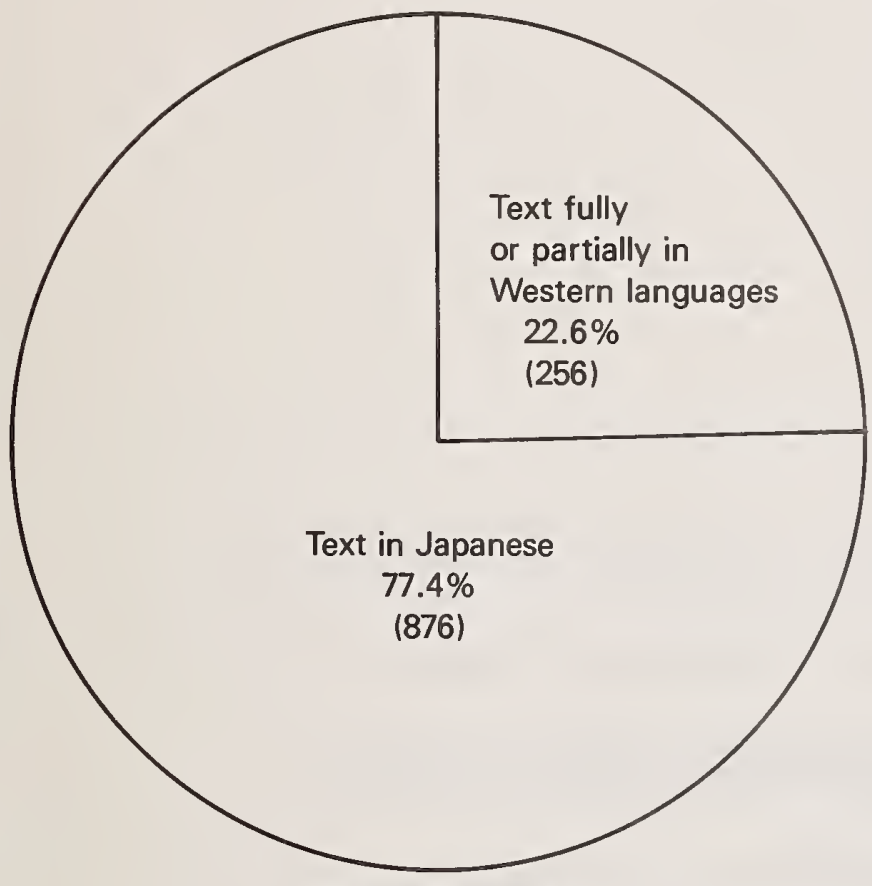

Natural Sciences

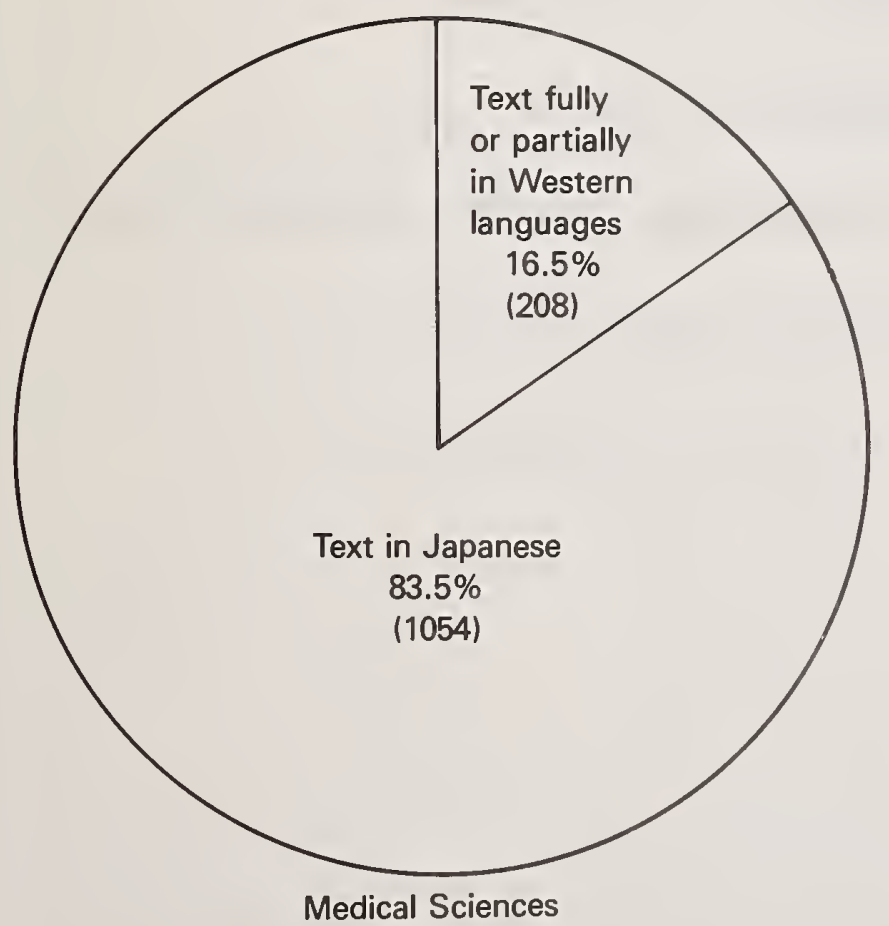

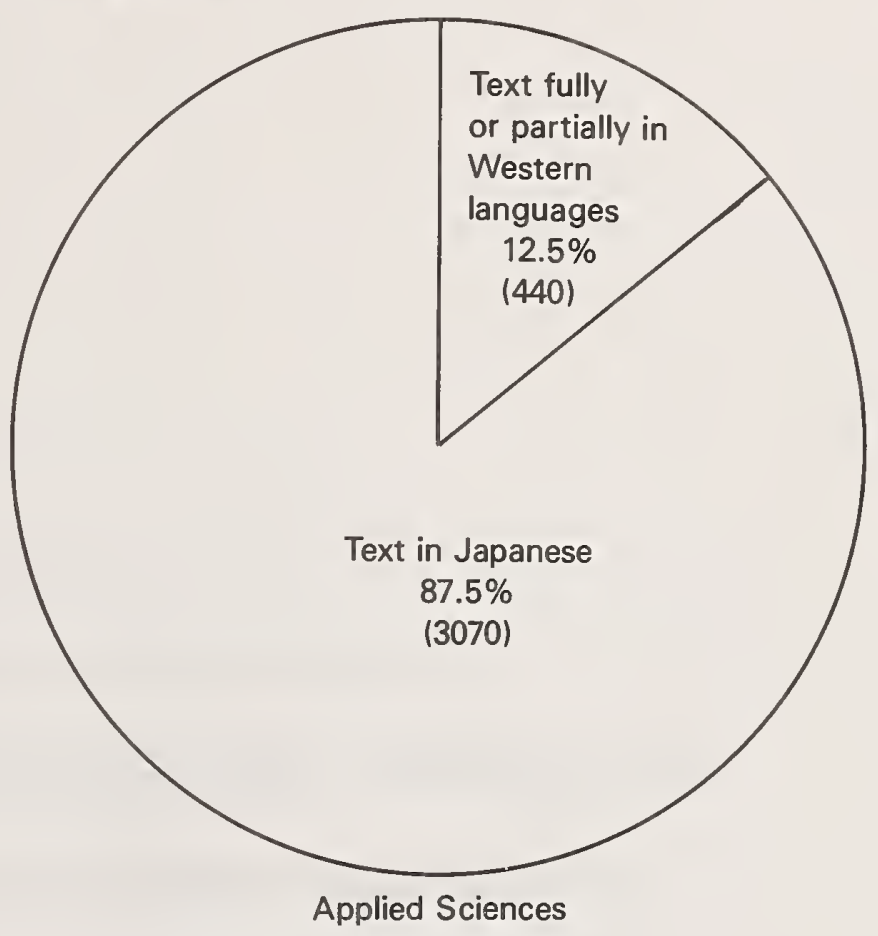

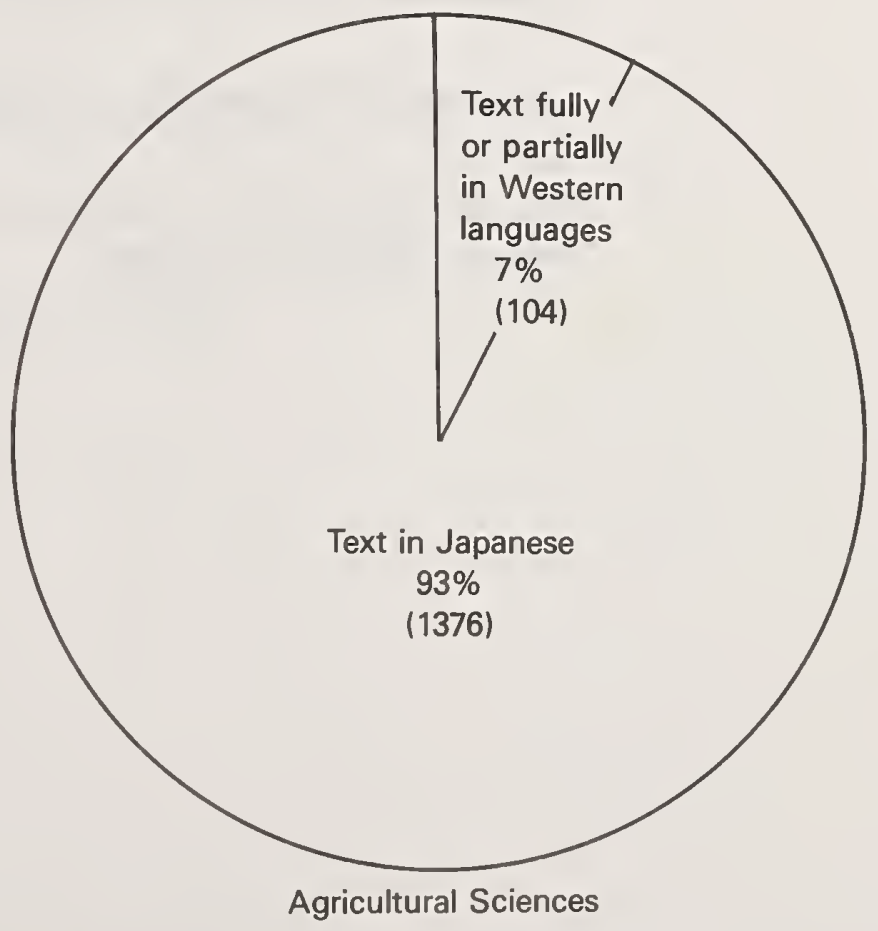

Agricultural Sciences

Source: Gibson and Kunkel: Japanese Scientific and Technical Literature: A Subject Guide. Westport, Ct: Greenwood Press, 1981. 
UMI JAPANESE TECHNICAL INFORMATION SERVICE (JTIS)

- Japanese Technical Abstracts (JTA)

- Japanese Technical Indexes (JTI)

- Japanese Current Research (JCR)

- Most Information Supplied in English by JTIS Not Available Through Other Western Sources. 


\section{JAPANESE TECHNICAL ABSTRACTS}

- English Source of Technical Literature of Japan

- Input: 750 Japanese Technical Journals

- Journals Selected by Panel of Experts in Japan and USA

- Cover-to-Cover Abstracting

- 5000 Concise English Abstracts Monthly

- 100 Bilingual Abstracts

- Technical Skills in Appropriate Fields

- Currentness: Time Lag-3 Months 


\section{PRIMARY SUBJECT AREAS OF JTIS}

- Automation Technology and Robotics

- Biotechnology

- Business Management

- Computers

- Electrical Engineering

- Electronics

- Information Processing

- Instrumentation

- Mathematical Science

- Operations Management

- Photo-Optical Technology

- Quality Control

- Telecommunications 


\section{ANATOMY OF A JTA ABSTRACT}

435, Next Generation VLSI Manufacturing Machines

Kitayama, Toyoki, et al. (NTT. Atsugi Lab.) Denshi Zairyo

24(3): 22-25, Mar. 1985

A Brief Overview of the Lithography Technologies for the Manufacture of $1 \mathrm{M}-4 \mathrm{M}$ Bit DRAMs. Electron-Beam (EB) Etching and X-Ray Etching Technologies Are Mentioned as the Most Promising Technologies.

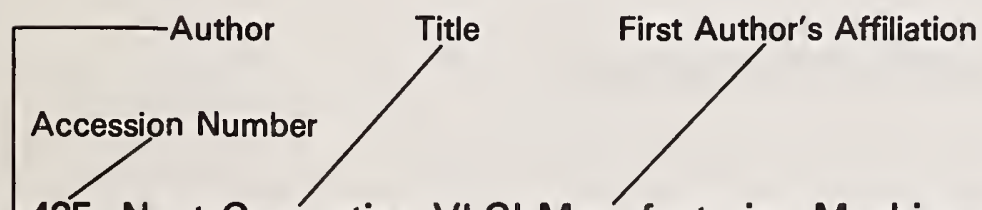

435, Next Generation VLSI Manufacturing Machines

Kitayama, Toyoki, et al. (NTT. Atsugi Lab.) Denshi Zairyo 24(3): 22-25, Mar. 1985

A Brief Overview of the Lithography Technologies for the Manufacture of 1M-4M Bit DRAMs. Electron-Beam (EB) Etching and X-Ray Etching Technologies Are Mentioned as the Most Promising Technologies.

Volume/No.

Month/Year of Publication

Inclusive Pages

Name of Journal 
INDEXES (JTI)

- Each Index Issuie in 3 Sections: Author, Subject, Affiliation

- One Index Issue Monthly

- Index Issues Cumulative

- Latest Information in Bold-Face Type

- Final Index for a Volume Hard-Bound

JAPANESE CURRENT RESEARCH (JCR)

- Compilation of Contents of Abstracted Journals

- One Issue per Month

- Companion of JTA and JTI

- Purpose: Ease of Accesses to JTA and JTI 
JTIS

- Starting of Services Late in 1985

- Previous JTIS Details Tentative 


\section{U.S. Access to Japanese}

\section{Technical Literature:}

Electronics and

Electrical Engineering

\section{Visuals}

Name of Session

IV. CURRENT PROGRAMS

C. Commercial Organizations

Name, Affiliation, and Address of Presenter

Dr. Tony Armstrong

Director, Japanese Technology Evaluation Program Science Applications International Corp.

1200 Prospect

LaJolla, CA 92037

Title of Presentation

Science Applications, Inc.

Number of Visuals 12 
JAPANESE TECHNOLOGY EVALUATION PROGRAM (JTECH)

PRESENTATION TO:

NBS-IEEE SEMINAR

ON

ACCESS TO JAPANESE TECHNICAL INFORMATION

PRESENTATION BY:

TONY W. ARMSTRONG

SCIENCE APPLICATIONS INTERNATIONAL CORPORATION

LA JOLLA, CA

JUNE 25, 1985

- SUMMARY OF JTECH PROGRAM

- $\quad$ LITERATURE APPROACH/EXPERIENCE 
JTECH PROGRAM STAFF

- SAIC PROGRAM DIRECTOR TONY ARMSTRONG

- SCIENCE COORDINATOR GEORGE GAMOTA

- LITERATURE YOUNG KIM

\section{PROGRAM OBJECTIVES}

- PROVIDE TECHNICAL ASSESSMENTS OF EMERGING JAPANESE THRUSTS IN SELECTED HIGH-TECHNOLOGY AREAS

- FOCUS: LONG-TERM TRENDS OF JAPANESE R\&D 


\section{APPROACH}

- ASSESSMENTS PERFORMED BY U.S. TECHNICAL EXPERTS

- SAIC ROLE:

- ORGANIZE PANELS

- COORDINATE PANEL ACTIVITIES

- LITERATURE/TRANSLATION SUPPORT

-REPORT PREPARATION

- BACKGROUND

- EVOLUTION OF THE STATE-OF-THE-ART

-KEY PLAYERS (GOVERNMENT, INDUSTRY, UNIVERSITIES)

-KEY INFORMATION SOURCES

- $\quad$ STATUS OF JAPANESE R\&D

- TREND AND FUTURE DIRECTION OF JAPANESE R\&D

- POTENTIAL SURPRISES AND BREAKTHROUGHS

- comparative U.S. EFFORTS

- SPECIAL JAPANESE FACTORS AND POlicies

- EXPECTED COMMERCIAL IMPACT OF JAPANESE R\&D ON U.S. INDUSTRY

- CONCLUSIONS AND RECOMMENDATIONS 


\section{JTECH PROGRAM STATUS}

- PHASE I (DoC/NSF)

COMPUTER SCIENCE

MECHATRONICS

NON-SILICONE OPTO/MICRO-ELECTRONICS

BIOTECHNOLOGY

- PHASE II (NSF/DARPA)

TELECOMMUNICATION HARDWARE

ADVANCED MATERIALS

SIXTH-GENERATION COMPUTER TECHNOLOGY

("SUMMARY" REPORT)

- APPROACH

- SELECTIVE

- ITERATIVE

- General PROCEDURE

- INITIALLY, GENERAL SOURCE MATERIAL PROVIDED

-PANELISTS IDENTIFY MATERIAL NEEDED IN SPECIAL TECHNICAL AREAS

- JTECH STAFF COLLECTS, EVALUATES, TRANSLATES SOURCE MATERIAL 


\section{CATEGORIES OF SOURCE MATERIAL}

A. GENERAL

-OVERVIEWS, MAINLY IN ENGLISH

B. OPEN

-REGULARLY PUBLISHED TECHNICAL JOURNALS

C. SEMI-OPEN (JTECH EMPHASIS)

-ACADEMIC SOCIETY MEETINGS

- AD HOC TECHNICAL SEMINARS

- NATIONAL PRODUCT TECHNICAL COMMITTEES

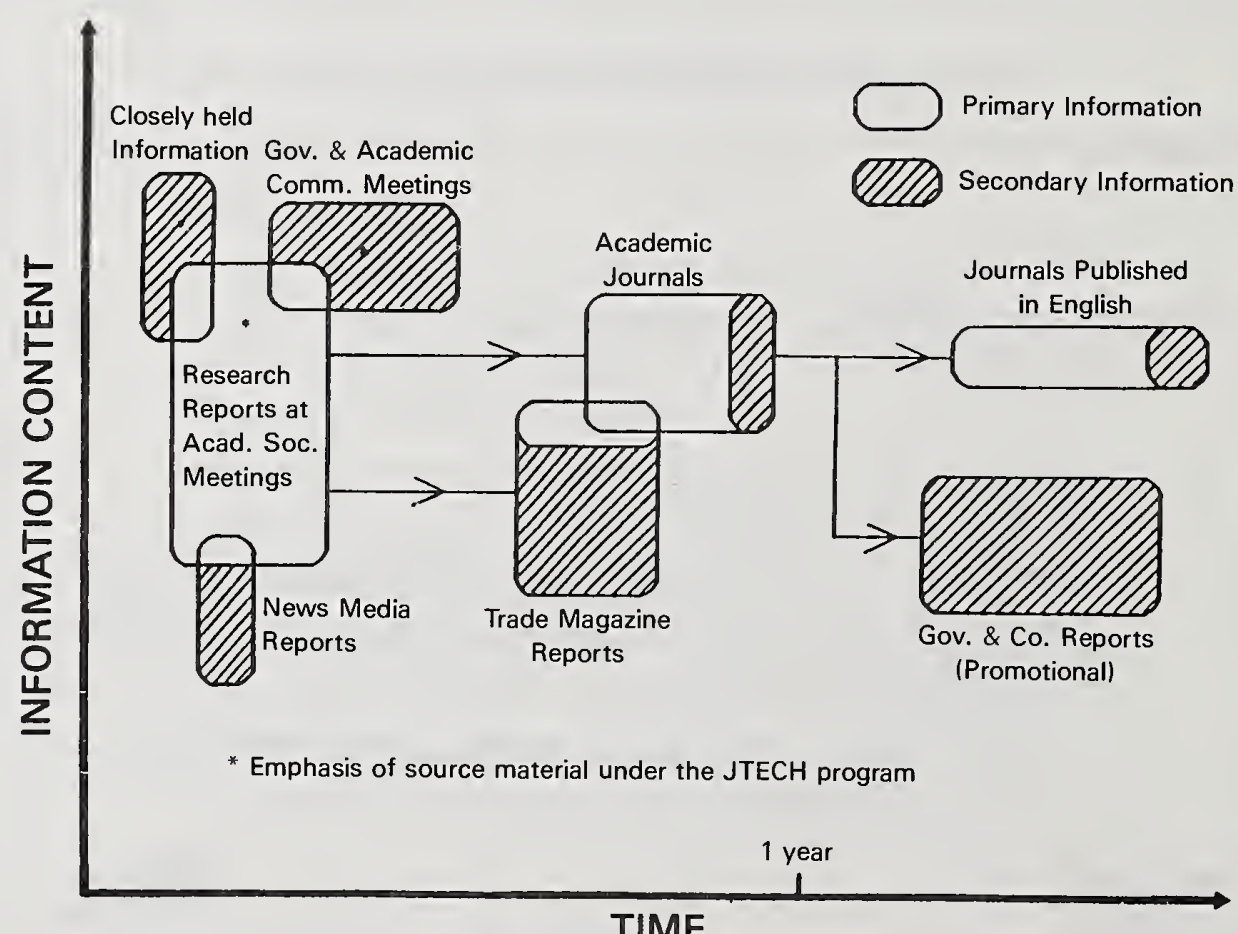

TIME 


\section{"SELECTIVITY" OF TRANSLATION}

- APPROACH

-TRANSLATE/DISTRIBUTE TITLES

-TRANSLATE ABSTRACTS OF "INTERESTING" TITLES (BY PHONE)

-TRANSLATE FULL PAPERS BASED ON ABSTRACTS

- Result

-ABOUT 10\% OF COLLECTED SOURCE MATERIAL IS TRANSLATED

- ESTABLISH MECHANISM OF MONITORING SEMI-OPEN SOURCES

- BROADER DISSEMINATION OF AVAILABLE MATERIAL

- FOR LONGER RANGE, ENCOURAGE STUdYóof JAPANESE LANGUAGE BY U.S. TECHNICAL STUDENTS 


\section{U.S. Access to Japanese Technical Literature: \\ Electronics and Electrical Engineering}

\section{Visuals}

Name of Session

V. MEASURES TO INCREASE TRANSLATION CAPABILITIES

Name, Affiliation, and Address of Presenter

Mr. George W. Rogers, Jr.

Intelligence Community Staff

Washington, DC 20505

Title of Presentation

Machine-Aided Translation

Number of Visuals 1 


\section{ANNOUNCED SPECIFICATIONS OF JAPANESE-ENGLISH TRANSLATION SYSTEMS}

\begin{tabular}{|c|c|c|c|c|c|c|c|}
\hline Manufacturers & Systran & Fujitsu & Hitachi & Bravice & Bravice & NEC & Mitsubishi \\
\hline Names of systems & JESS & Atlas II & Athene N & $\begin{array}{l}\text { Pak } 11 / 73 / 80 \\
\text { Pak } 11 / 73 / 40 \\
\end{array}$ & & PIVOT & \\
\hline $\begin{array}{l}\text { Words in } \\
\text { dictionary }\end{array}$ & 30,000 & $\begin{array}{l}50,000 \text { (basic) } \\
25,000 \text { (S\&T) }\end{array}$ & $\begin{array}{l}10,000 \\
\text { (basic \& } \\
\text { S\&T) }\end{array}$ & $\begin{array}{l}40,000 \\
\text { (basic) }\end{array}$ & 100,000 & $\begin{array}{c}50,000 \\
\text { (basic) } \\
50,000-60,000 \\
\text { (manuals) } \\
20,000-30,000 \\
\text { (glossaries) }\end{array}$ & \\
\hline $\begin{array}{l}\text { Translation speed } \\
\text { (words per hour) }\end{array}$ & 300,000 & 60,000 & 60,000 & $\begin{array}{c}3,000 \\
(73 / 80) \\
2,000 \\
(73 / 40) \\
\end{array}$ & $\begin{array}{l}60,000- \\
80,000\end{array}$ & 100,000 & 20,000 \\
\hline $\begin{array}{l}\text { Accompanying } \\
\text { computers }\end{array}$ & $\begin{array}{l}\text { Mid-range } \\
\text { IBM }\end{array}$ & $\begin{array}{l}\text { FACOM M } 430 R \\
\text { FACOM M } 380 \mathrm{H} \\
\text { Mid-range }\end{array}$ & $\begin{array}{l}\text { HITAC M- } \\
280 \mathrm{H} \\
\text { Mid-range }\end{array}$ & $\begin{array}{l}16-\text { bit } \\
\text { mini- } \\
\text { computers }\end{array}$ & $\begin{array}{l}\text { Large } \\
\text { computers }\end{array}$ & $\begin{array}{c}\text { ACOS-6/MVX } \\
-4 / M V P \\
X E \\
\text { Mid-range } \\
\end{array}$ & $\begin{array}{l}\text { Large } \\
\text { computers }\end{array}$ \\
\hline Marketing date & $?$ & June 1985 & & June 1984 & $\begin{array}{c}\text { Early } 1985 \\
?\end{array}$ & Dec 1985 & Fall 1985 \\
\hline
\end{tabular}




\section{U.S. Access to Japanese \\ Technical Literature: \\ Electronics and \\ Electrical Engineering}

\section{Visuals}

Name of Session

V. MEASURES TO INCREASE TRANSLATION CAPABILITIES

Name, Affiliation, and Address of Presenter

Dr. Edward Daub

Professor, General Engineering

University of Wisconsin-Madison

1527 University Ave.

Madison, WI 53706

Title of Presentation

Education for Reading Japanese Technical Literature

Number of Visuals 4 
PROB.\#1: Time to Master Basic Japanese

1 Basic sounds; kana; rōmaji

2 Basic sentence patterns

3 Role of particles

4 Inflection of verbs \& adjectives

5 Verb-following expressions

6 Embedded relative clauses

7 Kan-Ei jiten; radicals; no. of stroke 
PROB.\#2: Recognizing that Technical J. is Easier than

Conversational Japanese Other Written Japanese

1 Many topics disappear - masu forms keigo

Counters

contractions

(-tte, - chau, ...)

2 No need to generate sentences

$3{ }^{\text {No aural compre- }} \begin{gathered}\text { hension } \\ \text { hen }\end{gathered}$
1 One-to-one corresponc ence of technical word

2 No literary ambiguity

3 Fewer grammatical constructions

4 More limited set of high-frequency kanji needed 


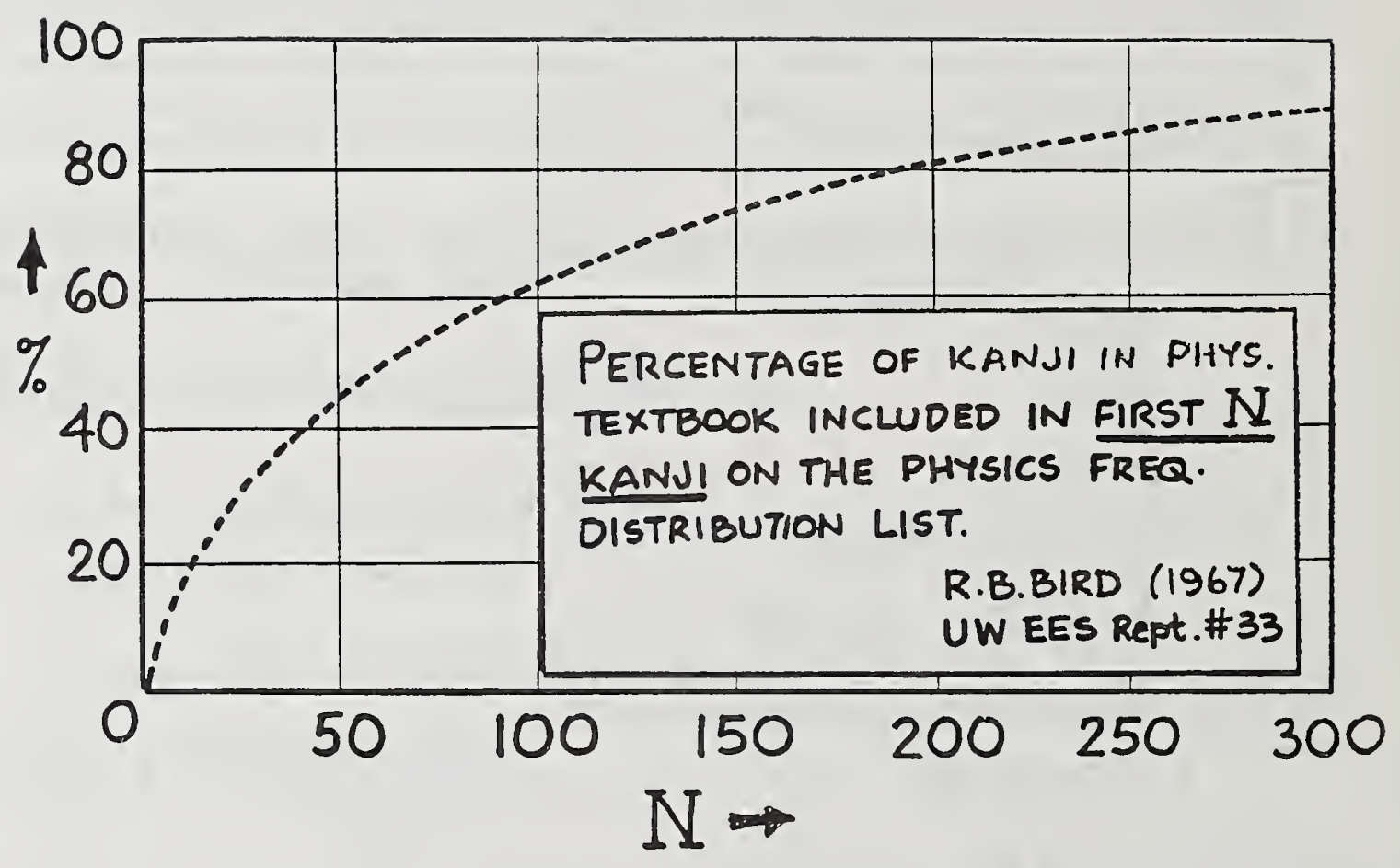




\section{PROB.\# 3: Need for Special Tehg. Matls. for Tech.J.}

- strategy and structure of "C.T.J."

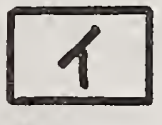

20 kanji emphasized in each lesson

口 Vocabulary for main reading selection

1) Reading selection and translation

Explanatory notes for main reading

木 Construction examples

Supplementary readings $w$. vocabulary

F Final translation test 
NBS.114A (REV. 2.80)

U.S. DEPT. OF COMM.

BIBLIOGRAPHIC DATA

SHEET (See instructions)
1. PUBLICATION OR
REPORT NO. NBS $/ S P-710$
2. Performing Organ. Report No. 3. Publication Date

January 1.986

4. TITLE AND SUBTITLE

U.S. Access to Japanese Technical Literature: Elecironics and Electrical

Engineerir.g

Proceedings of a Seminar

5. $\operatorname{AUTHOR}(S)$

Editor: Edward L. Brady

6. PERFORMING ORGANIZATION (If joint or other than NBS, see instructions)

7. Contract/Grant No.

NATIONAL BUREAU OF STANDARDS

DEPARTMENT OF COMMERCE

Gaithersburg, MD 20899

8. Type of Report \& Period Covered Final

9. SPONSORHG ORGANIZATION NAIIE AND CCMPLETE ADORESS (Street, City, Stote, ZIf)

National Bureau of Standards

Department of Commerce

Gaithersburg, MD 20899

The Institute of Electrical and Electronics

Engineers, Inc.

345 East 47 th Street

New York, NY 10017-2394

10. SUPPLEMENTARY NOTES

Library of Congress Catalog Card Number 85-600637

Document describes a computer program; SF-185, FIPS Software Summary, is attached.

11. ABSTRACT (A 200-word or less factual summary of most significant information. If document includes a significant bibliography or literature survey. mention it here)

On June 24-25, 1985, NBS and IEFE cosponsored a seminar at NBS to examine the need for improved access to Japanese technical information and to explore possible approaches to satisfy those needs. To limit the discussion to practical dimensions, the technical subject matter was restricted to electrical and electronics engineering. The program was designed to provide an opportunity for individuals representing Congress, the practicing engineering community, industry, and the educational community to voice their concerns and their needs. This proceedings volume contains selected presentations made at the seminar plus the visual aids used by each speaker.

12. KEY WORDS (Six to twelve entries; alphabetical order: capitalize only proper names; and separate key words by semicolons) Japanese technical information; Japanese technology; translations of Japanese reports

13. AVAILABILITY

[Xnlimited

$\square$ For Official Distribution. Do Not Release to NTIS

[X] Order From Superintendent of Documents, U.S. Government Printing Office, Washington, D.C. 20402.

[] Order From National Technical Intormation Service (NIIS), Springfield, VA. 2216i
14. NO. OF PRINTED PAGES

155

15. Price 


\section{Periodical}

Journal of Research-The Journal of Research of the National Bureau of Standards reports NBS research and development in those disciplines of the physical and engineering sciences in which the Bureau is active. These include physics, chemistry, engineering, mathematics, and computer sciences. Papers cover a broad range of subjects, with major emphasis on measurement methodology and the basic technology underlying standardization. Also included from time to time are survey articles on topics closely related to the Bureau's technical and scientific programs. Issued six times a year.

\section{Nonperiodicals}

Monographs-Major contributions to the technical literature on various subjects related to the Bureau's scientific and technical activities.

Handbooks-Recommended codes of engineering and industrial practice (including safety codes) developed in cooperation with interested industries, professional organizations, and regulatory bodies.

Special Publications-Include proceedings of conferences sponsored by NBS, NBS annual reports, and other special publications appropriate to this grouping such as wall charts, pocket cards, and bibliographies.

Applied Mathematics Series-Mathematical tables, manuals, and studies of special interest to physicists, engineers, chemists, biologists, mathematicians, computer programmers, and others engaged in scientific and technical work.

National Standard Reference Data Series-Provides quantitative data on the physical and chemical properties of materials, compiled from the world's literature and critically evaluated. Developed under a worldwide program coordinated by NBS under the authority of the National Standard Data Act (Public Law 90-396).

NOTE: The Journal of Physical and Chemical Reference Data (JPCRD) is published quarterly for NBS by the American Chemical Society (ACS) and the American Institute of Physics (AIP). Subscriptions, reprints, and supplements are available from ACS, 1155 Sixteenth St., NW, Washington, DC 20056.

Building Science Series-Disseminates technical information developed at the Bureau on building materials, components, systems, and whole structures. The series presents research results, test methods, and performance criteria related to the structural and environmental functions and the durability and safety characteristics of building elements and systems.

Technical Notes-Studies or reports which are complete in themselves but restrictive in their treatment of a subject. Analogous to monographs but not so comprehensive in scope or definitive in treatment of the subject area. Often serve as a vehicle for final reports of work performed at NBS under the sponsorship of other government agencies.

Voluntary Product Standards-Developed under procedures published by the Department of Commerce in Part 10, Title 15, of the Code of Federal Regulations. The standards establish nationally recognized requirements for products, and provide all concerned interests with a basis for common understanding of the characteristics of the products. NBS administers this program as a supplement to the activities of the private sector standardizing organizations.

Consumer Information Series-Practical information, based on NBS research and experience, covering areas of interest to the consumer. Easily understandable language and illustrations provide useful background knowledge for shopping in today's technological marketplace.

Order the above NBS publications from: Superintendent of Documents, Government Printing Office, Washington, DC 20402.

Order the following NBS publications-FIPS and NBSIR's-from the National Technical Information Service, Springfield, VA 22161.

Federal Information Processing Standards Publications (FIPS PUB)-Publications in this series collectively constitute the Federal Information Processing Standards Register. The Register serves as the official source of information in the Federal Government regarding standards issued by NBS pursuant to the Federal Property and Administrative Services Act of 1949 as amended, Public Law 89-306 (79 Stat. 1127), and as implemented by Executive Order 11717 (38 FR 12315, dated May 11, 1973) and Part 6 of Title 15 CFR (Code-of Federal Regulations).

NBS Interagency Reports (NBSIR)-A special series of interim or final reports on work performed by NBS for outside sponsors (both government and non-government). In general, initial distribution is handled by the sponsor; public distribution is by the National Technical Information Service, Springfield, VA 22161, in paper copy or microfiche form. 
U.S. Department of Commerce National Bureau of Standards

Gaithersburg, MD 20899

Official Business

Penalty for Private Use $\$ 300$ 